Georgetown University Law Center

Scholarship @ GEORGETOWN LAW

1989

\title{
Constitutional Bait and Switch: Executive Reinterpretation of Arms Control Treaties
}

David A. Koplow

Georgetown University Law Center, koplow@law.georgetown.edu

This paper can be downloaded free of charge from:

https://scholarship.law.georgetown.edu/facpub/1741

137 U. Pa. L. Rev. 1353

This open-access article is brought to you by the Georgetown Law Library. Posted with permission of the author. Follow this and additional works at: https://scholarship.law.georgetown.edu/facpub

Part of the Constitutional Law Commons, International Law Commons, and the National Security Law Commons 


\section{ARTICLE}

CONSTITUTIONAL BAIT AND SWITCH:

EXEGUTIVE REINTERPRETATION OF ARMS CONTROL TREATIES

DAVID A. Koplow $†$

Table of Contents

IntRoduction $\ldots \ldots \ldots \ldots \ldots \ldots \ldots \ldots \ldots \ldots . \ldots \ldots$

I. Factual Background: Four Gase Studies of Arms Control Treaties . . . . . . . . . . . . . 1358

A. The Geneva Protocol on Chemical Warfare .... 1359

B. The SALT I Interim Agreement on Strategic Offensive Arms ..................... 1362

C. The ABM Treaty ................ 1366

1. Substance of the Reinterpretation Issue ..... 1370

2. Process of the Reinterpretation Issue ...... 1373

D. The INF Treaty ................... 1375

II. Applicable Principles of International and Constitutional Law .................. 1380

A. International Law Principles ............ 1381

1. State sovereignty requires that the treaty that binds is the treaty that was negotiated and ratified. ................... 1381

2. Treaties are to be interpreted in good faith. . 1383

3. The critical time for measuring the parties' intentions and understandings is the time at which the treaty is made. ............ 1386

4. International law contemplates a variety of treaty-making processes. . . . . . 1387

+ Professor of Law, Georgetown University Law Center. During the spring and summer of 1988, an earlier version of this study was the focus of the Special Working Committee on Legal Aspects of Current Issues of Arms Control and Disarmament Policy of the American Society of International Law. The author gratefully acknowledges the contributions of that Committee and the expertise and insights of its members. 
B. Constitutional Principles of Treaty Interpretation

1. The Supremacy Clause establishes that treaties and statutes are equivalent under the Constitution.

2. There is a substantial, although not complete, deference to the Executive in matters of international policy.

a. Shaping Treaties .............. 1394

b. Interpreting Treaties . . . . . . . . . . . 1396

3. The Senate has a variety of mechanisms for establishing its interpretation of a treaty.

1401

4. The critical moment for measuring the intentions of the Congress and the Executive is the time at which the treaty is made.

5. Strict mutuality of treaty obligations is unlikely and legally unnecessary.

III. APplying the LAw to the Facts ............ 1413

A. Scenarios of Treaty Interpretation ......... 1413

1. Knowing Misrepresentation ............ 1413

2. Subsequent Alteration ............. 1414

3. "Glear Unclarity" . . . . . . . . . . . . . . . . 1414

4. Unforeseen Ambiguity ................ 1414

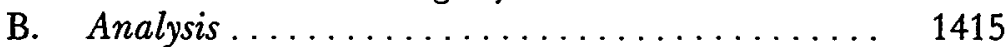

1. International Law ................ 1415

2. Constitutional Law ................. 1416

C. When Is a Treaty Interpretation "Entrenched" into Law? ............................ 1418

1. What did the Senate say about the particular issue when providing its advice and consent to the treaty?

2. What was said to the Senate, creating an understanding of the treaty, prior to ratification?

3. What has been the attitude of the other party to the competing interpretations of the treaty?

4. How much support is there in the treaty text and record for the two interpretations? .....

5. What is the record of "subsequent practice" of

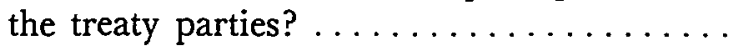

6. How different is the new interpretation from the old?

7. Does the new interpretation purport to create new obligations, or to release old ones?..... 
8. Are there any changed circumstances that affect the treaty?................. 1425

IV. RECOMmENDATIONS AND CoNCLUSIONS .......... 1425

A. Unilateral Modifications in the Meaning of United States Treaty Obligations Should Not Be

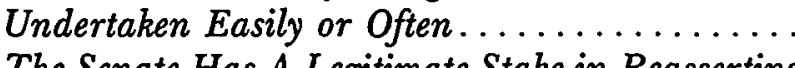

B. The Senate Has A Legitimate Stake in Reasserting Its Role in Creating Treaties .............

C. The Process of Creating National Security Treaties Should Not Be Burdened Any More Than It Already Is . . . . . . . . . . . . . . . . . . .

D. In Establishing an Authoritative Interpretation of a Treaty for Purposes of Domestic Law, the United States Should Not Overlook the Possibility of Authoritative International Adjudication ....

E. Summation .......................

\section{INTRODUCTION}

A new constitutional crisis has been thrust upon the American body politic. ${ }^{1}$ The crisis arises from a dispute concerning the allocation of legal authority for the interpretation, and especially for the reinterpretation, of international agreements. ${ }^{2}$ Once a sleepy backwater reserved for specialized scholars, ${ }^{3}$ the issue of treaty interpretation has

1 See The ABM Treaty and the Constitution: Joint Hearings Before the Senate Comm. on Foreign Relations and the Senate Comm. on the Judiciary, 100th Cong., 1st Sess. 2-3, 197 (1987) [hereinafter Joint Hearings] (statement of Senator Biden); id. at 54 (statement of Senator Nunn). But see id. at 112, 444-45 (statement of Senator Hollings) (suggesting that the ABM Treaty reinterpretation issue is not a "constitutional crisis"); id. at 123 (statement of Abraham D. Sofaer, State Department Legal Adviser) (same).

2 Unlike domestic United States law, international law generally does not differentiate between "treaties" and "other international agreements." See Vienna Convention on the Law of Treaties, opened for signature May 23, 1969, art. 2, para. 1(a), reprinted in 63 AM. J. INT'L L. 875, 876 (1969) [hereinafter Vienna Convention]; Congressional Research Service Study for the Senate Comm. on Foreign Relations, 98Th Cong., 2D Sess., Treaties and Other International Agreements: The Role of the United States Senate 60 (Comm. Print 1984) [hereinafter Role of the Senate]; Restatement (Third) of the Foreign Relations LAW OF THE UNITED StaTes $\S \S 301,303$ (1987) [hereinafter Restatement].

This Article will use the term "treaty" to refer to either type of international agreement, unless the context indicates otherwise. $C f$. Weinberger v. Rossi, 456 U.S. 25,36 (1982) (holding that statutory reference to "treaty" embraces executive agreements as well as Article II treaties).

3 See Joint Hearings, supra note 1, at 317 (statement of Professor Louis Henkin) (noting that the treaty clause of the Constitution has "not been a source of serious controversy during the two centuries of our national life under the Constitution"). 
drawn the President and Congress into stark confrontation ${ }^{4}$ and generated splashy headlines. ${ }^{\mathrm{s}}$

This attention and furor are well-deserved. The clash over treaty interpretation powers is no mere lawyers' debate concerning the intentions of the Constitution's Framers. ${ }^{6}$ It directly affects the implementation of international obligations shaping the national security of the United States. In particular, the 1972 Treaty on Anti-Ballistic Missile Systems ("ABM Treaty") ${ }^{7}$ and the 1987 Treaty on Intermediate-range Nuclear Forces ("INF Treaty") have been embroiled in an attempt by the Executive to reserve the right unilaterally to reinterpret treaties. What is immediately at stake in executive reinterpretation has been a threat to gut the central purposes of the ABM Treaty and to abort the nascent INF Treaty. Unless corrected, attempts by the Executive to usurp treaty reinterpretation power will, in the longer term, undermine United States arms control policies, jeopardize future Strategic Arms Reduction Talks ("START") agreements, and weaken the security of the international community.

These circumstances prompt reevaluation of three questions that

- See Senate Comm. on Foreign Relations, The ABM Treaty InterpreTation Resolution, S. ReP. No. 164, 100th Cong., 1st Sess. 66 (1987) [hereinafter 1987 SFRC REPORT] (stating that "the Reagan Administration's 'reinterpretation' of the ABM Treaty constitutes the most flagrant abuse of the Constitution's treaty power in 200 years of American history").

- See Norman, Showdown Nears on ABM Treaty, 238 ScIEnce 147 (1987); Smith, When Treaty Interpretations Differ, Who Has the Last Word?, Wash. Post, Feb. 17, 1988, at A17, col. 1; Gordon, Within the Arms Debate, a $2 d$ Debate, N. Y. Times, Feb. 9, 1988, at A3, col. 1.

Legal scholars have also looked at the reinterpretation question. See Chayes \& Chayes, Testing and Development of "Exotic" Systems Under the ABM Treaty: The Great Reinterpretation Caper, 99 HARv. L. REv. 1956 (1986); Kennedy, Treaty Interpretation by the Executive Branch: The ABM Treaty and "Star Wars" Testing and Development, 80 AM. J. INT'L L. 854 (1986); Klema, Strategic Defense Initiative and the New Interpretation of the ABM Treaty, 10 ASILS INT'L L.J. 149 (1986); Sherr, Sound Legal Reasoning or Policy Expedient?, 11 INT'L SECURITY 71 (Winter 198687).

- See, e.g., Joint Hearings, supra note 1, at 263 (statement of Senator Biden) ("IW]hat is at issue here is decidedly not a lawyers" quarrel. We are witnessing a major assault on the premises and structure of a national nuclear strategy. . . [and] a subtle but equally significant assault on the Constitution's allocation of the treaty power."); 1987 SFRC REPORT, supra note 4, at 46-47 ("The issue may appear . . . to be nothing more than a technical dispute . . . - a lawyers' quarrel. But it is far more than that, in both substance and constitutional significance.").

7 Treaty on the Limitation of Anti-Ballistic Missile Systems, May 26, 1972, United States-USSR, 23 U.S.T. 3435, T.I.A.S. No. 7503 [hereinafter ABM Treaty].

8 Treaty on the Elimination of Intermediate-range and Shorter-range Missiles, Dec. 8, 1987, United States-USSR, 23 WeEkLy ComP. Pres. Doc. 1459 [hereinafter INF Treaty]; see also Senate Comm. on Foreign Relations, The INF Treaty, S. EXEC. REP. No. 15, 100th Cong., 2d Sess. (1988) [hereinafter INFT REPORT] (analyzing the meaning and impact of the INF Treaty). 
are fundamental to the domestic and international law of treaties: (1) What are the respective roles of Congress and the President in creating international legal obligations for the United States? (2) How is authority for interpreting international agreements divided among the three branches of the federal government? and, of the most pressing immediate concern, (3) Under what circumstances may the Executive Branch "reinterpret" a treaty that previously has received an authoritative national meaning?

This Article refutes the rationale put forth by the Executive Branch, known as the Sofaer Doctrine, which purports to provide a legal foundation for the Executive's claim to powers of reinterpretation. ${ }^{9}$ After demonstrating that assertions of unilateral reinterpretation powers are unconstitutional and violate international law, I offer an alternative jurisprudential model. ${ }^{10}$ This alternative derives from the thesis that the power to create treaty obligations for the United States is shared between the Executive and Legislative Branches. Once an interpretation of a treaty has become entrenched in United States domestic law through the joint action of the Senate and President, it cannot be altered unilaterally by a reinterpretation sponsored by either branch alone. ${ }^{11}$

On occasion it may be difficult to ascertain whether a particular interpretation has, in fact, become entrenched as a necessary part of United States law. Nevertheless, the principle of durability, and its application to current and future interpretation controversies are clear: The Executive's attempt to reinterpret established aspects of a treaty is an unconstitutional usurpation of power. This conclusion is supported by a three part analysis.

Part I is primarily historical. It offers concrete examples of reinterpretation disputes that underscore the importance of the current debate, and provide a factual base for subsequent legal discussion. Four major instances of prior clashes between Congress and the Executive over treaty interpretation are described: 1) the Geneva Protocol on chemical weapons, ${ }^{12}$ which sparked controversy over the legal status of

- See infra notes $245-48$ and accompanying text.

10 See infra notes 249-69 and accompanying text.

11 Conversely, where no authoritative interpretation under United States law has been established for the treaty, each branch of the federal government may proceed, pursuant to its own law-making operations, to derive meaning from the ambiguous or controversial passages. This process of initial interpretation cannot effectively impose a fixed meaning for the treaty that binds other branches of the United States government.

12 Protocol for the Prohibition of the Use in War of Asphyxiating, Poisonous or Other Gases, and of Bacteriological Methods of Warfare, opened for signature June 17, 1925, 26 U.S.T. 571, T.I.A.S. No. 8061, 94 L.N.T.S. 65 [hereinafter Geneva Protocol]. 
herbicides and riot-control agents; 2) the SALT I Interim Agreement, ${ }^{13}$ which supplied a problematic definition of "heavy" missiles; 3) the ABM Treaty, which generated a maelstrom of debate concerning its constraints on the legality of the Strategic Defense Initiative; and 4) the INF Treaty, which prompted the most recent arguments regarding the limits on future reinterpretation by the Executive. In Part II, the Article draws principles of treaty interpretation and constitutional prerogatives from both international law and United States constitutional law in order to construct a stable and consistent framework for resolving interpretation disputes. In the process, support is generated for the contention that the Executive's asserted power to reinterpret treaties violates both international law and the United States Constitution.

Part III considers a variety of hypothetical factual scenarios relevant to treaty interpretation. This exercise puts the framework of principles from Part II into practice, and presents a comprehensive model of interpretation. This model offers eight considerations that should serve to resolve many of the ambiguities currently plaguing the interpretation process. Furthermore, the real flexibility it permits avoids the predetermined and sterile exercise that characterizes the Sofaer Doctrine. The process of treaty interpretation will continue to be an inherently complex one using the eight-pronged model, but it need not be as contentious as it has become.

The Article concludes with some observations and recommendations. First, as mandated by both legal and policy imperatives, unilateral modifications in the meaning of United States treaty obligations should not be undertaken easily or often. Second, the Senate has a legitimate stake in reasserting its role in creating treaties. Third, I urge acceptance of the alternative to the Sofaer Doctrine presented here in order to ease the treaty-making process for both the Executive and Congress. The always-uncertain progression of a treaty should not be burdened any more than it already is. Finally, while it is difficult to imagine in the context of a treaty involving arms and the Soviets, I propose that even here, the United States should not overlook the possibility of authoritative international adjudication.

\section{Factual Background:}

Four Case Studies of Arms Control Treaties

The current debate over treaty interpretation is not the first of its

1s Interim Agreement on Certain Measures With Respect to the Limitation of Strategic Offensive Arms, May 26, 1972, United States-USSR, 23 U.S.T. 3462, T.I.A.S. No. 7504 [hereinafter Interim Agreement]. 
kind. In fact, similar controversies regarding other arms control treaties and other administrations foreshadowed today's struggles. A brief study of the background and results of these earlier skirmishes will help place the current debate in the proper context, and will highlight the significance that the Senate places on communications from the Executive in fulfilling its constitutionally mandated role of providing advice and consent.

\section{A. The Geneva Protocol on Chemical and Bacteriological Warfare}

The history of the Geneva Protocol illustrates the importance Congress places on the Executive's representations regarding treaty interpretation. In 1925, the United States signed the Geneva Protocol for the Prohibition of the Use in War of Asphyxiating, Poisonous or Other Gases, and of Bacteriological Methods of Warfare. ${ }^{14}$ The Protocol was limited essentially to a wartime "non-use" agreement and did not prohibit the production and deployment of chemical weapons. ${ }^{15}$ While the Geneva Protocol was ratified by many countries (some adopting restrictive reservations) and entered into force on February $8,1928,{ }^{16}$ it remained unratified by the United States for almost fifty years. ${ }^{17}$

14 See Geneva Protocol, supra note 12; United States Arms Control \& Disarmament Agency, ARms Control and Disarmament Agreements: Texts AND Histories of Negotiations 9 (5th ed. 1982) [hereinafter AGDA TREATY Book]. The Geneva Protocol was one of the earliest modern arms control agreements, growing out of 19th century attempts to regulate chemical weapons. See id. at 3-4; Smith, International Regulation of Chemical and Biological Weapons: "Yellow Rain" and Arms Control, 1984 U. ILL. L. REv. 1011, 1031-32.

${ }_{15}$ See ACDA TREATY Book, supra note 14 , at 9 . The negotiating parties were motivated, in large measure, by the experience of World War I, in which the massive, albeit unsophisticated, use of chemical weapons by both sides resulted in approximately 100,000 fatalities. See Chemical Warfare, Economist, June 4, 1988, at 19, 20. Chemical weapons were perceived as a particularly loathsome form of combat, suited for international prohibition. See Satchell, A Plague of "Hellish Poison," U.S. NEwS \& WORLD REP., Oct. 26, 1987, at 30, 30.

${ }^{16}$ See ACDA TREaty Book, supra note 14, at 14. The Protocol was ratified by all the great powers, except the United States and Japan, before World War II. See id. at 9 . Several nations have deposited reservations limiting the application of the Geneva Protocol to situations of reciprocity, retaining the right to use chemical weapons against a party or non-party who uses them first. See Smith, supra note 14, at 1037-38.

The Geneva Protocol generally was observed throughout World War II, although Italy did use chemical weapons in its Ethiopian campaign. See ACDA TREATY Book, supra note 14, at 9. More recently, there have been reports that Iraq has used chemical weapons in its war with Iran. See Ember, Worldwide Spread of Chemical Arms Receiving Increased Attention, Chemical \& EngIneERING News, Apr. 14, 1986, at 8, 8; see also Pear, U.S. Will Propose Wide U.N. Powers on Chemical Arms, N.Y. Times, Jan. 3, 1989, at A1, col. 6 (noting the Reagan Administration's concern regarding the evidence that Libya was acquiring the means to produce chemical weapons).

17 See ACDA TREATY BooK, supra note 14, at 13 (Protocol signed by President Ford on Jan. 22, 1975). The Senate Foreign Relations Committee favorably reported 
By 1970, the controversy within the United States had narrowed to a question about the scope of the treaty ban: Did the Protocol apply only to lethal chemical agents, or did it also prohibit the use in war of non-toxic riot-control agents and herbicides? ${ }^{\mathbf{1 8}}$ The Nixon Administration maintained that the Treaty had the more limited scope, while the Senate Foreign Relations Committee, like most of the international community, ${ }^{19}$ favored the broader interpretation. ${ }^{20}$

In 1974, the Ford Administration began a new effort to secure Senate consent to the Protocol's ratification. ${ }^{21}$ On December 10, 1974, Dr. Fred Ikle, then Director of the United States Arms Control and Disarmament Agency, testified that the Executive Branch still adhered to its earlier view regarding the appropriate scope of the Treaty, but was prepared, as a matter of national policy, to renounce the first use in war of herbicides and riot-control agents, except for specified circumstances. ${ }^{22}$

the Geneva Protocol in 1926, but it was not brought to a floor vote. President Truman later withdrew the Geneva Protocol from the Senate and it received little notice thereafter. See id. at 10.

18 See id. at 11. Under the narrow construction, in war a party would be allowed to utilize certain non-lethal chemicals of the sort occasionally employed in peacetime to clear vegetation or to quell civil disturbances (such as tear gas or irritant agents). Under the broader view, those applications could continue in peacctime, but could not be introduced as war-fighting measures. See id. at 10.

10 See id. at 10-11; Smith, supra note 14, at 1036.

${ }^{20}$ See ACDA Treaty Book, supra note 14, at 11 . The Nixon Administration resubmitted the Geneva Protocol to the Senate on August 19, 1970, proposing an accompanying reservation reaffirming the position that the Treaty did not prohibit use of riot-control agents and herbicides in war. Senator Fulbright, chair of the Foreign Relations Committee, opposed ratification of the Treaty with the restrictive reservation, and the Committee deferred further action. See id. at 11-12.

${ }^{21}$ The renewed interest in bringing the Geneva Protocol into effect for the United States came in conjunction with the effort to seek Senate advice and consent to the 1972 Biological Weapons Convention. See Convention on the Prohibition of the Development, Production and Stockpiling of Bacteriological (Biological) and Toxin Weapons and on Their Destruction, opened for signature April 10, 1972, 26 U.S.T. 583, T.I.A.S. No. 8062, 1971 U.N. Juridical Yearbook 118 [hereinafter Biological Weapons Convention]; ACDA TREATY Book, supra note 14, at 122.

Under the Biological Weapons Convention, parties undertake not to develop, produce, stockpile or acquire biological agents or toxins, or weapons for their delivery. See Biological Weapons Convention, supra, art. I., 26 U.S.T. at 587, T.I.A.S. No. 8062. The Treaty was negotiated principally by the United States and the Soviet Union, and subsequently was opened for multilateral signature. See ACDA TREATY Book, supra note 14 , at $121-22$.

22 See Prohibition of Chemical and Biological Weapons: Hearings on S.Res. 48 Relating to Comprehensive Interpretation of the Geneva Protocol Before the Senate Comm. on Foreign Relations, 93d Cong., 2d Sess. 12 (1974) [hereinafter 1974 SFRC Hearings]. The Ikle statement reserved the right to use herbicides for the control of vegetation inside United States bases and installations and to use riot control agents in defensive military modes, such as in rescue missions or where enemy troops hide behind civilians as screens. See id. 
The Foreign Relations Committee then favorably reported the Geneva Protocol by a unanimous vote, ${ }^{23}$ attaching particular importance to Dr. Ikle's written response in the following colloquy in connection with his testimony ${ }^{24}$ :

Question .... Assuming the Senate were to give its advice and consent to ratification on the grounds proposed by the Administration, what legal impediment would there be to subsequent Presidential decisions broadening the permissible uses of riot-control agents?

Answer. There would be no formal legal impediment to such a decision. However, the policy which was presented to the Committee will be inextricably linked with the history of Senate consent to ratification of the Protocol with its consent dependent upon its observance. If a future administration should change this policy without Senate consent whether in practice or by a formal policy change, it would be inconsistent with the history of the ratification, and could have extremely grave political repercussions and as a result is extremely unlikely to happen. ${ }^{25}$

The Geneva Protocol was unanimously approved by the Senate on December $16,1974,{ }^{26}$ and ratified by President Ford on January 22, 1975. ${ }^{27}$ United States policy and practice have continued to be consistent with the constraints of the Ikle statement, and the issue of possible derogation of the 1974 policy statement and testimony has, to date, remained latent. ${ }^{28}$ Nonetheless, this example indicates how important

It is noteworthy that in questioning by Senator Church, Ikle testified that the national policy restricting the use of herbicides and riot-control agents should be stated in the report of the Foreign Relations Committee, rather than in an understanding attached to the instrument of ratification, which would be "a more formal step" and possibly "an unnecessary complication." Id. at 17.

${ }^{23}$ See Senate Comm. on Foreign Relations, The Geneva Protocol of 1925, S. Exec. ReP. No. 35, 93d Cong., 2d Sess. 4 (1974). The Administration had recommended adoption of a reservation that would limit the application of the Geneva Protocol to situations of reciprocity - that is, if lethal weapons were used first against United States troops in war, the United States would be legally free to retaliate in kind. See 1974 SFRC Hearings, supra note 22, at 18-19 (statement of Dr. Fred Ikle, Director of Arms Control and Disarmament Agency).

${ }_{24}$ See ACDA Treaty Book, supra note 14, at 12 (noting that the Committee attached particular importance to Ikle's response).

25 1974 SFRC Hearings, supra note 22, at 29.

28 See 120 Cong. Rec. S40,067-68 (daily ed. Dec. 16, 1974).

27 See ACDA TREaty Book, supra note 14, at 13.

${ }^{28}$ President Ford issued an executive order reinforcing the restrictions on the use of chemical weapons. See Exec. Order No. 11,850, 3 C.F.R. 149 (1975), reprinted in 50 U.S.C.A. $\S 1511$, at 225 (West Supp. 1988). 
Congress considers Executive Branch representations regarding the interpretation of a treaty. Indeed, when the national security of the United States is directly involved, the stakes in the battle are enormous.

\section{B. The SALT I Interim Agreement on Strategic Offensive Arms}

SALT I, the first series of United States-USSR Strategic Arms Limitations Talks, ${ }^{29}$ resulted in 1972 in two important international agreements: the ABM Treaty $^{30}$ (discussed below), and the Interim Agreement on Certain Measures With Respect to the Limitation of Strategic Offensive Arms. ${ }^{31}$ The Interim Agreement was intended as a partial, temporary measure, ${ }^{32}$ essentially to "freeze" for five years (pending the negotiation of a more comprehensive accord) the status quo regarding the most important strategic offensive systems. ${ }^{33}$

One of its most important sets of provisions dealt with the issue of "modern heavy" missiles, and the Executive's handling of this topic is instructive for our purposes. In the late 1960s and early 1970s, the United States was particularly concerned with the emerging fleet of So-

${ }^{29}$ See S. Talbott, Endgame: The Inside Story of SALT II 19-24 (1979); T. Wolfe, The SALT Experience 8-14 (1979); ACDA Treaty Book, supra note 14, at 132 .

so See ABM Treaty, supra note 7.

31 See Interim Agreement, supra note 13. The Interim Agreement was approved by Congress on September 30, 1972, in Pub. L. 92-448, 86 Stat. 746 (1972). See generally House Foreign AfFaIRS CoMmitTeE, REPORT ON THE AgREEMENT ON THE Limitation of Strategic Offensive Weapons, H.R. Rep. No. 1324, 92d Cong., 2d Sess. (1972) [hereinafter HFAC REPORT] (report filed with agreement).

${ }^{32}$ See Interim Agreement, supra note 13, arts. I, III \& VIII.2; ACDA TreatY Book, supra note 14, at 148.

ss To cap the superpowers' strategic arsenals under the Interim Agreement, neither side was permitted to begin the construction of additional fixed launchers for Intercontinental Ballistic Missiles ("ICBMs"). Moreover, launchers for SubmarineLaunched Ballistic Missiles ("SLBMs") and SLBM-carrying submarines were limited and could be deployed in greater numbers only if launchers for corresponding older ICBMs were retired. See Interim Agreement, supra note 13, arts. I \& III.

ICBMs are land-based missiles capable of delivering nuclear missiles at ranges of 3,500 miles or more. SLBMs are sea-based missiles capable of similar ranges carried aboard submarines. The Interim Agreement applies to launchers of missiles, rather than the missiles themselves, because the launchers (permanent holes in the ground (called "silos") for fixed ICBMs and vertical submarine tubes for SLBMs) are easier to identify and count by satellite photo reconnaissance, thereby ameliorating the task of verifying compliance with the Treaty's limitations. See N. CALvo-Goller \& M. Calvo, The SALT Agreements: Content-Application-Verification 261 (1987).

The Interim Agreement permitted the United States to retain its 1054 ICBM launchers and 656 SLBM launchers and allowed the United States to deploy an additional 54 SLBM launchers by retiring a corresponding number of older ICBM launchers. The Soviet Union was authorized to retain its 1618 ICBM launchers and 740 SLBM launchers, which it could increase to 950 with corresponding reductions. See AGDA TREATY Book, supra note 14, at 149. 
viet "heavy" intercontinental ballistic missiles (ICBMs), represented by the SS-9, then the largest and most powerful weapon in the Soviet arsenal. ${ }^{34}$ The United States had and sought no exact counterpart for this weapon, but wanted to control the size of the Soviet deployment. ${ }^{36}$ The Interim Agreement therefore prohibited the construction of additional fixed, land-based launchers for heavy missiles, ${ }^{36}$ and also prohibited the conversion of launchers for light or older ICBMs into launchers for modern heavy ICBMs. ${ }^{37}$

The delegations, however, were unable to agree upon a precise definition of a "heavy" missile. At the conclusion of the negotiations, the United States delegation made a "unilateral statement" 38 that the United States "would consider any ICBM having a volume significantly greater than that of the largest light ICBM now operational on either side to be a heavy ICBM." ${ }^{39}$ The United States delegation added

34 See G. SMith, Doubletalk: The Story of SALT I 388-89 (1985); S. TALBOTT, supra note 29, at 24-27; ACDA TREATY Book, supra note 14, at 148; News Conference Remarks by Presidential Assistant Kissinger, May 29, 1972, 69 ACDA Documents on Disarmament 1972, at 235, 236-37. The SS-9 was designed to replace the second generation Soviet ICBM, the SS-7. The SS-9's greater accuracy, throw-weight and its potential for delivering multiple re-entry vehicles led many in the United States to conclude that it was deployed as a counter-force weapon targeted against the United States Minuteman ICBMs and their launch control centers. See R. Berman \& J. Baker, Soviet Strategic Forces: Requirements and Responses 53 (1982). This led to serious debate whether the Soviets accepted the American doctrine of mutual assured destruction or were interested in creating a destabilizing preemptive strike capability.

3s The United States did have fifty-four Titan II missiles, which were "large" but not "modern," and therefore not covered by this aspect of the Interim Agreement. The Titan, due to primitive inertial guidance systems, was relatively inaccurate, so it carried a large-yield warhead to compensate. It also employed liquid fuel, which increased its unreliability and bulk. One of the reasons the United States never deployed a weapon equivalent to the SS-9 was the American technological superiority in miniaturization and accuracy. When American military doctrine shifted to flexible response and mutual assured destruction ("MAD") under President Kennedy, technology permitted development of the Minuteman missile. Small (one-fifth the size of Titan), accurate, relatively inexpensive and solid-fueled, the Minuteman eliminated the United States' need for a heavy-payload missile with counter-force capabilities. The United States military determined that it was not interested in procuring heavy missiles, preferring to concentrate instead on larger numbers of smaller missiles. See Senate Foreign Relations Committee, Report on the SALT II TReaty, S. EXec. Rep. No. 14, 96th Cong., 1st Sess. 68-69, 167-73 (1979) [hereinafter SFRC SALT II REPORT]; S. TALBOTT, supra note 29 , at 25 .

${ }_{38}$ See Interim Agreement, supra note 13, art. I.

${ }^{37}$ See Interim Agreement, supra note 13, art. II.

38 During the SALT I negotiations, unilateral statements were utilized to state formally for the record one nation's view of a contested matter on which agreement had not been reached. Selected unilateral statements (as well as certain "agreed statements" and "common understandings" which reflected details of areas of consensus) were published alongside the ABM Treaty and the Interim Agreement. See HFAC REPORT, supra note 31, at 5; ACDA TREATY Book, supra note 14, at 135-36, 143-47, 154-57.

3o Interim Agreement, supra note 13, Unilateral Statement D. 
that " $[t]$ he United States proceeds on the premise that the Soviet side will give due account to this consideration." ${ }^{30}$ The USSR delegation, on the other hand, continued to insist that an agreed definition of heavy ICBMs was not essential, and that the Soviet government did not agree with the United States's unilateral statement. ${ }^{41}$

When the Nixon Administration presented the Interim Agreement to the Congress, ${ }^{42}$ the unilateral statement was attached. ${ }^{43}$ Administration spokespersons never exactly said that the USSR had formally accepted the United States definition of heavy missiles, but they nonetheless conveyed to the Congress and to the public the impression that this matter would not prove contentious in implementing the agreement. ${ }^{44}$ For example, then National Security Advisor Henry Kissinger described the American unilateral statement on heavy missiles as a "safeguard."45

Shortly after the Interim Agreement entered into force, however, the Soviet Union began to flight test and deploy the new SS-19 ICBM,, which was a "middle" case, being heavier than the heaviest

$40 I d$.

11 The Soviets declined to define heavy missiles, in order to protect their fourth generation ICBMs then under development, particularly the massive SS-18 and the smaller SS-19. The United States knew these missiles were under development at the time. See G. Duffy, Compliance and the Future of Arms Control 142 (1988); see also Joint Hearings, supra note 1, at 137-38 (statement of Assistant Secretary of Defense Richard N. Perle) (maintaining that the Soviet Union refused to define heavy missiles because their new secret missile was so important to defense modernization); Department of State Bureau of Public Affairs, Compliance with SALT I AGREEMENTS, SPECIAL ReP. 55, at 2 (July 1979) (same); G. SMITH, supra note 34, at 388-91 (same).

42 The Interim Agreement was considered by both Houses of Congress as an executive agreement. The ABM Treaty, on the other hand, was sent only to the Senate for consideration as a treaty. See infra note 54.

43 The use of unilateral statements was criticized heavily after the Soviets failed to honor the United States' position regarding heavy missiles. Observers commented that unilateral statements were insufficient to bind the other party and simply provided a road map of contentious issues that might divide the parties in the future implementation of the accord. See G. SMITH, supra note 34, at 460; S. TALbotT, supra note 29, at 30 . In the SALT II Treaty, the United States did not rely upon any such unilateral statements in the same way. See SFRG SALT II REPORT, supra note 35, at 114-16, 133-35.

44 See, e.g., G. DuFFy, supra note 41, at 142 (maintaining that Henry Kissinger conveyed a misleading impression).

4s See Military Implications of the Treaty on the Limitations of Anti-Ballistic Missile Systems and the Interim Agreement on Limitation of Strategic Offensive Arms: Hearings before the Comm. on Armed Services of the Senate, 92nd Cong., 2d Sess. 128 (1972) [hereinafter Military Implications Hearings] (reprinting Kissinger's statements during White House press conference).

${ }^{4}$ The SS-19 became a special concern to American officials because it was the first large Soviet ICBM to be tested with multiple warheads, greatly expanding its offensive potential. See R. BERMAN \& J. BAKER, supra note 34, at 104-105. 
previous "light" missile (the SS-11,) but lighter than the lightest previous "heavy" missile (the SS-9). ${ }^{47}$ As such, the missile was inconsistent with the position articulated in the United States's unilateral statement, but it was not inconsistent with the textual limitations of the Treaty itself.

The Soviet flight tests generated an extreme reaction from some members of Congress, who complained that they had been misled by the Nixon Administration into thinking that the Soviet Union would not deploy any new missile inconsistent with the United States understanding, or that the United States would be able to respond vigorously and effectively if the Soviets did so. ${ }^{48}$ In keeping with congressional concerns, United States officials raised the issue of the SS-19 with the Soviets in the Standing Consultative Commission ("SCC"), the body established by the ABM Treaty to deal with issues of Treaty implementation and compliance. ${ }^{49}$

Ultimately, however, the United States acknowledged that the SS19 could not be considered a violation of the Interim Agreement because the Soviet Union had never assented to the American definition of a "heavy" missile. Nevertheless, the existence of larger and increasingly capable ICBMs created significant security questions of concern to both sides. ${ }^{50}$ Further SGG consideration of the SS-19 was ultimately de-

67 The United States delegation proposed that the dividing line between heavy and light missiles should be a volume of seventy cubic meters. The delegations did agree that the dimensions of ICBM launchers "[would] not be significantly increased," and that this term barred increases of greater than $10-15 \%$ of the existing dimensions. See Interim Agreement, supra note 13, Agreed Statement C, Common Understanding A; Military Implications Hearings, supra note 45, at 363-64.

48 In retrospect, it appears that the statements of Administration spokespersons, including Secretary of State Kissinger and Secretary of Defense Laird, in presenting the Interim Agreement to the Senate, were factually accurate. The statements described the delegations' inability to proceed beyond the level of a unilateral statement, and never said that the Soviet Union had assented to the United States viewpoint. See Joint Hearings, supra note 1, at 469 (statement of Sen. Hollings); Soviet Compliance with Certain Provisions of the 1972 SALT I Agreements: Hearings before the Subcomm. on Arms Control of the Comm. on Armed Services of the Senate, 94th Cong., 1st Sess. 6, 13, 18-19 (1975) (colloquy between Senator Jackson and Secretary of Defense James R. Schlesinger); Military Implications Hearings, supra note 45, at 128 (reprinting comments by Secretary Kissinger during White House press conference); $i d$. at 547-49 (testimony of Secretary Laird). The overall impression that was created in the minds of many Senators, however, was that some sort of understanding had been reached regarding the size of future missiles.

49 The Standing Consultative Commission is to "consider questions concerning compliance with the obligations assumed and related situations which may be considered ambiguous." ABM Treaty, supra note 7, art. XIII; see also G. DUFFY, supra note 41, at 163-84; N. Galvo-Goller \& M. Calvo, supra note 33, at 299-327.

so Kissinger stated, "I think it is at least open to question whether the United States can hold the Soviet Union responsible for its own statements when the Soviet Union has asserted that it does not accept this interpretation." Joint Hearings, supra 
ferred because the subsequent SALT II negotiations began to address the question, finally writing a Treaty that included agreement upon a specific definition of "heavy" missiles. ${ }^{51}$

This episode highlighted for members of Congress the need to be clear regarding the precise content of international agreements and the constraints imposed upon the United States and other parties. Congressional misunderstanding, due either to Senators' own failure to scrutinize the full meaning of executive representations, or to outright deception by the Executive, creates an extraordinarily unstable basis for making and living under arms control treaties. ${ }^{\mathbf{5 2}}$

\section{G. The ABM Treaty}

The Treaty on the Limitation of Anti-Ballistic Missile Systems ${ }^{\mathbf{B 3}}$ also was signed by President Nixon and General Secretary Brezhnev in 1972 along with the SALT I Interim Agreement. ${ }^{54}$ It established a mutual and strikingly-low level of strategic defense, forestalling, for the most part, what might otherwise have developed into an expensive and destabilizing race in ABM technology. ${ }^{55}$ In the 15 years of its existence,

note 1 , at 469 (statement of Senator Hollings) (reporting history of inability of the United States's unilateral statement to bind the Soviet Union, and attributing statement to Kissinger).

${ }^{61}$ See Treaty on the Limitation of Strategic Offensive Arms, June 18, 1979, United States-USSR (did not enter into force), art. II.7, S. ExEc. Doc. Y, 96th Cong., 1st. Sess. (1979) [hereinafter SALT II Treaty]. Under the provisions of the SALT II Treaty, the SS-19 was considered to be the heaviest of the light ICBMs. See id. at art. II.5 (Third Common Understanding).

${ }^{52}$ See infra notes 118-124 and accompanying text (discussing the fact that the United States is still bound internationally by the agreement as ratified, regardless of how it was represented to the Congress by the Executive).

ss ABM Treaty, supra note 7.

54 The Treaty received the Senate's advice and consent to ratification by a vote of 88-2. See 118 CoNG. REC. 26,770 (1972).

${ }_{5 s}$ The ABM Treaty acknowledges and enhances the strategic concept of mutual assured destruction ("MAD"), wherein each superpower is deterred from attacking the other by fear of overwhelming, unstoppable retaliation. Initially, the Soviet Union was reluctant to embrace this doctrine, arguing as the Reagan Administration later did, that reliance upon defensive systems is preferable to reliance upon offenses and that efforts to reduce the destructiveness of war were preferable to a policy of rendering each nation defenseless. See, e.g., Chayes, The ABM Treaty and the Strategic Defense Initiative, 5 PACE L. REv. 735, 737-38 (1984) (citing Premier Kosygin's exchanges with Defense Secretary McNamara during the Glassboro summit).

Soviet military doctrine appears to have changed dramatically during this period, leading to acceptance of the concept of deterrence. See, e.g., McGuire, Why the Soviets Are Serious About Arms Control, in 36 Proceedings of The Academy of PolitiCAL Science, Soviet Foreign Policy 78, 78-86 (R. Laird ed. 1987) (noting that a variety of factors, such as technological developments and the French withdrawal from NATO, led the Soviets to reassess the risk of automatic escalation to central system strategic exchanges during wartime). 
the ABM Treaty has come to be recognized as one of the most successful and important arms control agreements. ${ }^{\text {66 }}$

Under the ABM Treaty, the parties agreed "not to develop, test, or deploy ABM systems or components which are sea-based, air-based, space-based, or mobile land-based", ${ }^{57}$ and to restrict their deployments of fixed land-based ABM systems (the only permitted type) to just two sites each. ${ }^{58}$ The parties also dealt specifically with the problem of "exotic" or "futuristic" ABM systems and components (such as high-energy lasers), which had yet to be created but which were then projected to be capable of some day substituting for, and performing the function of, ABM interceptor missiles or radars. ${ }^{58}$ The text of the Treaty and an accompanying Agreed Statement ${ }^{60}$ establish a regime for dealing with these ABM systems based on "other physical principles" beyond those of 1972-type technology. ${ }^{61}$

${ }^{5 B}$ See Joint Hearings, supra note 1, at 285 (statement of Senator Biden) (referring to the ABM Treaty as "the most important control agreement in existence"); $A B M$ Treaty Interpretation Dispute: Hearing before the Subcomm. on Arms Control, International Security and Science of the House Comm. on Foreign Affairs, 99th Cong., 1st Sess. 155 (1985) [hereinafter HFAC ABM Hearings] (reprinting a collection of recent statements on the importance of the ABM Treaty by American and allied officials); President's Commission on Strategic Forces Report, April 6, 1983, at 5, 10,12, 16-17 [hereinafter ScowCrofT Commission REPORT] (noting the ABM Treaty's limitation on the development of ballistic missile defenses).

${ }^{57}$ ABM Treaty, supra note 7 , art. V.

${ }^{88}$ See id., art. III. The number of sites permitted to each side was reduced to one by a 1974 protocol. See Protocol to the Treaty on the Limitation of Anti-Ballistic Missile Systems, July 3, 1974, United States-USSR, 27 U.S.T. 1645, 1648 T.I.A.S. No. 8276 [hereinafter Protocol to the ABM Treaty].

${ }^{59}$ See ABM Treaty, supra note 7, Agreed Statement D. The 1972-era ABM systems were based upon interceptor missiles, which would ascend from ground bases, fly near the incoming warhead and explode. Systems based on "other physical principles" would include ground-based installations that might generate energy beams or subatomic particle beams that would deposit lethal energy into the incoming warheads. Neither the United States nor the Soviet Union possessed such weapons in 1972, and neither was close to developing the necessary technology, but systems of this type were contemplated or at least imagined. See Strategic Defense Initiative: Hearings before Subcomm. on Strategic and Theater Nuclear Forces of the Senate Armed Services Comm., 99th Cong., 1st Sess. 193 (1985) [hereinafter 1985 SDI Hearings] (statement of Ambassador Gerard C. Smith, chief SALT I negotiator) ("It was perfectly clear to us that in 1972 the concepts of lasers and particle beam weapons and direct energy weapons were well known."). The SALT I negotiations concerning exotic weapons proved, however, to be difficult and protracted. See Joint Hearings, supra note 1, at 330 (supplementary responses of Raymond L. Garthoff).

60 ABM Treaty, supra note 7, Agreed Statement D.

61 The content of this regime has become controversial. Most experts believe that the ABM Treaty included a ban on the development, testing, and deployment of mobile ABM systems that embody either 1972-type or other technology. The Reagan Administration, however, concluded that the Treaty may be read to permit development and testing, but not deployment, of mobile ABM systems based on "other physical principles." See infra notes 71-89 and accompanying text. 
For the first decade after its entry into force, the ABM Treaty attracted relatively little attention. ${ }^{\mathbf{6}}$ That changed, however, on March 23, 1983, when President Reagan delivered his famous "Star Wars" speech, ${ }^{63}$ inaugurating the Strategic Defense Initiative ("SDI"), ${ }^{64}$ and seeking to establish for the United States a defensive capability for rendering incoming ballistic missile warheads "impotent and obsolete." The President declared that the SDI would initially be only a research program, to be conducted in compliance with the ABM Treaty. ${ }^{66}$ If the SDI research proved fruitful, it was suggested, the ABM Treaty ulti-

62 The major compliance-related issue concerning the ABM Treaty has been the Soviet construction of a large phased-array radar installation at Abalakova near the city of Krasnoyarsk in Siberia. The United States has made a formal charge that the radar violates the ABM treaty. See Taubman, Moscow Proposes to Remove Radar Criticized by U.S., N.Y. Times, July 20, 1988, at A1, col. 3; Gordon, Split Is Reported Over ABM Accord, N.Y. Times, July 15, 1988, at A5, col. 1. Other, more minor implementation issues have surfaced over the years, but have not proved highly contentious. See, e.g., T. Longstreth, J. Pike \& J. Rhinelander, The IMPaCt of U.S. and Soviet Balisistic Missile Defense Programs on the aBM Treaty, National Campaign to Save THE ABM Treaty 33-37 (1985) (describing the "gray area" programs such as anti-satellite systems and anti-tactical ballistic missile systems that both the United States and Soviet Union maintain fall outside the narrow interpretation of the ABM Treaty); A. SchorR, Legal Issues of THE "STAR WARs" Defense Program 9-17 (1984); Chayes, supra note 55, at 740-46; Haass, The ABM Treaty: Verification and Compliance Issues, in The ABM Treaty: To Defend OR Not To Defend? 121 (W. Stützle, B. Jasani \& R. Cowen eds. 1987).

63 National Security: President Reagan's address to the Nation, 19 WeEkLY COMP. PREs. Doc. 442 (Mar. 23, 1983) [hereinafter Presidential address].

of The United States had long maintained a relatively modest research program in the area of ballistic missile defense, spending roughly $\$ 1$ billion per year, primarily as a hedge against a Soviet "breakout" of the ABM Treaty through new technology. The SDI program, however, was to be vastly more ambitious and to receive a much higher level of funding. See T. Longstreth, J. Pike \& J. Rhinelander, supra note 62, at 11-18. The Pentagon drew up plans for spending $\$ 70$ billion on SDI between 1984 and 1993 , and $\$ 14$ billion has already been appropriated. See Star Wars Reality, 17 DefENSE MONITOR 1,1 (1988).

${ }^{65}$ Presidential address, supra note 63, at 448. Many of the President's advisors had, and still maintain, more modest goals for SDI. For example, developing a lessthan-perfect defensive system would complicate Soviet offensive planning and force the Soviets to undertake higher offsetting expenditures. See 1985 SDI Hearings, supra note 59, at 17-18 (testimony of Lt. Gen. James A. Abrahamson, Director of the Strategic Defense Initiative Organization, and Fred C. Ikle, Under Secretary of Defense for Policy); United States Department of Defense, Strategic Defense InItiative Organization, Report to the Congress on the Strategic Defense IniTIATIVE III, at 5-8 (June 1986); see also Address by Paul H. Nitze before the North Atlantic Assembly in San Francisco, SDI: Its Nature and Rationale (Oct. 15, 1985), reprinted in 85/2105 DEP'T ST. BULL. 69 (1985) (describing SDI as a cost-effective defense that could so complicate first strike calculations as to make them virtually impossible).

${ }^{66}$ See United States Department of Defense, Strategic Defense Initiative ORGanization, supra note 65 , at 7 ("It should be stressed that the SDI is a research program that seeks to provide the technical knowledge required to support a decision on whether to develop and later deploy advanced defensive systems. . . . All research efforts will be fully compliant with United States treaty obligations."). 
mately would have to be renegotiated and amended. ${ }^{67}$ Critics, however, concluded that the Soviet Union would never agree to such a substantial amendment - an amendment that would, in effect, gut the treaty's central purposes. They argued that in order to pursue SDI, the United States would ultimately have to withdraw from the ABM Treaty, or abrogate it. $^{68}$

As SDI research progressed, the constraints of the ABM Treaty loomed as a larger and more immediate hurdle to advanced development and testing of esoteric anti-missile system components. ${ }^{69}$ Accord-

67 See Smith, "Star Wars" Tests and the ABM Treaty, 229 ScIEnCE 29, 29 (1985) (citing statement of AGDA Director Kenneth Adelman). President Reagan also proposed sharing SDI technology with the Soviet Union, a proposal which generated a great deal of controversy. See 1985 SDI Hearings, supra note 59, at 18-19, 94; Transcript of Group Interview with President at White House, N.Y. Times, Mar. 30, 1983, at A14, col. 2.

${ }^{8 B}$ See 1985 SDI Hearings, supra note 59, at 192 (statement of Ambassador Smith). As the Ambassador stated:

Some officials speak of amending the [ABM] treaty [to permit SDI]. To my mind that would be tantamount to having tried to amend the Volstead Act to permit the sale of liquor. The recent reinterpretation of the treaty is, I suppose, an effort to amend the treaty unilaterally as it becomes clear that the Soviets have no interest in liberalizing existing constraints. They seem to favor tightening the treaty.

Id.; see also Implications of the President's Strategic Defense Initiative and Antisatellite Weapons Policy: Hearings before the Subcomm. on Arms Control, International Security and Science of the House Comm. on Foreign Affairs, 99th Cong,, 1st Sess. 50 (1985) [hereinafter HCFA SDI Hearings] (statement of John Rhinelander) ("I cannot conceive of the Soviets agreeing to amend" the ABM Treaty to permit SDI); Chayes, supra note 55, at 746 ("it is hard to hold out much hope for" renegotiation of the ABM Treaty).

Some experts even argued that the Reagan Administration's announcement of SDI and the preparations undertaken for ultimate termination of the ABM Treaty could constitute an "anticipatory breach" of the Treaty, with immediate legal implications. See, e.g., Smith, supra note 67, at 30 (citing statements of Ambassador Gerard Smith and SALT I legal advisor John Rhinelander); Comment, The Role of Arms Control in Strategic Nuclear Doctrine: SDI, MAD, and the ABM Treaty, 62 WASH. L. REV. 763, 764 (1987) (stating that the United States must choose between SDI and the ABM Treaty).

${ }_{68}$ There has been some controversy concerning the time period within which the planned SDI tests could be conducted in accord with the original, restrictive interpretation of the ABM Treaty. Some officials (including Lt. Gen. Abrahamson, Director of the SDI Organization of the Department of Defense) have suggested that the conflict between the original interpretation and the planned testing program will not occur until some years into the future; others (including then-Assistant Secretary of Defense Richard Perle) have contended that the constraints of the original interpretation of the ABM Treaty already may be impinging upon progress in SDI. See 133 ConG. REC. S2974 (daily ed. Mar. 11, 1987) (statement of Senator Nunn); see also 1985 SDI Hearings, supra note 59, at 399 (testimony of Lt. Gen. Abrahamson) (stating that development can proceed under the restrictive interpretation into the early 1990s); HCFA SDI Hearings, supra note 68, at 70 (joint statement of John Pike and Thomas K. Longstreth) (arguing that SDI development will be inconsistent with the ABM Treaty); G. DufFY, supra note 41, at 115 ("The prohibitions on development con- 
ingly, the Department of Defense, the Department of State Legal Adviser, and ultimately in October 1985, the Reagan Administration as a whole, propounded a "new interpretation" of the ABM Treaty - an interpretation that was substantially more permissive regarding SDI development and testing. ${ }^{\text {70 }}$

Under the new interpretation, the Treaty's basic ban on the development and testing of space-based and other mobile ABM systems and components would apply only to "current" (that is, 1972-type) technology. Space-based and other mobile "exotic" systems, based on "future" (post 1972) ABM technology would be governed only by the provisions applicable to fixed, land-based exotics. The net effect of the new interpretation was that development and testing would be permitted, and only deployment would be prohibited. ${ }^{71}$

Reaction to the new interpretation was profound and widespread, and dealt with two related but distinct issues: the factual merits of the new interpretation, and the constitutional authority for asserting it. ${ }^{\mathbf{2}}$

\section{Substance of the Reinterpretation Issue}

Most of the senior members of the United States SALT I negotiat-

tained in the ABM Treaty would start at the part of the development process where field testing is initiated on either a prototype or breadboard model."); T. LONGSTRETH, J. Pike \& J. Rhinelander, supra note 62, at 51 (providing a chart of scheduled SDI tests that would raise compliance issues).

70 Several offices in different parts of the government played a role in shaping the new interpretation in late 1984 and 1985. See Joint Hearings, supra note 1, at 203-05 (statement of William Sims, former attorney advisor, Department of State); 1987 SFRC REPORT, supra note 4, at 24-27; 133 CONG. REC. S2974 (daily ed. Mar. 11, 1987) (statement of Sen. Nunn); see also R. Garthoff, Policy Versus The Law: The Reinterpretation of THE ABM Treaty 2-9 (1987) (recounting history of evolution of new interpretation).

${ }_{71}$ The critical step for the new interpretation is to convert the definition of ABM systems, contained in Article II of the Treaty, from a "functional" definition (in which all equipment that could operate as an anti-ballistic missile system or component would be covered by the Treaty) into a "limiting" definition (in which the Treaty applies only to those types of ABM systems and components that are specifically mentioned in Article II). Sofaer concedes that the original reading is "plausible," but asserts that it has "serious shortcomings." See Sofaer, The ABM Treaty and the Strategic Defense Initiative, 99 HaRv. L. REv. 1972, 1974 (1986).

${ }_{72}$ Some argued that the "fundamental question" was solely whether SDI was in the national security interest of the United States, and that the question of the legal propriety of the reinterpretation of the ABM Treaty was like arguing "about how many angels dance on the head of a pin." Joint Hearings, supra note 1, at 17 (statement of Sen. Evans). Others responded that even if the United States did seek to pursue SDI and to abandon the limitations of the ABM Treaty, it would be better to do so "frontally, not by skirting the issue" with a reinterpretation. Id. at 17 (statement of General Allison). See generally Office of Technology Assessment, Ballistic Missile Defense Technologies, OTA-ISC-254 (1985) (assessing technical and political merit of SDI). 
ing delegation denounced the new interpretation as a misreading of the ABM Treaty's text and negotiations, which they said had produced a more comprehensive ban on ABM systems. ${ }^{73}$ Several leading Senators, with recent access to the classified negotiating record, also criticized the new interpretation as an attempt to rewrite history. ${ }^{74}$ Academic experts scrutinized the process of Senate advice and consent, as well as the subsequent record of $A B M$ Treaty implementation, finding scant evidence to support the "broad" interpretation. ${ }^{\text {" }}$ The Soviet Union also denied the historical accuracy of the new interpretation, and condemned it as an attempt to subvert the ABM Treaty. ${ }^{78}$

${ }^{73}$ See Joint Hearings, supra note 1, at 6 (statement of Lt. Gen. Royal B. Allison (USAF-Ret.), member of the United States ABM Treaty negotiating delegation) (noting that both United States and Soviet sides understood that the ABM Treaty prohibited development and testing of mobile exotic systems); id. at 7-8 (statement of Raymond L. Garthoff, Executive Secretary and senior advisor to the United States ABM Treaty negotiating delegation) (asserting that statements made during the negotiating process unambiguously support the traditional, restrictive interpretation); $i d$. at 495-96 (joint letter from negotiators of the ABM Treaty supporting the traditional restrictive interpretation as the correct one). Former President Richard Nixon, under whom the $A B M$ Treaty was negotiated, also has endorsed the original interpretation of the Treaty, saying that it was this view of the Treaty which his administration presented to the Senate in 1972. See Bunn, Nixon Supports Nunn on ABM Treaty, ARMS CoNTROL TODAY, May 1988, at 21. But see Nitze, supra note 65, at 71 (arguing that SDI is consistent with the ABM Treaty and noting that the Soviet position on the scope of the Treaty has been inconsistent); Address by Paul H. Nitze, Interpreting the ABM Treaty (Apr. 1, 1987), reprinted in Joint Hearings, supra note 1, at 493 (same). Nitze, the only former ABM Treaty negotiator to hold a position in the Reagan Administration, is also the only one to endorse the broad interpretation of the ABM Treaty.

74 Senator Nunn has stated repeatedly that the new interpretation is historically inaccurate. See 133 Cong. REc. S6809-31 (daily ed. May 20, 1987); 133 Cong. Rec. S3090-95 (daily ed. Mar. 12, 1987); 133 ConG. Rec. S3171-73 (daily ed. Mar. 13, 1987); 133 Cong. REC. S2973-82 (daily ed. Mar. 11, 1987); see also Smith, Reinterpretation of ABM Treaty Hit, Wash. Post, Dec. 2, 1986, at A8, col. 1 (reporting a letter to Secretary of State Schultz from Senator Levin condemning the reinterpretation as fatally flawed).

75 See, e.g., Committee on InT'L ARMS ConTrol and Security AfFaIRS, Ass'N of the Bar of the Gity of New York, The Anti-Ballistic Missile TREATY INTERPRETATION DISPUTE 6-7 (1988) (stating that the negotiating history, ratification debates and subsequent practice all support the traditional interpretation); Chayes \& Chayes, supra note 5, at 1957-69 (arguing that neither the Treaty text, negotiating record, nor subsequent practice support the Reagan Administration's reinterpretation); Gross, Negotiated Treaty Amendment: The Solution to the SDI-ABM Treaty Conflict, 28 HARv. INT'L L.J. 31, 34-38, 46-52 (1987) (arguing that the reinterpretation is legally deficient and an undesirable way out of the ABM/SDI conflict); Klema, supra note 5, at 156-65 (applying the principles of treaty interpretation established by the Vienna Convention to the ABM Treaty).

${ }^{76}$ See, e.g., Joint Hearings, supra note 1, at 58 (statement of Sen. Nunn) (quoting statement of then Soviet Chief of General Staff Marshall Akhromeyev, in support of the traditional interpretation of the ABM Treaty); id. at 410-11 (1983 interview with Soviet official regarding SDI and the ABM Treaty); R. GARTHOFF, supra note 70 , at $85-88$ (noting the numerous Soviet statements since October 1985 that reaffirm 
The Reagan Administration, nonetheless, continued to assert that the new interpretation was legally correct and supported by the ABM Treaty record. ${ }^{77}$ The State Department Legal Adviser identified what he considered to be numerous "ambiguities" - in the Treaty's text, the negotiating record, the Senate's legislative history, and the parties' subsequent practice - which, he asserted, cast doubt upon the 1972 understandings of the Treaty's accomplishments. ${ }^{78}$ However, the Administration conceded that at least for the interim, it would comply - as a policy, rather than as a legal matter - with the constraints of the "original" interpretation. ${ }^{79}$

the traditional interpretation and reject the Reagan Administration position); Vereshchetin, Issues Related to Current U.S. and Soviet Views of the Treaty: A Soviet Jurist's Perspective, in The ABM Treaty: To Defend or Not to Defend?, supra note 62, at 105; Voas, $A B M$ Treaty Interpretation: The Soviet View, in CoNgressional Research Service, Office of Senior Specialists, Report 85-1020, at 5 (Oct. 25, 1985). But see Joint Hearings, supra note 1, at 38-39 (statement of Senator Wilson) (Soviets originally favored broad interpretation, but changed to the narrow interpretation when they realized that the United States could embark on a technological advance in ABM systems to their detriment); Kassel, Soviet Research and Development of Directed-Energy Weapons, in THE ABM TREATY: To DEFEND OR Not To DEFEND?, supra note 62, at 75 (discussing Soviet research concerning SDI equivalents); Sofaer, supra note 71, at 1985 n.37 (Soviets made few statements about scope of ABM Treaty until United States announced SDI, and even thereafter, Soviets did not promptly and consistently claim that SDI was a violation of the Treaty).

Other states, including important United States allies, were hesitant about the new interpretation, or opposed to it. See R. GARTHOFF, supra note 70, at 3, 16; see also NATO Defense and the INF Treaty: Hearings before the Senate Comm. on Armed Services, 100th Cong., 2d Sess. 309 (1988) [hereinafter NATO Defense Hearings] (comments of Senator Levin). Some have since supported it. See 1985 SDI Hearings, supra note 59, at 366 (statement of Assistant Secretary of Defense Richard Perle) (surveying allies' and other states' attitudes toward participation in SDI research); $c f$. United States Department of Defense, Strategic Defense Initiative ORGANIZATION, supra note 65, Appendix B (describing consultations with allies).

${ }_{77}$ See Joint Hearings, supra note 1, at 119 (statement of Assistant Secretary of Defense Richard N. Perle); HFAC ABM Hearings, supra note 56, at 200-212 (Analysis of United States and Soviet Analysis of United States and Soviet Post-negotiation Public Statements Interpreting the ABM Treaty's Application to Future Systems, submitted by Judge Sofaer in response to a question posed during the Hearing); Sofaer, The ABM Treaty, reprinted in 133 Cong. REc. S6,623-63 (daily ed. May 19, 1987) (Part I: Treaty Language and Negotiating History), 133 CoNG. REC. S6,663-91 (daily ed. May 19, 1987) (Part II: Ratification Process) and 133 GoNG. REC. S12,181-84 (Part III: Subsequent Practice) [hereinafter Sofaer, ABMT Reports]. The Department of Defense began referring to the "broad interpretation" simply as the "legally correct interpretation," abbreviated to "LCI," see Joint Hearings, supra note 1, at 172 (statement of Professor Abram Chayes); id. at 470 (statement of Richard Perle), and informed the Soviet delegation in Geneva of this view. See Morrison, ABM Tightrope, 19 NAT'L J. 1752, 1752 (1987).

${ }^{78}$ See Joint Hearings, supra note 1, at 31 (statement of Senator Wilson) (United States negotiators in 1972 attempted to obtain Soviet agreement to ban future types of ABM systems, but the Soviet delegation consistently declined); see also Sofaer, supra note 71 , at 1972 .

${ }^{78}$ See, e.g. Joint Hearings, supra note 1, at 475 (statement of Richard N. Perle, 
More recently, Congress declared its support of the original interpretation, by mandating in the Fiscal Year 1988-89 National Defense Authorization Act that no funds could be used for SDI tests other than those previously announced - tests that Congress and the Executive already had determined would not contravene the original interpretation of the Treaty. ${ }^{80}$

\section{Process of the Reinterpretation Issue}

At the same time that the factual or substantive accuracy of the new interpretation was scrutinized, its legitimacy under the Constitution also came under fire, with many critics challenging the Executive's authority to implement any such alteration in the established meaning of a treaty. ${ }^{\mathbf{8 1}}$

The first return salvo from the Reagan Administration came in March 1987, when Abraham Sofaer, Legal Adviser of the Department of State, testified to a joint hearing of the Senate Foreign Relations and Judiciary Committees that: "When [the Senate] gives its advice and consent to a treaty, it is to the treaty that was made, irrespective of the explanations [the Senate] is provided."

Assistant Secretary of Defense) (affirming that the President decided that SDI program need not be structured to approach the boundaries of the broad interpretation, but reserving the right to restructure the program in the future); 1985 SDI Hearings, supra note 59, at 141-42 (testimony of Abraham D. Sofaer, State Department Legal Adviser) ("[N]otwithstanding our belief in the merits of the broader interpretation, the President has decided to pursue the SDI Program as currently structured, which can be accommodated within the confines of the restrictive interpretation ...."); HFAC ABM Hearing, supra note 56, at 38 (comments of Ambassador Paul Nitze) (stating there is no evidence that either the United States or the Soviet Union has violated the restrictive definition of the ABM Treaty); UntTed States Department of Defense, STRategic Defense Initiative Organizations, supra note 65, Appendix D (describing "the existing process for ensuring compliance with . . . the ABM Treaty").

${ }_{80}$ See National Defense Authorization Act for Fiscal Years 1988 and 1989, Pub. L. No. $100-180, \S 225,101$ Stat. 1019, 1056 (1987). As a compromise between the Congress and the White House, this legislation does not explicitly state that the SDI program is to be confined to activities that are consistent with the original interpretation of the ABM Treaty. Instead, it accomplishes the same objective by referring to an earlier published description of planned SDI tests, which all participants agreed were, in fact, consistent with the narrow interpretation. The Conference Committee report then confined the Department of Defense SDI activities to that list. See H.R. REP. No. 446, 100th Cong., 1st Sess. 594 (1987).

${ }^{81}$ See Glennon, Interpreting "Interpretation": The President, the Senate, and When Treaty Interpretation Becomes Treaty Making, 20 U.C. Davis L. REv. 913, 919 (1987) (concluding that when the President exceeds the bounds of good faith construction, "his endeavor represents not construction or interpretation at all, but the making of a new treaty").

${ }_{82}$ Joint Hearings, supra note 1 , at 130 . An incredulous Senator Biden, chairing the hearing, asked the Legal Advisor to repeat his statement, and called it "absolutely staggering." Id. 
In May of 1987, the Legal Adviser elaborated this view, concluding in a detailed study that a President is free to depart from a previously-held treaty interpretation unless three conditions had been met. Under the Sofaer Doctrine, ${ }^{83}$ the Executive's representation to the Senate can be relied upon only if it had been "generally understood," "clearly intended," and "relied upon" by the Senate during the treaty ratification process. ${ }^{84}$ The Doctrine was then advanced as a foundational justification for the new interpretation of the ABM Treaty, since the original interpretation allegedly failed all three of these standards with respect to the 1972 ratification process. ${ }^{85}$

The Senate, however, reacted vigorously in opposition to the Sofaer Doctrine. ${ }^{86}$ In March and April of 1987, the Senate Foreign

8s The Sofaer Doctrine has never been articulated with clarity as a principle of constitutional law; it has arisen from the combination of Sofaer's testimony, see supra notes 77-78 and accompanying text, the memorandum from the Office of Legal Counsel, see Memorandum from Charles J. Cooper, Assistant Attorney General, Office of Legal Counsel, to Abraham D. Sofaer, Legal Adviser, Department of State, Relevance of Senate Ratification History to Treaty Interpretation, (Apr. 9, 1987) [hereinafter OLC Memorandum] (on file with the University of Pennsylvania Law Review), and subsequent letters from White House Counsel Arthur Culvahouse. See Letters from White House Counsel Arthur B. Culvahouse to Senator Richard D. Lugar, (Mar. 17 \& 22,1988$)$, reprinted in INFT REPORT, supra note 8 , at 443, 446; see also Biden \& Ritch, The End of the Sofaer Doctrine: A Victory for Arms Control and the Constitution, Arms ConTrol Today, Sept. 1988, at 3, 5.

The Legal Advisor has stated that his March 1987 testimony regarding the nonbinding effect of Executive Branch statements, had been intended to be confined to the observation that United States statements made during the ratification process were not binding internationally, and had no effect upon the Soviet Union. See Sofaer, Letter to the Editor, Time, Apr. 27, 1987, at 10. The Legal Advisor also has written that "[t]he President should give appropriate weight to Executive representations made to Congress, and expectations developed by legislators, during the post-ratification period, in determining and exercising his lawful discretion to interpret the ABM Treaty." Sofaer, $A B M T$ Reports, supra note 77 , at $\mathrm{S} 12,184$.

s4 See Chronology of Executive/Senate Action on Treaty Interpretation, in INFT REPORT, supra note 8, at 447; Sofaer, ABMT Reports, supra note 77, at S12,184 (stating that the "President's powers to interpret treaties and to conduct foreign affairs should not be limited absent clear indication that such limitations were specifically intended").

In preparing his report, the Legal Advisor relied substantially upon a study conducted by the Office of Legal Counsel of the Department of Justice, discussing the respective roles of executive branch testimony and of Senators' statements in the legislative history of a treaty. See generally OLG Memorandum, supra note 83.

88 See Sofaer, ABMT Reports, supra note 77, at S6,664.

${ }^{86}$ See, e.g., Smith, Reinterpretation of $A B M$ Treaty Hit, Wash. Post, Dec. 2, 1986, at A8, col. 1 (discussing Senator Levin's criticism of the Sofaer Doctrine). Some in the Senate not only supported the Sofaer Doctrine, however, but articulated an even stronger version of it. See Joint Hearings, supra note 1, at 100-101 (statement of Senator Biden, quoting a letter from Senator Dole to the President) ("The views of the Senate on interpretation of a treaty are legally irrelevant and in no way bind the President unless those views are expressed (1) formally and (2) at the time of the Senate's decisions of advice and consent."). 
Relations Committee and Judiciary Committee held joint hearings on the ABM Treaty and the Constitution, ${ }^{87}$ and the Foreign Relations Committee later favorably reported the Biden Resolution, ${ }^{88}$ affirming that the President is constitutionally bound to adhere to all authoritative interpretations offered during the ratification process until the Senate agrees to a change. ${ }^{89}$

\section{The INF Treaty}

The logical culmination of the ABM Treaty reinterpretation controversy occurred during the spring of 1988 , in the context of the ratification of the Treaty on the Elimination of Intermediate-Range and Shorter-Range Missiles. ${ }^{90}$ The INF Treaty provides for elimination of the parties' stockpiles of ground-based missiles capable of reaching distances between approximately 300 and 3500 miles. $^{91}$

The INF Treaty attracted widespread, bipartisan support and on May 27, 1988, the Senate gave its consent ${ }^{82}$ to the Treaty by a vote of ninety-three to five. ${ }^{93}$ One salient issue that surfaced during the Senate debate, becoming a major perturbation in the ratification process, again concerned the constitutional implications of the "reinterpretation" question. ${ }^{94}$ A number of prominent Senate Democrats, led by Senators

${ }^{87}$ See Joint Hearings, supra note 1.

${ }^{88}$ See S. Res. 167, 100th Cong., 1st Sess. (introduced Mar. 12, 1987), reprinted in 1987 SFRC REPORT, supra note 4, at 117-20; id. at 37 (noting the committee's vote to recommend favorably the resolution on May 19, 1987). The resolution was never brought for consideration by the Senate as a whole, as the Congress worked instead on the limitations on SDI funding. See Biden \& Rich, supra note 83, at $8 \mathrm{n.3}$; supra note 80 and accompanying text.

89 The key provisions of the Biden Resolution stated that the meaning of a treaty is "what the Senate understands the treaty to mean when it gives its advice and consent," that the understanding of the Senate may be manifested by Senate approval and acceptance or acquiescence in interpretations of the treaty communicated to the Senate by the Executive Branch, and that the contents of the secret negotiating record, not brought to the attention of the Senate, cannot be a part of the Senate's understanding of the treaty. See S. Res. 167, supra note $88, \S 2(2)(B)-(D)$.

90 INF Treaty, supra note 8.

81 The INF Treaty will require the Soviet Union to dismantle 1836 missiles and the United States to dismantle 859. It will result in the removal of 2200 nuclear warheads from the superpowers' inventories of deployed missiles. See INFT REPORT, supra note 8 , at 2-3, 56-61.

${ }^{82}$ Partly in response to Senate prodding, United States and Soviet negotiators had continued to work on the INF Treaty during the period between signature and ratification, to resolve a series of ten verification-related questions, the details of which had threatened to delay implementation of the agreement. See Gordon, U.S. and Soviets Say Missile Pact Issue Has Been Resolved, N.Y. Times, May 13, 1988, A1, at col. 6; Dewar, Senate Nears Debate on INF Treaty, Wash. Post, May 14, 1988, A1, at col. 5.

${ }^{93}$ See 134 Cong. Rec. S6937 (daily ed. May 27, 1988).

94 See, e.g., Bedard, Senate Prohibits Reinterpretations, Nears Treaty OK, Wash. Post, May 27, 1988, at A6, col. 5 (reinterpretation controversy is the "last major hurdle 
Byrd, Nunn, Pell, and Biden, sought reassurances from the Reagan Administration that the INF Treaty would not be vulnerable to the same type of reinterpretation that troubled the ABM Treaty. ${ }^{95}$

Secretary of State Shultz initially replied with a letter confirming that the testimony offered by responsible Executive Branch officials could be considered "authoritative"; that the Resolution of Ratification need not explicitly incorporate the executive testimony; and that the Reagan Administration would not depart from the INF Treaty interpretations it had provided to the Senate. The Secretary declined, however, to describe the current testimony and interpretations as being "binding" on future Presidents. ${ }^{98}$

Dissatisfied with the scope of the Secretary's response, the Foreign Relations Committee began to refine the "Biden Condition"97 (later modified and sometimes referred to as the "Byrd Amendment"), ${ }^{98}$ to express in the resolution of ratification the Senate's conviction that competent Executive Branch testimony prior to ratification cannot be

facing the historic INF treaty"); The Treaty and Its Enemies, N.Y. Times, May 25, 1988 , at A26, col. 1 (predicting that ratification would be unlikely unless the Administration reassured the Senate as to the integrity of its role in treaty-making).

${ }^{95}$ See Chronology of Executive/Senate Action on Treaty Interpretation, supra note 84, at 447; Smith, Rift Widens as Biden and Pell Up the Ante, Wash. Post, Feb. 9, 1988, at A20, col. 1; Gordon, White House Criticizes Democrats for Threatening Arms Pact Delay, N.Y. Times, Feb. 7, 1988, at A1, col. 4; Letter from Senators Byrd and Nunn to George Schultz, Secretary of State (Feb. 5, 1988), reprinted in INFT REPORT, supra note 8 , at 447 .

${ }^{96}$ See Letter from Secretary of State George Shultz to Senator Nunn (Feb. 9, 1988), reprinted in INFT REPORT, supra note 8 , at 442 . Some Senators were initially hopeful that the Shultz letter would defuse the controversy; upon further analysis, however, the letter was determined to be consistent with the Sofaer Doctrine, as confirmed by subsequent correspondence. See id. at 94; see also Gordon, 2 Senate Democrats End Threat to Delay Pact, N.Y. Times, Feb. 11, 1988, at A13, col. 1; Smith, Shultz INF Letter Soothes 2 Senators, Angers 3rd, Wash. Post, Feb. 11, 1988, at A21, col. 1.

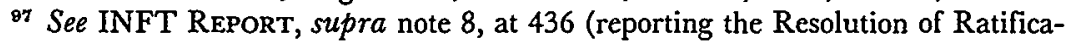
tion containing the "Biden Condition."). The Biden Condition, introduced on behalf of Senator Biden by Senator Cranston, was drafted in consultation with Professor Louis Henkin, chief reporter for the American Law Institute's new Restatement of Foreign Relations Law. See Restatement, supra note 2; INFT REPORT, supra note 8, at 96.

The Biden Condition provided that the United States shall interpret the INF Treaty in accordance with the understanding shared by the Executive and the Senate at the time of Senate consent to ratification, that the common understanding is based upon the text and the authoritative representations provided to the Senate by the Executive, and that the United States shall not adopt a different interpretation except pursuant to a treaty amendment or statute. See id. at 97 . The terms of the Biden Condition were not to be conveyed officially to the Soviet Union See id. at 99-100.

${ }^{88}$ Senator Byrd drafted alterations in the Biden Condition late in the advice and consent period; the changes were relatively insubstantial, designed mostly as a parliamentary tactic to protect against additional, hostile amendments. See Biden \& Ritch, supra note 83, at 7. Compare INFT REPORT, supra note 8, at 436 (Biden Condition) with 134 Cong. Rec. S6937 (daily ed. May 27, 1988) (Byrd Amendment). 
disregarded for a subsequent unilateral reinterpretation. ${ }^{99}$

In March 1988, White House Counsel Arthur Culvahouse sent two letters to Senator Lugar, again asserting the Reagan Administration's position that even "authoritative" Executive Branch testimony is not "binding," unless it satisfies the Sofaer Doctrine's tests of being "generally understood," "clearly intended," and "relied upon" by the Senate during the ratification process. ${ }^{100}$

Many in the Senate felt that the Sofaer Doctrine presented unpalatable choices: if authoritative administration testimony was not automatically binding, then, in order to guarantee that any particular point of interpretation would be reliable in the future, the Senate might have to recite its understanding with a condition or other explicit declaration in the resolution of ratification. There might be a great many points where the Senate would want to insist upon entrenching a durable interpretation. Accordingly, dozens or even hundreds of such conditions might be needed to expressly affix to the resolution of ratification virtually everything that executive branch officials had asserted to the Congress. ${ }^{101}$

Moreover, under these circumstances, the Senate might additionally feel obligated to scrutinize the entire classified negotiating record itself, to ensure that the Executive Branch testimony fairly and accurately represented the true nature of the United States-Soviet understandings. This would require elaborate inspection of voluminous, disparate negotiating documents, a laborious and time-consuming function that the Senate would not be well-equipped to perform. ${ }^{\mathbf{1 0 2}}$

99 The Biden Condition was designed "to reaffirm the long-standing practice and long-standing principle that the 'shared understanding' of the Executive and the Senate, as reflected in the Executive's formal representations, is indeed fully binding." INFT REPORT, supra note 8 , at 96 .

100 See Letters from White House Counsel Arthur B. Culvahouse to Senator Richard D. Lugar (Mar. 17 \& 22, 1988), reprinted in INFT REPORT, supra note 8, at 443, 446; see also 134 Cong. Rec. S6774 (daily ed. May 26, 1988) (statement of Senator Nunn) (recapitulating events leading up to the drafting of the Biden Condition); Gordon, Democrats Clash With Reagan Over Arms Treaty, N.Y. Times, Mar. 20, 1988, at A3, col. 1 (noting Culvahouse's sharp rejection of Senate's position on treaty interpretation).

${ }_{101}$ See Joint Hearings, supra note 1 , at 62 (statement of Senator Nunn). As the Senator stated: "Treaties so laden would sink under their own weight. It would be extremely difficult to achieve bilateral agreements and virtually impossible for the United States to participate in multilateral treaties." Id.; see also INFT REPORT, supra note 8, at 105-06 (stating that the Biden Condition allows the Senate to rely upon administration testimony without the cumbersome process of restating all of it).

102 See Joint Hearings, supra note 1, at 62 (statement of Senator Nunn) (under the Sofaer Doctrine, the Senate would feel compelled to request a complete record of the negotiating history of a treaty in order to ensure that no secret understanding would emerge later); cf. Specter, The Threat to the INF Treaty, N.Y. Rev., Feb. 4, 1988, at 22 (arguing that the Senate should refuse to consider the secret negotiating record in 
Throughout the controversy concerning the reinterpretation conditions that the Senate might attach to the INF Treaty, all participants were fully conscious that more than one treaty was at stake. ${ }^{103} \mathrm{Al}-$ though the Biden Condition did not purport to have any retroactive effect, (or, for that matter, to reach any future agreements besides the INF Treaty), ${ }^{104}$ the controversy surrounding the ABM Treaty was also clearly implicated. As a result, the difference between "authoritative" and "binding" testimony became a surrogate for concerns about the ABM Treaty, the Strategic Defense Initiative, and the constitutional balance of power between the Congress and the President.

Ultimately, on May 26, 1988, the Senate adopted the Biden Condition to the INF Treaty Resolution of Ratification by a vote of seventy-two to twenty-seven. ${ }^{105}$ The resolution stated that "the United States shall interpret the Treaty in accordance with the common understanding of the Treaty shared by the President and the Senate at the time the Senate gave its advice and consent to ratification"; that the common legislative-executive understanding of the Treaty was based in part on the "authoritative representations which were provided by the President and his representatives to the Senate and its Committees"; and that "the United States shall not agree to or adopt an interpretation different from that common understanding except pursuant to Senate advice and consent to a subsequent treaty or protocol, or the enactment of a statute."106

President Reagan exchanged instruments of ratification of the INF Treaty with Soviet General Secretary Gorbachev in Moscow, on June

evaluating the INF Treaty).

In the end, the Foreign Relations Committee, having access to the entire INF Treaty negotiating record, decided to make no findings concerning the content of the record, or concerning the accuracy of Executive Branch representations of it. The Committee determined that it should avoid "institutionalizing" the procedure of detailed Senate scrutiny of the record. In making the point that the Senate was relying directly upon the Executive Branch's presentations regarding the content of the INF Treaty, the Senate indicated that it deliberately would refrain from officially double checking the consistency between the negotiating record and the President's portrayal of it. See INFT REPORT, supra note 8, at 100-01.

In presenting the new interpretation of the $A B M$ Treaty, the State Department had declassified selected portions of the negotiating record and had made the entire record (or the portions of it that could be collected) available to the Senate. See generally Sofaer, $A B M T$ Reports, supra note 77.

${ }^{103}$ See Biden \& Ritch, supra note 83, at 8; Smith, supra note 5, at A17, col.1; Smith, Dispute Threatens INF Treaty, Wash. Post, Feb. 6, 1988 at A1, col. 6.

104 See, e.g., INFT REPORT, supra note 8, at 106-07 (noting that the Biden Condition is not dispositive of ABM Treaty reinterpretation dispute because factual question remains regarding the asserted ambiguity of the ABM Treaty and its record).

${ }^{108}$ See 134 CoNG. Rec. S6724 (daily ed. May 26, 1988); Biden \& Ritch, supra note 83 , at 7 .

108134 Cong. REc. S6937 (daily ed. May 27, 1988). 
1, 1988. On June 10, President Reagan sent a letter to the Senate, officially denying the power of the Biden Condition. The President stated that he could not "accept any diminution claimed to be effected by such a condition in the constitutional powers and responsibilities of the Presidency."107 $\mathrm{He}$ added that "the principles of treaty interpretation recognized and repeatedly invoked by the courts may not be limited or changed by the Senate alone, and those principles will govern any future disputes over interpretation of this Treaty." 108 The letter reiterated a variant of the Sofaer Doctrine, that "Executive statements should be given binding weight only when they were authoritatively communicated to the Senate by the Executive and were part of the basis on which the Senate granted its advice and consent to ratification." 109 The President added that his Administration had no intention of diverging from the Senate's current understanding of the INF Treaty, so the difference in asserted powers would have no practical significance. $^{110}$

In response, Senator Byrd argued that the President's objections to the conditions of the Resolution of Ratification had come too late, saying, "[ $t]$ he President accepted the condition when he exchanged the instruments of ratification."111 Senator Nunn added that, "The Treaty, including this Condition, is now the supreme law of the land. And the President can no more change it with a letter than he can change any other law with a letter."112

The result of these exchanges is an impasse, with neither side giving ground on the specifics of the INF Treaty or on the more general questions of treaty interpretation and the Sofaer Doctrine. Conse-

${ }^{107} 24$ Weekly Comp. Pres. Doc. 780 (June 13, 1988).

${ }^{108} \mathrm{Id}$.

${ }^{109} I d$.

110 See id.

111 Strobel, INF Treaty Provision Triggers Reagan Balk, Wash. Times, June 13, 1988, at A6, col. 2. A subsequent response from Senator Pell, Chair of the Foreign Relations Committee, emphasized that with the Biden Condition, the Senate was seeking to preserve the Constitution, not to alter it. See Biden \& Ritch, supra note 83, at 78. that:

The Senate Foreign Relations Committee's report on the INF Treaty had noted

[T]he President may not act upon the Senate's consent without honoring this Condition. Nothing that he or his Administration does, by statement or action, whether before or after the act of ratification, can alter the binding effect of any condition which the Senate places upon its consent to treaty ratification. If the President brings the INF Treaty into force, the Condition takes effect.

INFT REPORT, supra note 8 , at 100 .

${ }^{112}$ Smith, President Disputes Hill on Treaties, Wash. Post, June 11, 1988, at A11, col. 1 . 
quently, the issue may be dormant, but only until the next treaty or controversy is debated. In Part II and III, I will try to establish the principles and mechanics of a better regime for resolving the deadlock.

\section{Applicable Principles of INTERNATIONAL AND CONSTITUTIONAL LAW}

We begin our search for a better approach to treaty interpretation by developing a framework of general principles from international law and United States constitutional law. ${ }^{113}$ One should note at the outset that very little is clear in this field. Experiential guidance is almost non-existent, ${ }^{114}$ as is court precedent. There is, accordingly, an unfortunate tendency for one's impressions of the legal principles to be clouded by judgments about the underlying policy choices. ${ }^{115}$

11 These two legal systems overlap more than is often realized. Some observers tend to focus on only one of the two legal aspects when analyzing treaty interpretation. See Lobel, The Limits of Constitutional Power: Conflicts Between Foreign Policy and International Law, 71 VA. L. REV. 1071 (1985). State Department Legal Adviser Abraham Sofaer's 1987 testimony regarding the Biden Resolution illustrates the importance and the difficulty of mastering the relationship between the concerns of international and domestic law. See supra note 83. Time magazine ran a story critical of Sofaer's celebrated remark that: "When [the Senate] gives its advice and consent to a treaty, it is to the treaty that was made, irrespective of the explanations it is provided." Joint Hearings, supra note 1 , at 130 . In response, Sofaer sent a letter to the editor asserting that his comment had been intended to refer only to the international, not the domestic, effect of Senate action. He wrote: " $\mathrm{My}$ testimony, however, was addressed to the effect of the Senate's ratification record on international obligations toward the other party to a treaty, not the obligations of the President toward the Senate under the U.S. constitutional structure." Sofaer, Letter to the Editor, supra note 83, at 10.

134 See 1987 SFRC REPORT, supra note 4, at 48 ("The Committee is aware of no instance in which a treaty was reasonably supposed by the Senate, when it consented to ratification, to mean one thing, and it was argued later by the Executive to mean something altogether different."); see also Joint Hearings, supra note 1, at 74 (discussion between Senator Adams and Senator Nunn) (no known precedent of executive reinterpretation of provisions fundamental to a treaty); $i d$. at 90 (statement of Professor Louis Henkin) (same). But see id. at 92 (statement of Senator Helms) ("I say to you that there have been a number of treaties where the administration has interpreted them differently down the line, and I did not hear any hue and cry about it."); id. at 94 (statement of Senator Pell) (agreeing with Senator Helms and providing the example of reinterpretations of treaties with the American Indians).

${ }_{115}$ See, e.g., Sofaer, supra note 71, at 1972 ("Many people have such intense attitudes toward SDI that they are unable or unwilling to treat questions of this Treaty's interpretation as other than a reflection of political ideology or strategic purpose."); $c f$. Joint Hearings, supra note 1, at 221 (discussion among Senator Biden, Senator Pell, and Sidney N. Graybeal, former ABM Treaty negotiator) (noting that Mr. Graybeal is one of the very few people who support the Strategic Defense Initiative, yet oppose the new interpretation of the ABM Treaty). 


\section{A. International Law Principles}

International law is, in many respects, an underdeveloped system, lacking both the comprehensiveness, and the obvious enforcement mechanisms available in the domestic law of advanced states. Skeptics have, not surprisingly, raised questions about its effectiveness. ${ }^{116}$

The modern system of international law, however, is far from nugatory. It embraces and promotes certain important shared principles, and consistently affects the way countries act and communicate in the international arena. It further provides a network of standards, as well as mechanisms for resolving disputes regarding international treaty obligations. ${ }^{117}$

For our purposes, four fundamentals of international law are directly relevant to the reinterpretation controversy, and serve as essential starting points for building a workable interpretation framework.

1. State sovereignty requires that the treaty that binds is the treaty that was negotiated and ratified.

A fundamental precept of international law is the concept that a sovereign state cannot ordinarily be bound to a treaty without its explicit assent; ${ }^{118}$ an international agreement may not lawfully bind, or alter the bonds upon, a state against its will. ${ }^{110}$ This means that the international implications of the terms of the ABM Treaty or of the INF Treaty are relatively enduring.

As a result of this precept, the ABM Treaty or INF Treaty that obligates the signatories is the treaty on which their minds originally met, and for which they exchanged signatures, and later instruments of

${ }^{116}$ See, e.g., D'Amato, Is International Law Really "Law"?, 79 Nw. U.L. REv. 1293, 1293 (1985) (questioning the status of international law as "true law," "quasilaw," or "near law").

117 See Restatement, supra note 2, at 16-17 ("International law is law like other law, promoting order, guiding, restraining, regulating behavior. States, the principal addressees of international law, treat it as law, consider themselves bound by it, attend to it with a sense of legal obligation and with concern for the consequences of violation.").

118 See Case of the S.S. "Lotus" (French Republic v. Turkish Republic), 1927 P.C.I.J. (Ser. A) No. 9, at 18 (Sept. 7) (international law emanates from the free will of states, and "[r]estrictions upon the independence of States cannot therefore be presumed").

${ }_{110}$ See id.; Sofaer, ABMT Reports, supra note 77, at S6671. A state can use a variety of mechanisms to manifest its assent to a treaty. See Vienna Convention, supra note 2 , arts. 11-17. A state may not invalidate a treaty on the grounds that its consent was given in violation of its own domestic processes, unless that violation of domestic law was manifest and concerned a rule of fundamental importance. See id., art. 46; Role of THE SENATE, supra note 2, at 52-55. 
ratification. The only internationally binding treaty is the one that the parties created at the time of ratification. This is true even if one or both later change their minds about what they could, or should, have agreed to during negotiations. Subsequent activities, of course, can serve as valuable evidence of what the parties originally did agree to, and can thereby aid the interpretation process, but they are insufficient to alter the basic textual obligations of either party. ${ }^{120}$

As a matter of international law, therefore, any United States treaty interpretation - whether "new" or "old" - is not binding on the Soviet Union. As a sovereign state the Soviet Union has the a priori right to determine (as does the United States) the extent to which it is willing to agree to any set of constraints upon itself. Neither party's subsequent unilateral statements, legislative records, or individual actions could alter the text or change the terms of the treaty; any effective amendment of the agreement always requires the affirmative action of both parties. ${ }^{121}$

In a crude sense, the analogy to domestic agent/principal law might be illustrative. In the usual circumstance, if an agent, armed with apparent authority to speak for a principal, makes an agreement within the scope of delegated authority, the principal may be bound by its terms, even if the principal doesn't like it. A fortiori, if the principal has ratified the agreement prior to its entry into force, the principal will be bound, even if the agent obtained the principal's concurrence by deceit. ${ }^{122}$ The principal has a cause of action against the disloyal agent, but the innocent third party still gets the benefit of the bargain that was

120 See Joint Hearings, supra note 1, at 403 (statement of Arthur W. Rovine, former State Department Assistant Legal Advisor).

121 See Vienna Convention, supra note 2, arts. 39-40; Restatement, supra note 2, § 334; see also Joint Hearings, supra note 1, at 3 (statement of Senator Biden) ("We cannot change the rules in the middle of the game simply by ordering lawyers of the State Department to find some loophole, as if they were high-paid counsel to some tycoon who wants to welsh on a bad deal.").

It is ironic that some on the political right, who have favored a "strict construction" of the Constitution and of major legislation, have come to advocate an expansive power of treaty reinterpretation, allowing considerable deviation from the understandings of the creators of the ABM Treaty. Conversely, some on the political left, who oppose an exclusive focus on the "original intention" of the drafters of the Constitution, now favor that close fealty to the authors of the ABM Treaty. See Joint Hearings, supra note 1, at 83 (statement of Professor Laurence H. Tribe); Joint Hearings, supra note 1, at 79-80 (statement of Professor Gordon Brewster Baldwin) (arms control treaty is not like contracts or like other, more detailed and narrow treaties - it requires continuing negotiations, not.fixed and indelible meaning); see also Perry, Judicial Activism, 7 HARv. J.L. \& PUB. POL'y 69, 69-73 (1984) (discussing the definition of "interpretation" and role of Judiciary regarding Constitution).

${ }_{122}$ Under certain circumstances, fraud or coercion may provide a basis for invalidating an international agreement. See Vienna Convention, supra note 2, arts. 49-51; RESTATEMENT, supra note $2, \S 331$. 
struck. ${ }^{123}$

In this context, the analogy suggests that the President (as agent) signs the treaty, and the Senate (as principal) consents to its ratification. Even if the President misrepresents the content of the agreement, the innocent third party (the Soviet Union) is entitled to rely upon the agreement that was duly negotiated. The problem in domestic political terms is how to convert the principal's hypothetical cause of action against the unfaithful agent, and transform it into something that is politically reliable. This is, however, a question of domestic law and politics, not of international obligations. ${ }^{124}$

\section{Treaties are to be interpreted in good faith.}

The basic "good faith" norm of treaty interpretation is reflected in Article 31 of the Vienna Convention on the Law of Treaties ${ }^{\mathbf{1 2 6}}$ and in the American Law Institute's Restatement (Third) of the Foreign Relations Law of the United States. ${ }^{126}$ The principle and its correlate, that the interpretation is to be "in accordance with the ordinary meaning to be given to the terms of the treaty in their context and in the light of its

123 See Restatement, supra note $2, \S 311$, reporters' note 4 ("Decisions of the Permanent Court of International Justice support the rule that a state is bound by apparent authority where lack of authority is not obvious to outside parties . . . ."); see also Joint Hearings, supra note 1, at 434 (letter from Professor Louis Henkin) (suggesting analogy to principal/agent law).

If the other state was not "innocent," but procured the treaty through the corruption or coercion of the agent, then the treaty may be voidable. See Vienna Convention, supra note 2, arts. 50-51.

124 See Coplin v. United States, 6 Cl.Ct. 115, 121 (1984) (noting that even if President acted ultra vires in agreeing to tax provisions of Panama Canal Treaty, the United States is bound by it), rev'd, 761 F.2d 688 (Fed. Cir. 1985), affd sub nom O'Connor v. United States, 479 U.S. 27 (1986); see also Joint Hearings, supra note 1, at 63 (statement of Senator Nunn) (if the President were to sign one contract with the Soviet Union, and a different contract with the Senate, there would be "profoundly disturbing constitutional implications, to say the least"); $c f$. id. at 73 (statement of Senator Biden) (comparing treaty creation to the sale of a house, in which both co-owners must sign the contract of sale and no secret arrangements between one co-owner and the purchaser will be valid against the other co-owner unless reflected in the contract). Of course, deliberate presidential misleading of Congress might be grounds for other political or legal sanctions, including perhaps impeachment.

${ }^{125}$ See Vienna Convention, supra note 2, art. 31. The Vienna Convention was concluded on May 23, 1969 and entered into force on January 27, 1980. The United States signed the Vienna Convention, but has not ratified it. Nevertheless, the Treaty is considered an authoritative statement regarding the law of treaties, and many of its provisions are binding upon all states, since they are declaratory of customary international law. See Role of THE SenATE, supra note 2, at 41; see also E. YAMBrusic, TREATY INTERPRETATION: THEORY AND REALITY 169 (1987) (discussing principles of treaty interpretation in international practice).

${ }^{126}$ See Restatement, supra note $2, \S 321$. 
object and purpose,"127 are essential ingredients in the creation of a viable pattern of international public and private business. Reference to "good faith" does not by itself resolve all treaty interpretation questions, but does suggest certain standards. ${ }^{128}$

The Vienna Convention and the Restatement further specify the sources to be consulted regarding treaty interpretation matters - including first and foremost, the actual text in question. Any associated instruments, subsequent practices, or other such materials. are also reviewed, in accord with a rough hierarchy established by international law. ${ }^{128}$

It is important to note that international agreements are characterized by an inherent degree of ambiguity and indeterminacy that makes interpretation challenging. ${ }^{130}$ While every word of the treaty text has

127 Vienna Convention, supra note 2, art. 31; see also RESTATEMENT, supra note 2, § 325; cf. Factor v. Laubenheimer, 290 U.S. 276, 293 (1933) (arguing that obligations of a treaty should be liberally construed, so as to effect the apparent intention of the parties); Jordan v. Tashiro, 278 U.S. 123, 128 (1928) (declaring that accepted principles require the court to give the terms of a treaty a liberal rather than a narrow interpretation); Asakura v. City of Seattle, 265 U.S. 332, 342 (1924) ("Treaties are to be construed in a broad and liberal spirit, and, when two constructions are possible, one restrictive of rights that may be claimed under it and the other favorable to them, the latter is to be preferred.").

${ }^{128}$ Perhaps the most basic principle of the law of treaties is the maxim pacta sunt servanda (treaties must be kept). See Vienna Convention, supra note 2, art. 26. This principle requires that international obligations take precedence over contrary national laws and that statutory, or even constitutional, barriers to a treaty are insufficient to excuse a party's non-performance.

128 See Vienna Convention, supra note 2, arts. 31-32; Restatement, supra note $2, \S 325$. United States jurisprudence departs somewhat from that of the international community as reflected in the Vienna Convention. That is, the Vienna Convention places a special primacy upon the "ordinary meaning" of the text of a treaty, requiring a finding that the text is obscure or ambiguous before "supplementary means of interpretation" such as the negotiating record of the treaty (traveaux preparatoires) may be consulted. See Vienna Convention, supra note 2, art. 32; Jurisdiction of the European Commission of the Danube (Galatz v. Braila), 1927 P.C.I.J. (Ser. B) No. 14, at 31 (Dec. 19, 1926).

United States courts, on the other hand, are generally more concerned with the parties' intentions, and more willing to look outside the four corners of the treaty document in order to adduce its meaning. See, e.g., Laubenheimer, 290 U.S. at 294 (court may look beyond the words of a treaty to ascertain its meaning); Coplin v. United States, 761 F.2d 688, 691 (Fed. Cir. 1985) (court should look beyond literal language of treaty and examine diplomatic exchanges in order to adduce the parties' intentions), aff'd, 479 U.S. 27 (1986); RESTATEMENT, supra note 2, § 325, comment g. But see Joint Hearings, supra note 1 , at 396 (statement of Abram Chayes and Antonia $H$. Chayes) (differences between United States practice and international law practice regarding the treatment of negotiating history in treaty interpretation are relatively minor, a matter of nuance rather than a fundamental divergence).

130 See, e.g., HFAC ABM Hearings, supra note 56, at 23 (statement of Ambassador Gerard Smith) ("It would be a unique episode in international negotiations to have a completely unambiguous record, especially in a bargaining process requiring $2 \frac{1 / 2}{2}$ years."); G. DUFFY, supra note 41, at 2 (balancing conflicting interpretations of agree- 
received the assent of the parties, there will always linger a variety of potential problems: unanticipated technological advances; inadvertent (or deliberate) loopholes; and, in the crush of negotiations over critical issues, simple failure to think through all the eventualities of all the possible details. ${ }^{131}$

The negotiating history can be an important contributor in attempting to adduce the parties' intentions, importing into any textual ambiguities a reflection of their mutual object and purposes. ${ }^{132}$ But the negotiating history of a treaty is usually far less tangible and less reliable than, for instance, the legislative history of a congressional enactment. ${ }^{133}$ This is because, in the international arena, there are ordinarily no "recording secretary," no official minutes, and no agreed committee reports to convey consensus understandings. ${ }^{134}$

The negotiating history of an arms control treaty is particularly uneven and incomplete. It consists principally of the following elements: 1) a relatively small number of formal "plenary statements" that are read and later exchanged by ambassadors in order to introduce major elements or to signal important changes in negotiating posture; ${ }^{135} 2$ ) draft treaty texts prepared during the course of negotiations; ${ }^{136}$ and 3 ) a

ments is difficult in the international sphere).

${ }^{131}$ See. e.g., Joint Hearing, supra note 1, at 11 (statement of Senator Thurmond) ("Diplomatic negotiations are ambiguous by nature. This should be expected when a country whose legal traditions are based on English common law negotiates with a totalitarian dictatorship to achieve diametrically opposite ends."); see also 133 CoNG. REC. S3172 (daily ed. Mar. 13, 1987) (statement of Senator Nunn) (acknowledging that there are ambiguities in the record of the ABM Treaty and wishing that the negotiators had achieved a higher level of clarity and precision in drafting, but noting, "[o]f course, as we in the Senate well know, writing clear law is a worthy goal but one not easily attained.").

${ }_{132}$ Here again, there is a slight, but perhaps significant, difference in interpretation methodology between international and United States courts. The Vienna Convention focuses attention on "the ordinary meaning" of the terms of the text, in light of their object and purpose. See Vienna Convention, supra note 2, art. 31. Most United States courts, however, would look first at the intention of the parties, with the ordinary meaning of the words being one factor useful in adducing their intentions. See RESTATEMENT, supra note $2, \S 325$, reporter's note 4 .

${ }_{133}$ See Joint Hearings, supra note 1 , at 198 (statement of Antonia Chayes, former Undersecretary of the Air Force) (noting that a negotiating record is very extensive and confusing, "not at all neat like the legislative record before the Senate"); 133 Cong. Rec. S6810 (daily ed. May 20, 1987) (statement of Senator Nunn) (the negotiating record "materials simply do not compare in quality to the debates and reports normally relied upon for interpretation of legislation").

134 See R. GARTHOFF, supra note 70, at 30 n.4; McNeill, U.S.-USSR Nuclear Arms Negotiations: The Process and the Lawyer, 79 AM. J. INT'L L. 52, 56 (1985).

135 A plenary meeting is the most formal device for the arms control negotiations, providing the occasion for important explanatory remarks and the tabling of proposed texts. See McNeill, supra note 134, at 56.

${ }^{138}$ Typically, each delegation tables its own version of the text of each article of a proposed treaty and, at some point, the respective versions are merged into a "joint 
vast quantity of unilateral "memoranda of conversations" ("memcons") ${ }^{137}$ that are written after the fact by members of the delegation to summarize a long or short, formal or informal, discussion held with a member of another delegation. ${ }^{138}$

The corpus of the negotiating record - which grows irregularly and inconsistently over the years, reflecting the piecemeal fits and starts of the negotiations ${ }^{139}$ - is itself, therefore, often less clear, as well as harder to assemble and to index, ${ }^{\mathbf{1 4 0}}$ than we would like. Despite the inadequacies of the various elements of the record, international law dictates the order and relative weight to be given to sources when a question of treaty interpretation arises.

3. The critical time for measuring the parties' intentions and understandings is the time at which the treaty is made.

A third principle may be derived from the first two: when inspecting the parties' interpretations or understandings regarding their new treaty obligations, international law directs foremost attention to the time when the treaty was "made," that is, the time when the instruments of ratification were exchanged. ${ }^{141}$

It is this period that represents the parties' critical "meeting of the

draft text" reflecting areas of agreement and disagreement. See id. at 59.

${ }^{137}$ Delegation members encounter members of other nations' delegations quite frequently and report back to their national capitals via memcons regarding the substance of the conversations. See $i d$. at 57 . There is a slogan that "no one ever loses in his own memcons," meaning that these unilateral reports, never seen or vetted by the public or by members of the other delegation, are inherently one-sided accounts of the conversations. See 133 Cong. REc. S6810 (daily ed. May 20, 1987) (statement of Senator Nunn).

${ }^{138}$ See Joint Hearings, supra note 1 , at 117 (statement of Senator Biden) (describing the negotiating record of a treaty as "an amalgam - of indeterminate size - of translators' notes, memcons, and internal memorandums"); see also 133 ConG. REC. S6810 (daily ed. May 20, 1987) (statement of Senator Nunn) (negotiating record is "a variety of documents of uneven quality").

139 See, e.g., Joint Hearings, supra note 1, at 377 (statement of Professor Abram Chayes) (treaty negotiations extend over many months, negotiating positions shift, and drafters have to develop varying language, so no one piece of the history, taken out of context, can reveal the treaty's meaning).

${ }_{140}$ See Joint Hearings, supra note 1, at 117 (statement of Senator Biden); id. at 151 (colloquy between Senator Kerry and Abraham D. Sofaer, State Department Legal Adviser); id. at 198 (statement of Antonia Chayes, former Undersecretary of the Air Force); see also Glennon, supra note 81, at 917 (no guaranty that even now the government could assemble a complete set of the disjointed documents constituting the negotiating record of the ABM Treaty).

${ }^{141}$ The Vienna Convention reflects a variety of mechanisms through which a state may express its intention to be bound to a treaty: upon signature, upon exchange of later instruments, and more. See Vienna Convention, supra note 2, arts. 11-17. As noted below, infra note 143 and accompanying text, virtually all important agreements regarding arms control are designed to be effective only upon ratification. 
minds" because the negotiators' earlier understandings (including even those held at the time of signature of the treaty) may be modified by intervening events, such as either state's domestic process of treaty approval. Conversely, the subsequent positions of either side are inherently unilateral and are often affected in a self-serving fashion by the emerging controversy itself - they do not reflect a mutually-agreed resolution of any questions.

This is not to suggest that an international agreement is a permanent straightjacket. Indeed, the parties to a treaty may freely modify it by a subsequent amendment or by mutually-agreed practice. ${ }^{142}$ But until they elect to do so by consensus, the treaty that was made - as evident in their shared interpretation of it at that time - remains binding under international law.

\section{International law contemplates a variety of treaty-making processes.}

International law affords a great deal of freedom in most aspects of treaty-making, so countries may adapt the procedures and content of the documents to serve their foreign policy objectives and still be faithful to their peculiar domestic political processes. For example, negotiating delegations may be established in a variety of ways at differing levels of authority. Similarly, the parties may write a treaty that is designed to come into force immediately upon signature, or they may require some form of prior review by home authorities. ${ }^{143}$ In the same way, the parties may intend a treaty to be "self-executing," creating international and domestic legal obligations as soon as it enters into force. Or, conversely, they may intend the treaty obligations to commit the parties only to undertake other future action without which the treaty is ineffective as municipal law. ${ }^{144}$ Treaties with any combination

142 See Restatement, supra note $2, \S 115$, comment d.

${ }^{143}$ See id.; Vienna Convention, supra note 2, arts. 11-17. Modern arms control agreements virtually always require subsequent political approval and ratification. The role of the United States Senate, as an independent check upon the actions of the Executive, is unusual in international practice. See N. Galvo-Goller \& M. Calvo, supra note 33, at 4 . In the Soviet Union, for example, domestic ratification is a mere formality after the executive has made its decision. Id. at 87, 145-79.

144 See Foster v. Neilson, 27 U.S. (2 Pet.) 253 (1829). The Court stated:

Our Constitution declares a treaty to be the law of the land. It is, consequently, to be regarded in courts of justice as equivalent to an act of the legislature, whenever it operates of itself, without the aid of any legislative provision. But when the terms of the stipulation import a contract, when either of the parties engages to perform a particular act, the treaty addresses itself to the political, not the judicial department; and the legislature must execute the contract, before it can become a rule for the court. 
of these characteristics are acceptable under international law. Interpreting a treaty on these matters is essentially a question of discovering or deducing the parties' intentions in the particular document in question.

International law has also created a jurisprudence surrounding "reservations." A reservation is a nation's unilateral attempt, after the negotiations, to modify the terms or import of the treaty. ${ }^{145}$ Almost any type of reservation may be registered at the time of signing or ratifying a treaty, provided that reservation is neither prohibited by the treaty nor incompatible with its object and purpose. ${ }^{146}$ The Vienna Convention specifies detailed procedures for registering a reservation ${ }^{147}$ and explicates the legal effects of reservations, objections to reservations, and acceptances of reservations. ${ }^{148}$ The network of resulting obligations may become quite complex in a multilateral treaty, but conceptually, inter-

Id. at 314; see also Role of THE SenATe, supra note 2, at 66-70; Restatement, supra note $2, \S 111$ comment $\mathrm{h}$. A treaty may be partially self-executing. In some instances (such as treaties imposing tax obligations or requiring the expenditure of public funds), the United States Constitution would require provisions of an agreement to be non-self-executing, so that congressional legislation would be required for implementation. See id., $\S 111$, comments $h$, i.

Many provisions of modern arms control agreements are non-self-executing, and subsequent legislation is contemplated. See, e.g., Biological Weapons Convention, supra note 21, art. IV ("Each State Party to this Convention shall, in accordance with its constitutional processes, take any necessary measures to prohibit and prevent the development, production, stockpiling, acquisition, or retention of the agents, toxins, weapons, equipment and means of delivery specified in article I of the Convention, within the territory of such State, under its jurisdiction or under its control anywhere.").

One of the controversial issues delaying United States ratification of the Genocide Convention was the question of whether the Treaty would be considered self-executing. The Foreign Relations Committee concluded that it would not be and also recommended a declaration to underscore that point. See Constitutional Issues Relating to the Proposed Genocide Convention: Hearing before the Subcomm. on the Constitution of the Senate Comm. on the Judiciary, 99th Cong., 1st. Sess. 41 (1985) [hereinafter Genocide Convention Hearings] (written responses of Professor John Norton Moore); Senate Foreign Relations Comm., In't'l Convention on the Prevention and Punishment of the Crime of Genocide, S. Exec. Doc. No. 2, 99th Cong., 1st Sess. 26 (1985) [hereinafter Genocide Convention ReporT].

145 See Vienna Convention, supra note 2, arts. 19-23; Restatement, supra note $2, \S \S 313-14$; see also Reservations to the Convention on the Prevention and Punishment of the Crime of Genocide, 1951 I.C.J. 15, 15-20 (written statement of the Organization of American States) (describing the legal effects of reservations and of objections to reservations). The Vienna Convention defines a reservation as a unilateral statement whereby a party to a treaty "purports to exclude or to modify the legal effect of certain provisions of the treaty in their application to that State." Vienna Convention, supra note 2 , art. 1 (d).

148 See Vienna Convention, supra note 2, art. 19; Restatement, supra note 2, $\S 313(1)$.

147 See Vienna Convention, supra note 2, art. 23.

148 See id., arts. 20-22; RESTATEMENT, supra note 2, §§ 313-14. 
national law has no difficulty dealing with parties' contemporaneous expressions of conflicting interpretations or understandings. ${ }^{149}$

The foregoing analysis suggests that relevant standards of international law permit the United States a substantial, but not unlimited, range of freedom regarding the creation and enforcement of treaties. International practice allows nations to shape their international obligations largely as they see fit in order to serve the participants' shared object and purposes without stultifying red tape. On the other hand, the principles of international law are not infinitely malleable. In particular, no state is allowed to impose its will upon its negotiating partners, and no state is authorized to effectuate unilateral changes in agreed treaty terms. States "change their minds" with regularity in regard to the wisdom and desirability of their international commitments, but they may lawfully alter the existing treaties only by mutual consent.

\section{B. Constitutional Principles of Treaty Interpretation}

1. The Supremacy Clause establishes that treaties and statutes are equivalent under the Constitution.

Article VI ${ }^{160}$ states that the Constitution is superior to either legislation or treaty ${ }^{151}$ and also provides that the latter two types of instruments are of equal dignity. In the event of a conflict between legislation and a treaty, the more recent document will prevail. ${ }^{\mathbf{1 6 2}}$ If a statute is

149 See Gamble, Reservations to Multilateral Treaties: A Macroscopic View of State Practice, 74 AM. J. InT'L L. 372, 372-73 (1980).

${ }^{180}$ U.S. ConsT. art. VI, cl. 2 ("This Constitution, and the Laws of the United States which shall be made in Pursuance thereof; and all Treaties made, or which shall be made, under the Authority of the United States, shall be the supreme Law of the Land ....").

151 See e.g., Reid v. Covert, 354 U.S. 1, 16-17 (1957) ("[N]o agreement with a foreign nation can confer power on the Congress, or on any other branch of Government, which is free from the restraints of the Constitution. . . . The prohibitions of the Constitution were designed to apply to all branches of the National Government and they cannot be nullified by the Executive or by the Executive and the Senate combined."); Geofroy v. Riggs, 133 U.S. 258, 267 (1890) ("It would not be contended that [the treaty power] extends so far as to authorize what the Constitution forbids."); L. Henkin, Foreign Affairs and the Constrtution 137-56 (1972).

In considering the controversial Genocide Convention, the Foreign Relations Committee concluded that there might be a conflict between the Treaty and the United States Constitution and recommended a reservation to clarify that the obligations of the Constitution would prevail. See GeNOCIDE Convention REPORT, supra note 144, at 19-20. The minority commentators argued that this reservation was unnecessary, since for purposes of domestic law, the Constitution would overrule a treaty in any event, and the "self-judging" nature of the reservation was politically unwise. See id. at 3031.

152 See, e.g., Cook v. United States, 288 U.S. 102, 119 (1933) (tariff treaty with Great Britain superseded prior inconsistent statute); The Chinese Exclusion Case, 130 
subsequent to a treaty, for example, it can require the United States to take actions that violate the treaty. ${ }^{163}$ Conversely, if the treaty is second in time, it can effectively supersede a prior inconsistent statute, at least to the extent that the treaty is intended to be self-executing. ${ }^{164}$ In addition, American domestic law can readily supplement the obligations of a treaty, imposing tougher restrictions on the United States than those compelled by our negotiating partners under the treaty. ${ }^{155}$

U.S. 581, 602 (1889) (statute excluding aliens from United States takes precedence over earlier treaty); Whitney v. Robertson, 124 U.S. 190, 194 (1888) ("By the Constitution a treaty is placed on the same footing, and made of like obligation, with an act of legislation. . . . but if the two are inconsistent, the last one in date will control the other, provided always the stipulation of the treaty on the subject is self-executing."); Head Money Case, 112 U.S. 580, 597-99 (1884) (congressional enactment can supersede a treaty).

${ }^{153}$ The United States then would be liable internationally for breach of the treaty's obligations and could not effectively assert as a defense the fact of domestic process that mandated the violation. See RESTATEMENT, supra note $2, \S 115$, comment b. Courts will attempt to avoid an interpretation of a statute that will conflict with international law. See Trans World Airlines v. Franklin Mint, 466 U.S. 243, 251-53 (1984) (treaty will not be deemed abrogated by subsequent legislation unless congressional intent is clear); Murray v. The Schooner Charming Betsy, 6 U.S. (2 Cranch) 64, 118 (1804) ("[A]n act of Congresss ought never to be construed to violate the law of nations, if any other possible construction remains .... .).

184 See Restatement, supra note 2, § 115; see also Cook v. United States, 288 U.S. 102, 119 (1933) (self-executing treaty modified statutory territorial limitations for search and seizure of British vessels suspected of smuggling intoxicating liquors into the United States); Johnson v. Browne, 205 U.S. 309, 321 (1907) (later treaty will not be regarded as repealing an earlier statute by implication unless the two documents are absolutely incompatible); United States v. The Schooner Peggy, 5 U.S. (1 Cranch) 103, $106-109$ (1801) (a treaty is the supreme law of the land superseding incompatible legislation).

${ }_{155}$ These heightened constraints are not binding upon another nation unless it unilaterally decides to follow suit. Moreover, they can be changed at will by the United States without international law implications. As long as the United States complies with its treaty obligations, other countries have no particular legal interest in whatever additional constraints are self-imposed by legislation, court order, or any of the myriad of other devices available for making domestic law in this country. See Joint Hearings, supra note 1, at 127 (statement of Abraham D. Sofaer, State Department Legal Adviser). For example, the ABM Treaty, supra note 7, permitted the United States and the Soviet Union to deploy two missile defense systems each. This was later reduced to one site per country by a subsequent protocol. See Protocol to the ABM Treaty, supra note 58, at 161. The Soviet Union has deployed, and periodically upgraded, its one permitted site near Moscow. The United States, on the other hand, constructed, but promptly deactivated and decommissioned, its one site near Grand Forks, North Dakota. See generally ACDA Treaty Book, supra note 14, at 144.

Sofaer told the Committee that:

These [committee reports] and the statements in the Senate in the ratification proceedings are, in fact, purely domestic documents of no concern to other parties except where, in a particular case, the U.S. Government acts formally to communicate such matters to the other side. In such a case, an interpretation communicated to the other party, while not binding, could have probative weight in determining what the parties intend. . .

Joint Hearings, supra note 1, at 127; see also Role of THE SENATE, supra note 2, at 
The principles governing United States treaties will apply, with substantially the same effect, to international agreements other than treaties. ${ }^{158}$ "Executive agreements," whether fashioned by the Executive alone, pursuant to a prior treaty, or with the approval of the Congress, have essentially the same status under both international and domestic law as treaties. ${ }^{157}$ Even though their constitutional basis is different, the two types of documents have become almost interchangeable. ${ }^{158}$

A final observation in this context is that international law,

55-56 (unilateral statements and declarations of intent not binding). But see Nuclear Tests Case (Australia v. France), 1974 I.C.J. 253, 269 (unilateral declarations by France that it would discontinue atmospheric nuclear testing held to be legally binding); Nuclear Tests Case (New Zealand v. France), 1974 I.C.J. 457, 472 (same); N. Calvo-Goller \& M. Calvo, supra note 33, at 187 (noting that unilateral declarations can create binding legal rights and obligations in some circumstances).

168 The Senate's advice and consent power affords it a special role in the evaluation of treaties, but the House of Representatives also frequently expresses a great interest, even when the international agreement does not come directly before it. See generally $H F A C A B M$ Hearings, supra note 56 , at 1 (meeting of House Subcommittee to discuss executive policy with respect to the ABM Treaty); House ForEIGN AFFAIRS Comm., Agreement on the Limitation of Strategic Offensive Weapons, H.R. REP. 1324, 92d Cong., 2d Sess. 5 (1972) (response to executive request for House recommendation of ABM Treaty).

157 See United States v. Belmont, 301 U.S. 324, 330-31 (1937); B. Altman \& Co. v. United States, 224 U.S. 583, 600-01 (1912); Role of THE Senate, supra note 2, at 70-87 RESTATEMENT, supra note $2, \S 303$.

${ }^{188}$ See Circular 175 Procedures: Treaties and Other International Agreements in 11 Foreign Affairs Manual, Chapter 700 (rev. ed. Oct. 25, 1974), reprinted in Role of The Senate, supra note 2, at 248-70 [hereinafter Circular 175]; L. HeNKIN, supra note 151, at 173-87. Executive agreements have become much more common than treaties. By 1983, the United States was party to 966 treaties and 6571 executive agreements. See Role of THE Senate, supra note 2, at 38-39.

The Case/Zablocki Act, Pub. L. No. 92-403, 86 Stat. 619 (1972) (codified as amended at 1 U.S.G. $\S 112 \mathrm{~b}(1982)$ ), requires that all executive agreements be transmitted to the Congress within 60 days of execution, to prevent the creation of "secret agreements." See id.

One special aspect of United States law regarding executive agreements in the field of arms control specifies that any steps "that will obligate the United States to disarm or to reduce or to limit the Armed Forces or armaments of the United States" may be taken only pursuant to the treaty power or to affirmative legislation of the Congress. Arms Control and Disarmament Act of 1961, Pub. L. No. 87-297, § 33, 75 Stat. 634 (codified as amended at 22 U.S.C. $\$ 2573$ (1982)). Where the Executive concludes an international agreement (such as the SALT I Interim Agreement on Strategic Offensive Arms) in the form of an executive agreement, rather than a treaty, this statute contemplates that the agreement is to be approved by a majority of each House of Congress. It is arguable, of course, that the purported restrictions of this statute would be invalidated as an unconstitutional attempt to impinge upon the President's constitutional ability to conclude an executive agreement that limits the armed forces of the United States, based upon the Executive's power to conclude "sole" executive agreements. See RESTATEMENT, supra note 2 , § 303, reporters' note 8. This question has never been tested, however, because the only major arms control accord that was cast as an executive agreement (the SALT I Interim Agreement) was submitted to both Houses of Congress. 
whether produced by custom or by agreement of the United States, is "incorporated" into American law. ${ }^{159}$ Like treaties, customary international law has come to be considered as "supreme" federal law, overruling contrary state statutes as well as inconsistent prior congressional enactments. ${ }^{160}$

\section{There is a substantial, although not complete, deference to the}

Executive in matters of international policy.

In recognition of the singular demands of international life, American jurisprudence has come to acknowledge a unique relationship among the powers of the federal and state governments and within the three branches of the national leadership. Ordinarily, the federal government is deemed to possess near total authority to speak for the nation as a whole, and the President is customarily accorded unusual latitude to speak for the federal government in the foreign policy sector. ${ }^{\mathbf{1 0 1}}$ Under this arrangement, the President, as possessor of "the executive power" under the Constitution, ${ }^{162}$ and as Commander in Chief, ${ }^{\mathbf{1 6 3}}$ has extraordinary authority to act as the "sole organ"164 of the United States in dealings with other sovereigns. ${ }^{165}$

158 See, e.g., The Paquete Habana, 175 U.S. 677, 700 (1900) ("International law is part of our law, and must be ascertained and administered by the courts of justice of appropriate jurisdiction, as often as questions of right depending upon it are duly presented for their determination."); Filartiga v. Pena-Irala, 630 F.2d 876, 887 (2d Cir. 1980) (international customary law prohibiting torture is binding inside United States).

160 See L. HENKIN, supra note 151, at 221-24; REstatement, supra note 2, $\S 111$. Customary international law is considered equivalent to federal common law of the United States, cognizable in federal and state courts. See id., $\S 111$, comment d, reporters' note 3 .

${ }_{161}$ See, e.g., Zschernig v. Miller, 389 U.S. 429, 432 (1968) (Constitution bars "an intrusion by the State into the field of foreign affairs which the Constitution entrusts to the President and to Congress"); United States v. Belmont, 301 U.S. 324, 331 (1937) ("In respect of . . . our foreign relations generally, state lines disappear. As to such purpose the State. . .does not exist."); The Chinese Exclusion Case, 130 U.S. 581, 604-09 (1889) (national government has power to direct foreign affairs); L. HENKIN, supra note 151, at 15 ("Foreign affairs are national affairs," and the national government, not the states, conducts them). Under the Constitution, States of the United States may not make treaties and may make "agreements" or "compacts" with other nations only with the consent of Congress. See U.S. CoNST. art. I, $\S 10$, cls. 1, 3.

162 See U.S. ConsT. art. II, § 1, cl. 1.

${ }_{183}$ See id., § 2, cl. 1.

184 United States v. Curtiss-Wright Export Corp., 299 U.S. 304, 319 (1936) (quoting speech of Representative John Marshall).

${ }_{166}$ See Dames \& Moore v. Regan, 453 U.S. 654, 678-88 (1981); Belmont, 301 U.S. at 330 . As the Belmont Court stated; "Governmental power over external affairs is not distributed, but is vested exclusively in the national government. And in respect of what was done here [settling claims with the Soviet Union], the Executive had authority to speak as the sole organ of that government." Id.; see also Sullivan v. Kidd, 
Executive primacy does not require automatic and complete deference from the other branches in every controversy touching international affairs. Both the Congress and the Judiciary have roles to play in shaping the international affairs of the United States, and none of the three branches can count on having "the last word" on these issues. ${ }^{168}$ Many of Congress's enumerated powers, such as the commerce clause, ${ }^{167}$ the power to declare war ${ }^{168}$, and the Senate's opportunity to advise and consent to treaties, ${ }^{169}$ concern foreign affairs. Moreover, there are additional situations where Congress and the President share, to some imprecisely-defined extent, the power to influence foreign affairs. ${ }^{170}$

Justice Jackson's famous triptych in the 1952 Steel Seizure Case $^{171}$ is still the leading expression of the potential overlap between executive and legislative functions. ${ }^{172}$ There, he identified three scenarios of varying shared powers between the Executive and Congressional

254 U.S. 433, 442 (1921) (noting that the Executive is charged with the supervision of foreign affairs); A. SofaER, WAR, Foreign AfFairs aNd Constitutional Power 127-29, 376-79 (1976) (developing the historical basis for Presidential control over foreign affairs); Henkin, Foreign Affairs and the Constitution, 66 FoREIGN AFF. 284, 297-99 (1987) (noting that developments over the years have firmly established the President's exclusive control over diplomacy).

${ }^{166}$ See, e.g., Role of THE Senate, supra note 2, at 8-9 (describing steps in making a treaty or executive agreement); $i d$. at 25-28 (describing the evolution of the treaty power during the Constitutional Convention). As Alexander Hamilton described the foreign relations power:

The power in question seems therefore to form a distinct department, and to belong, properly, neither to the legislative nor the executive. The qualities elsewhere detailed as indispensable in the management of foreign negotiations, point out the Executive as the most fit agent in those transactions; while the vast importance of the trust, and the operation of treaties as laws, plead strongly for the participation of the whole or a portion of the legislative body in the office of making them.

The Federalist No. 75, at 467 (A. Hamilton) (H. Lodge ed. 1888); see also A. SOFAER, supra note 165 , at 127-29, 376-79 (describing early practice of shared legislative and executive powers); The FEderalist No. 64, supra, at 401 (J. Jay) (entrusting the President and the Senate with the treaty-making power reflects the desire that treaties be formed by "those who best understand our national interests").

${ }_{167}$ See U.S. ConsT. art. I, $\S 8$, cl. 3.

168 See id., art. I, § 8, cl. 11 .

169 See id., art. II, $\S 2$, cl. 2.

170 See L. Henkin, supra note 151, at 32 ("As they have evolved, the foreign relations powers appear not so much 'separated' as fissured, along jagged lines indifferent to classical categories of governmental power: some powers and functions belong to the President, some to Congress, some to the President-and-Senate; some can be exercised by either the President or the Congress, some require the joint authority of both.").

${ }_{171}$ Youngstown Sheet \& Tube Co. v. Sawyer, 343 U.S. 579, 635-37 (1952) (concurring opinion).

${ }_{172}$ See, e.g., Dames \& Moore v. Regan, 453 U.S. 654, 668-69 (1981) (citing Justice Jackson's tripartite analysis of executive power). 
Branches. ${ }^{173}$ Treaty law is a classic example of Justice Jackson's second category, the "twilight zone" of concurrent, uncertain executive and legislative authority and shared functions. ${ }^{174}$ This overlap obtains not only in the making of treaties, but also in their subsequent interpretation.

\section{a. Shaping Treaties}

At the outset of the process of creating a new treaty, the President clearly has the lead responsibility for conducting the international negotiations, although the participation of members of Congress in this phase seems to be increasing. ${ }^{175}$ The action next shifts to the Senate, which independently considers the treaty during the advice and consent period, and may attach various conditions, including reservations that may mandate renegotiation. ${ }^{\mathbf{1 7 8}}$ Once the Senate has given its consent,

${ }^{173}$ First, "[w]hen the President acts pursuant to an express or implied authorization of Congress, his authority is at its maximum . . . Youngstown Sheet $\&$ Tube, 343 U.S. at 635. Second, "[w]hen the President acts in the absence of either a Congressional grant or denial of authority, . . . there is a zone of twilight in which he and Congress may have concurrent authority, or in which its distribution is uncertain." Id. at 637. Third, "[w]hen the President takes measures incompatible with the expressed or implied will of Congress, his power is at its lowest ebb, for then he can rely upon only his own constitutional powers, minus any constitutional powers of Congress over the matter." Id.

174 See id.

${ }^{175}$ The modern practice of the Executive Branch regarding the negotiation of treaties is outlined in Circular 175, supra note 158, at 248-70. The very early practice under the Constitution was for the President to consult the Senate in detail about proposed treaty provisions and to solicit the Senate's advice on specific matters while the negotiations were ongoing. This proved unsatisfactory since the legislative body as a whole proved too cumbersome to provide timely, specific advice to the negotiations. See Role of THE SENATE, supra note 2, at 30-34; see also A. SofaER, supra note 165, at 95-97 (discussing President Washington's decision to conduct negotiations without the Senate's ongoing advice).

During the SALT II and START negotiations, various members of Congress came to play roles as participants on the United States negotiating delegation, serving as policy advisors and as legislators directing national policy. See, e.g., McNeill, supra note 134, at 63-64 (suggesting that congressional involvement will grow in the future as a result of the role played by members of the legislature in START and SALT II).

It also should be noted that the Senate plays another, indirect role in treaty negotiation through the power to confirm presidential policy-making appointees, diplomats, and arms control negotiators. See U.S. CoNST. art. I, § 2, cl. 2; 22 U.S.C. § 2567 (1982) (creating the position of Special Representative for Arms Control and Disarmament Negotiations, with presidential appointment subject to Senate advice and consent).

${ }_{178}$ A variety of mechanisms is available for the Senate to express itself regarding the content of a treaty. An amendment is a proposed change in the text of the document itself. A reservation is a qualification or stipulation that changes United States treaty obligations without necessarily changing the text. An understanding is an interpretive statement made for the purpose of clarifying or elaborating, rather than changing, the provisions of the agreement. A declaration is a statement of the Senate's position or opinion on matters related to the treaty, but not its specific provisions. The distinctions 
the President again must take the initiative in deciding whether to "make" the treaty by exchanging the instruments of ratification. The President may decline to ratify the agreement if, for example, he decides that the Senate's declarations or other actions regarding it are unacceptable. ${ }^{177}$

Once the treaty has been made, the President, as Chief Executive, bears the responsibility for faithfully implementing it. ${ }^{178}$ Congress, however, controls the purse-strings, as well as the power to pass necessary implementing legislation, ${ }^{\mathbf{1 7 9}}$ and the courts also have an integral

among these four devices may be elusive; the effect of the particular proviso, rather than its label, is what matters. See Role of THE SENATE, supra note 2, at 109-12; SFRC SALT II REPORT, supra note 35, at 34; see also L. HENKIN, supra note 151, at $382 \mathrm{n} .31$ (noting that the Senate sometimes refers collectively to "understandings and reservations" without specifying which is which).

The Senate sometimes has made fine discriminations among the various types of provisos. For example, in ratifying the Genocide Convention, the Senate gave its consent subject to two reservations, five understandings, and one declaration. See GeNoCide Convention RePort, supra note 144, at 15. "Each type of proviso makes a different statement about the international legal obligation the United States would assume by ratifying the Genocide Convention; each can also have different consequences for the relationship between the United States and the other parties to the Convention." Id.

During hearings concerning the INF Treaty, some witnesses urged the Senate to consider reservations that would require renegotiation of the Treaty, rather than simply voting yes or no on so-called "killer amendments" which could scuttle the entire document. See NATO Defense Hearings, supra note 76, at pt. 3, 142 (comments of former Assistant Secretary of Defense Richard Perle). "The Senate has a role to play. It is a second chance in our constitutional structure that most of the time is a damn nuisance because Presidents cannot make commitments until after those commitments have been ratified by the Senate." Id.

The first occasion on which the Senate gave only conditional approval, requiring renegotiation of a treaty before the final advice and consent, was the Treaty of 1797 with Tunis. See Role of THE SEnATe, supra, note 2, at 36. The first occasion on which the other party refused to renegotiate, and the Treaty therefore failed to enter into force, was the King-Hawksbury Convention of 1803 with Great Britain. See id.

The Senate used to be known as "the graveyard of treaties," but, in fact, the overwhelming proportion of treaties are approved relatively expeditiously and without changes. Only four treaties this century have been voted down by the Senate. See RolE OF THE SENATE, supra note 2, at 103, 117-18; see also SFRC SALT II REPORT, supra note 35, at 28 (noting that 1789, the Senate has approved nearly 1400 treaties while voting to reject only 16 ).

${ }_{177}$ For example, President Taft declined to proceed with ratification of the 1911 Arbitration Treaties with France and Great Britain when the Senate attached important reservations. See RESTATEMENT, supra note $2, \S 303$, at reporter's note 3; see also Role of THE SENATE, supra note 2, at 125-26 (discussing examples of treaties a President declined to ratify after Senate consent).

${ }^{178}$ See U.S. ConST. art. II, § 1, cl. 8; see also Lobel, supra note 113, at 1114-15 (stating that the President does not ordinarily have power to violate treaty unilaterally).

17 See U.S. Const. art. I, § 8, cl. 1; see also Role of THE SENATE supra note 2 , at 136-39 (reporting various controversies regarding Congress' failure to pass promptly legislation necessary to implement treaties); L. HENKIN, supra note 151, at 161-62 (stating that the principle has not yet been resolved on whether Congress is obligated to pass legislation for implementing a treaty). 
role. Indeed, the roles are so interrelated that even self-executing agreements may be stymied by congressional action or inaction, including the override of a presidential veto of legislation that would supersede the treaty. ${ }^{180}$

Finally, the President seems to have the sole authority to terminate an international obligation of the United States, ${ }^{181}$ though the power to end a treaty is by no means the same as the power to modify one. The process of establishing an amended treaty is essentially the same as the process of creating a new treaty $a b$ initio, starting anew the sequence of shared and uncertain powers. ${ }^{182}$

\section{b. Interpreting Treaties}

Several players also figure in the interpretation phase. The President's interpretation is, in one sense, primary, for it is in the context of his near-plenary authority to conduct foreign relations that diplomacy will give international effect to an official United States interpretation. ${ }^{183}$ However, Congress, also "interprets" treaties. It assesses, as a domestic political and legal matter, what the document requires and what additional action should be taken within the constitutional scope of legislative powers to promote United States interests. ${ }^{184}$

180 See supra notes $150-58$ and accompanying text.

181 See L. HeNkin, supra note 151, at 167-71; Restatement, supra note 2, $\S 339$; see also Goldwater v. Carter, 617 F. 2 d 697 (D.D.C.), vacated and remanded, 444 U.S. 996 (1979) (a divided Supreme Court dismissed, on justiciability grounds, Senators' suit for review of President's decision to terminate treaty with Taiwan); N. Calvo-Goller \& M. Calvo, supra note 33, at 140-41 (surveying legislative and executive roles in precedents concerning treaty termination); Finkelstein, Star Wars Meets the ABM Treaty: The Treaty Termination Controversy, 10 N.C.J. INT'L L. \& Com. Reg. 701, 715 (1985) (the President is authorized to terminate a treaty without congressional action in the event of another nation's breach); Lobel, supra note 113, at 1121 (President has power to terminate, but not to violate, treaties); Comment, supra note 68, at 772-76 (analyzing methods for terminating the ABM Treaty).

${ }_{182}$ See Glennon, supra note 81, at 919 (President may not effectively call a new or amended treaty a mere interpretation of an existing treaty).

${ }_{183}$ See L. HenKin, supra note 151, at 167. The President will take into account a court's interpretation of a treaty, but in the conduct of international affairs, the President may adopt a different interpretation for dealing with other sovereigns. See id. at 416 n.128; RESTATEMENT, supra note $2, \S 326$, comment b.

184 See Johnson v. Browne, 205 U.S. 309, 317 (1907); United States v. Rauscher, 119 U.S. 407, 424 (1886). Both Rauscher and Browne refer to the "[c]ongressional construction of the purpose and meaning of extradition treaties" revealed in subsequent legislation as evidence of the legislative understanding of the law of the treaty. Browne, 205 U.S. at 317. As far back as the Washington Administration, the Executive asked the Senate's advice on interpreting or implementing a treaty. In 1791, France protested the application of certain American requirements to ships as inconsistent with the treaty of 1778. After considering the question, the Senate sided with the American Executive. See Role of THE Senate, supra note 2, at 35 . Similarly, in 1797 , the President referred to the Congress a question about implementation of the treaty with 
Courts also regularly interpret treaties in cases and controversies before them, establishing important principles of international and foreign relations law. ${ }^{185}$ The courts ordinarily demonstrate great deference to the Executive's interpretation of a treaty, attempting to avoid the possibility of embarrassing the President with a conflict. ${ }^{188}$ There are cases that present a very sharp conflict between executive and judicial interpretations, however, in which the courts have declined to give a treaty the sort of interpretation that the Executive desired. ${ }^{\mathbf{1 8 7}}$ Moreover,

Algiers. See id.; see also L. Henkin, supra note 151, at $416 \mathrm{n} .127$ ("In passing the Panama Canal Act of 1912, Congress apparently interpreted the Hay-Pauncefote Treaty as exempting American vessels engaged in coastwise trade from paying canal tolls, as did President Taft. Wilson later interpreted the Treaty differently and induced Congress to repeal the statutory exemption.").

More recently, it has been conceded that the President could not effectively switch to adoption and implementation of the "broad" interpretation of the ABM Treaty by a simple "flick of a pen." Rather, a President would have to obtain congressional assent for the funding of additional SDI activities. See 1985 SDI Hearings, supra note 59, at 397-98 (testimony of Assistant Secretary of Defense Richard Perle).

185 See, e.g., Japan Whaling Ass'n v. American Cetacean Soc'y, 478 U.S. 221, 230 (1986) ("IT]he courts have authority to construe treaties and executive agreements," as well as statutes, even when foreign affairs are implicated); Dames \& Moore v. Regan, 453 U.S. 654, 688 (1981) (partially sustaining presidential action settling claims arising from Iranian seizure of United States hostages); Banco Nacional de Cuba v. Sabbatino, 376 U.S. 398, 427-37 (1964) ("act of state" doctrine, precluding review of actions of a foreign sovereign in its own territory, is applicable even when expropriation of private sugar company allegedly violates international law); Filartiga v. Pena-Irala, 630 F.2d 876, 885-89 (2d Cir. 1980) (federal court may hear claim that a foreign government official, acting abroad under color of foreign authority, violated international law by using torture); see also L. HENKIN, supra note 151, at 165-67, 205-24 (discussing cases in which the courts have enforced treaty obligations).

American courts frequently interpret treaties when private rights of individuals are at stake. See, e.g., Kolovrat v. Oregon, 366 U.S. 187, 191 (1961) (treaty determines that Yugoslavian residents and citizens could inherit land in Oregon, despite restrictive state law); Asakura v. Seattle, 265 U.S. 332, 342-43 (1924) (treaty requiring equality for aliens overrides contrary state statute); Ware v. Hylton, 3 U.S. (3 Dall.) 198, 235 (1796) (peace treaty, establishing system for payment of private debts, supersedes contrary state law).

${ }_{186}$ See, e.g., Sumitomo Shoji Am., Inc. v. Avagliano, 457 U.S. 176, 184-85 (1982) ("Although not conclusive, the meaning attributed to treaty provisions by the Government agencies charged with their negotiation and enforcement is entitled to great weight."); Zschernig v. Miller, 389 U.S. 429, 432 (1968) (state escheat statute invalidated because it might intrude into foreign affairs); Kolovrat, 366 U.S. at 194-95 (court relied upon diplomatic notes and correspondence to establish meaning of 1881 treaty); Factor v. Laubenheimer, 290 U.S. 276, 295 (1933) (Court influenced by consistent State Department interpretation of extradition treaty); Foster v. Neilson, 27 U.S. (2 Pet.) 253, 307 (1829) ("It is scarcely possible, that the courts of either [nation in the boundary dispute] should refuse to abide by the measures adopted by its own government."); Coplin v. United States, 761 F.2d 688, 690-92 (Fed. Cir. 1985) (consistent executive interpretation of a treaty, even when expressed in diplomatic exchanges long after negotiation of the treaty, is entitled to great weight), aff d, 479 U.S. 27 (1986).

${ }^{187}$ See Perkins v. Elg, 307 U.S. 325, 335-42 (1939) (Court disagreed with Executive's current interpretation of a naturalization treaty with Sweden, favoring earlier 
situations do emerge in which a court speaks definitively to the treaty's meaning in the domestic law context, while the President is free to assert a different interpretation vis-a-vis other nations. ${ }^{188}$

Despite their own active role, courts have been reluctant to intervene in controversies between the two political branches of government. Often they cite the "political question" doctrine, ${ }^{189}$ or "standing"190 as

interpretation); Valentine v. United States ex rel. Neidecker, 299 U.S. 5, 10 (1936) (denying President any implied discretionary power under a treaty with France to extradite United States citizens); Johnson v. Browne, 205 U.S. 309, 320-21 (1907) (refusing to implement Executive's interpretation of an extradition statute with Great Britain); see also Restatement, supra note $2, \S 326$, reporters' note 2 (citing United States v. Decker, 600 F.2d 733 (9th Cir.), cert. denied, 444 U.S. 855 (1979); United States v. Enger, 472 F. Supp. 490 (D.N.J. 1978)).

${ }^{188}$ See President's Message to the Senate on the Soviet-United States Intermediate-Range Nuclear Force Treaty, 24 WeEkly Comp. Pres. Doc. 779, 780 (June 10, 1988) ("T The Supreme Court may well have the final judgment [regarding the interpretation of the INF Treaty], which would be binding on the President and Senate alike."); L. HeNKIN, supra note 151, at 167; RestatemeNT, supra note 2, § 326.

${ }_{189}$ Under the political question doctrine, courts have held a number of issues to be nonjusticiable, being reserved for resolution by the Legislative and Executive Branches. The leading case articulating the doctrine is Baker v. Carr, 369 U.S. 186 (1962), which establishes the guidelines for courts in applying the doctrine to the foreign affairs area. See id. at 211-12; see also Goldwater v. Carter, 444 U.S. 996 (1979) (vacated on other grounds) (four Justices vote to dismiss as political question a Senator's suit challenging the President's decision to terminate a treaty). But see Japan Whaling Ass'n, 478 U.S. at 229-30 (1986) (interpretation of treaty and statutes not political question, even though foreign relations involved); Henkin, Lexical Priority or "Political Question": A Response, 101 HaRv. L. REv. 524, 529 (1987) (expressing dislike for the political question doctrine as being "at odds with our commitment to constitutionalism and limited government"); Henkin, Is There a Political Question Doctrine?, 85 Yale L.J. 597, 600 (1976) (arguing that "there may be no doctrine requiring abstention from judicial review of 'political questions" ").

190 The "standing" requirement mandates that a lawsuit be brought by someone who has more than "the generalized interest of all citizens in constitutional governance." Schlesinger v. Reservists Comm. to Stop the War, 418 U.S. 208, 217 (1974). A plaintiff with standing is one whose stake in the controversy is within "the zone of interests to be protected or regulated by the statute or constitutional guarantee in question." Association of Data Processing Serv. Orgs., Inc. v. Camp, 397 U.S. 150, 153 (1970).

Even members of Congress do not have standing automatically to challenge executive actions assertedly beyond the authorization of a statute or the Constitution. Congressional standing exists only if the Executive's actions have effectively nullified a previous legislative vote or an opportunity to vote. See, e.g, Goldwater v. Carter, 617 F.2d 697,703 (D.C. Cir.) (Senators had standing to sue regarding presidential decision to terminate treaty with Taiwan because they had not been afforded an opportunity to vote), vacated on other grounds, 444 U.S. 996 (1979); Harrington v. Bush, 553 F.2d 190, 210 (D.C. Cir. 1977) (member of Congress lacks standing to challenge covert actions and secret funding of CIA); see also McGowan, Congressmen in Court: The New Plaintiffs, 15 GA. L. REv. 241, 266-67 (1981) (courts should hesitate to take suits in which members of Congress attempt to circumvent the political process); Note, Congressional Nuclear Freeze Proposals: Constitutionality and Enforcement, 23 HaRv. J. ON LEGIS. 483, 486-93 (1986) (summarizing federal courts' treatment of standing issues in various contexts); Note, The Justiciability of Congressional-Plaintiff Suits, 82 Colum. L. REv. 526, 542-44 (1982) (congressional lawsuits are particularly inappro- 
grounds barring the adjudication of issues touching on foreign affairs.

One very recent case, however, has demonstrated an extremely important role for the courts in treaty interpretation. In Rainbow Navigation, Inc. $v$. Department of the Navy, ${ }^{181}$ the plaintiff shipping company sought an injunction against the implementation of the Navy's reinterpretation of a 1986 United States-Iceland Treaty that regulated the carriage of military cargo between the two states. ${ }^{102}$

During the Senate's consideration of the Treaty, senior administration spokespersons (notably the Counselor of the Department of State, accompanied by the Commander of the Military Sealift Command) had testified that the Treaty would be implemented so as to protect the interests of the sole remaining United States-flag shipper active on that route. ${ }^{193}$ This assurance was cited in the Committee on Foreign Relations' report and on the floor of the Senate prior to Senate advice and consent to the agreement. ${ }^{194}$

Shortly after ratification of the Treaty, however, the Navy propounded a new interpretation of it. ${ }^{195}$ A new system for awarding transportation contracts for that route was developed, under which plaintiff Rainbow would likely be shut out, in favor of Icelandic competitors. ${ }^{198}$ When Rainbow sued, the Navy argued that the assurances

priate where a member of Congress seeks to challenge Executive Branch interpretation of a statute).

For discussions of congressional challenges to executive treaty interpretations, see Kennedy, supra note 5, at 873-77 (reviewing cases in which courts have denied Congress members standing to challenge treaty interpretations); see also Joint Hearings, supra note 1, at 414 (statement of Professor Laurence H. Tribe) (it is "highly problematic" to suppose that courts would grant standing to challenge the Executive's interpretation of the ABM Treaty).

The Senate has considered the option of enhancing the role of the courts in interpreting arms control treaties, but at least one spokesperson has concluded that "to bring the issue to resolution in the courts, to render the question 'justiciable,' would be complex and time consuming. It is therefore important . . . to avoid court action." Joint Hearings, supra note 1 , at 3 (statement of Sen. Biden).

191686 F. Supp. 354 (D.D.G. 1988); see also United States v. Stuart, 57 U.S.L.W. 4263, 4267 (1989) (asserting that nontextual sources such as "a treaty's ratification history and its subsequent operation" often assist the court to implement the parties' intent).

192 This was the third time that the parties had contested similar aspects of the controversy. For a synopsis of the dispute, see Rainbow Navigation, 686 F. Supp. at 354-55.

193 See id. at 358.

184 See id.

195 See id. at 356.

196 Under the original system, one competition was to be held each year, with the lowest bidder winning a contract to carry $65 \%$ of the Navy's cargo and the second lowest, from the other country, winning the right to carry 35\%. In 1987, Rainbow was the second lowest bidder, and took the $35 \%$ share. Under the Navy's proposed revision, there would be two competitions each year, one for $65 \%$ of the cargo and the other for $35 \%$ of the cargo. In each competition the lowest bidder would get the contract. Thus, 
offered to the Senate during the advice and consent period were not legally binding. The Navy contended: 1) that the Treaty was not intended to be self-executing, 2) that a private plaintiff such as Rainbow had no standing to sue, and 3) that previous government statements interpreting the Treaty in favor of Rainbow were merely "precatory." 187

In response to the Navy's arguments, Judge Harold Greene told the Justice Department litigator: "You are taking the same position that the State Department is taking on the [INF] Treaty, that whatever is said to the Senate doesn't mean anything."198 Judge Greene concluded that the government could not, on the one hand, represent to the Senate that the Treaty would be self-executing and would preserve Rainbow's presence on the Icelandic route and, on the other hand, assert in court that the Treaty created no justiciable issue in protecting Rainbow's right to compete fairly for contracts. ${ }^{189}$ The judge stated that the United States interest in good relations with an ally could not be pursued in violation "of the solemn representations made to the United States Senate in connection with the ratification of that treaty."200 $\mathrm{He}$ then granted Rainbow's motion for a preliminary injunction. ${ }^{201}$

As encouraging as the Rainbow Navigation case may be for recognizing the shared responsibilities of the Congress, the Judiciary, and the President, it is unlikely to be a harbinger of future increased judicial activism in the national security area. Only rarely will a court be presented with such egregious circumstances, and the Executive Branch will not ordinarily replicate the Navy's heavy-handed attempts at unilateral reinterpretation. Judge Greene's decision, however, also illus-

Rainbow might have been second lowest in each competition, and obtain neither contract. See id. at 360 .

197 See id. at 356-57 \& n.17.

198 The Treaty and Its Enemies, N.Y. Times, May 25, 1988, at A26, col. 2 (editorial). The government's position in Rainbow Navigation was even more extreme than the Sofaer Doctrine because the representations made to the Senate in 1986, in connection with the Iceland Treaty, were so definitive and so heavily relied upon by the Senate, that they would meet even the three strict criteria of the Sofaer Doctrine. See supra notes 83-84 and accompanying text. Yet the Justice Department denied that even these explicit assertions were binding. See 134 ConG. REc. S6774 (daily ed. May 26,1988 ) (statement of Senator Nunn) (noting that the Administration had disavowed the representations of the Navy and the State Department as "precatory" and "nonbinding").

199 See Rainbow Navigation, 686 F. Supp. at 358-59.

$200 \mathrm{Id}$. at 361.

201 See id. In a subsequent phase of the litigation, the Navy appeared to concede that it was bound by the representations it had made to the Senate during the ratification hearings. See Rainbow Navigation's Memorandum in Support of Its Motion For Summary Judgment, Rainbow Navigation, Inc. v. Department of the Navy, No. 880992 (HHG) (D.D.C. Nov. 15, 1988), at 2 n.1. 
trates the converse point, that courts' traditional deference to executive decisions is only a limited self-restraint, and that the customary judicial reluctance to intervene into sensitive matters of international and federal politics can be stretched too far.

3. The Senate has a variety of mechanisms for establishing its interpretation of a treaty.

The Senate has at its disposal a range of options for expressing qualified approval of a treaty and for influencing its implementation. Provisos labeled as amendments, reservations, understandings, and declarations vary in the degree to which the new legislative direction would alter or augment the obligations of the treaty. ${ }^{202}$ A new typology has identified three distinct classes of Senate expressions: Category I provisions do not involve any formal notice to the other party; Category II provisions are formally communicated to the other party as official United States government positions, but do not require acceptance or acknowledgement by the other party; Category III provisions require explicit agreement by the other party before the treaty can come into force. ${ }^{203}$

The Senate also has available a range of options regarding the appropriate legislative vehicle for expressing its view of a proffered treaty. The most explicit device for affecting interpretation is through the resolution of ratification. By means of provisions in this resolution, the Senate can directly instruct the Executive (and the other party) regarding the specific changes or restrictions that would be necessary before the Senate will provide its consent and allow the treaty to be made. Similarly, the resolution of ratification can serve as the mechanism for the Senate to declare plainly its "understanding" of the treaty or its future intentions regarding policy choices in a way that does not change the negotiated treaty but does overtly influence the surrounding legal or political milieu.

202 See supra note 176 . The Senate has affixed a variety of provisos to arms control treaties with different degrees of precision and explicitness. See Sofaer, $A B M T R e$ ports, supra note 77, at \$6674-75. With rare exceptions, all Senate provisos have been communicated to the other parties to treaties. See, e.g., id. at $\$ 6669$ (the general practice is to secure agreement of the other party to all such conditions by exchange of diplomatic notes); GENOCIDE CONVENTION REPORT, supra note 144, at 15 (noting that the 1976 Treaty of Friendship and Cooperation with Spain was the most recent deviation from practice of transmitting all Senate conditions to other party).

${ }^{203}$ See Restatement, supra note $2, \S 314$, reporters' note 1 . This typology was created by the Foreign Relations Committee in connection with the SALT II Treaty. See SFRC SALT II REPORT, supra note 35, at 28-35. It has become a standard part of the analysis of treaty reservations. 
The Senate also may express its qualified approval of a proposed treaty in a less prominent manner through other oral or written legislative tools. The treaty report from the Senate Foreign Relations Committee, for example, or statements made by leadership on the floor of the Senate may sometimes serve as expressions of the Senate's collective position. ${ }^{204}$

There are, however, situations in which the Senate's collective understanding or interpretation of the treaty has not been expressed at all and is therefore, especially difficult to discern. The most problematic is when there has been complete congressional silence on a particular matter. Sometimes the absence of expression on point may indicate that the Senate shared an understanding so basic that no elaboration was required. A particular matter may be thought to be so obvious or so well-accepted that it attracts no controversy and, in the tumult of the legislative process, inspires no explicit time and attention, yet subsequently emerges as a point in contention. ${ }^{203}$ At other times, silence signifies, instead, that the Senate simply had no considered view of the subject. $^{206}$

204 See, e.g., United States v. Stuart, 57 U.S.L.W. 4263, 4267 (1989) (using floor debate and President's transmittal documents to interpret the language of a treaty provision ratified by the Senate); Joint Hearings, supra note 1, at 82 (statement of Professor Louis Henkin) ("The same principle [that the President may make only a treaty that means what the Senate understood it to mean] governs when the Senate's understanding of a treaty provision is not expressed in a formal resolution, but is apparent from the Senate's deliberations leading to its expression of consent."); 1987 SFRC REPORT, supra note 4, at 40 ("Implicit understandings represent informal - but equally significant - conditions placed on the Senate's consent."); RESTATEMENT, supra note 2 , § 314, comment d; Biden \& Ritch, supra note 83, at 5 (noting that Senate intent need not be registered explicitly, but can with equal significance be implicit).

${ }^{205}$ See Joint Hearings, supra note 1, at 394 (joint statement of Abram Chayes and Antonia $H$. Chayes) (asserting that the very absence of Senate reservations or understandings about the meaning of the ABM Treaty indicates that everyone agreed upon the interpretation that emerged from the plain meaning of the text and had been sponsored by executive branch witnesses); INFT REPORT, supra note 8, at 93 (noting that implicit understandings represent Senate acquiescence with executive representations; Legislature's silence cannot change an Executive's explanations of the meaning of a treaty, but can reaffirm them); Biden \& Ritch, supra note 83, at 5 ("In truth, the Senate's understanding of a treaty is usually implicit - that is, registered via acceptance of Executive representations."). But see Joint Hearings, supra note 1, at 128 (statement of Abraham D. Sofaer, State Department Legal Advisor) (noting that it is dangerous to infer Senate approval of a witness's statement merely from acquiescence - the Senate must deal in generalities and often has no shared understanding of minor points).

${ }^{208}$ Often, the most important debates about a treaty occur away from committee meetings and from the Senate floor, taking place in Senators' offices where there is no record. See Joint Hearing, supra note 1, at 113 (statement of Senator Hollings). But even these off-the-record conversations may play a role in creating a Senate "understanding" of a treaty.

If the Senate gives no indication of its understanding of a treaty, it must be as- 
A comparison with the legislative process by which the Congress creates ordinary domestic law provides an illuminating analogy. ${ }^{207} \mathrm{Ob}$ viously the clearest method for the Congress to affect United States' jurisprudence is through the words of the statute. While even these expressions will be subject to varying interpretations, there is ordinarily little doubt that Congress intended to express something in the specific language of the statute. Other legislative tools of lesser dignity (or of greater subtlety), however, are also relevant in the law-making process, and thus influence subsequent interpretation. ${ }^{208}$ Courts frequently scrutinize the language of a committee report, a floor colloquy, or a debate, in order to ascertain the intentions of the legislative drafters. ${ }^{209}$ Moreover, occasionally when these overt expressions provide insufficient guidance, a court will attempt to adduce what the Congress "must have" intended by parsing the ordinary meaning of the language and the surrounding context and by inferring what the Congress would have said about a particular point had it taken the occasion to be explicit about all the underlying shared assumptions and understandings.

sumed that the Senate understood the treaty to mean what it would be understood to mean by reasonable people, reading the treaty in good faith, in accordance with the ordinary meaning of the words in their treaty context. See id. at 82 (statement of Professor Louis Henkin). But see Sofaer, ABMT Reports, supra note 77, at S6,669 (stating that one should not infer lightly that the Senate intended to implace unilateral conditions upon United States in consenting to a treaty).

${ }^{207}$ The State Department Legal Adviser and the Department of Justice Office of the Legal Counsel have asserted that there are two views concerning the role of legislative history in treaty interpretation. The first would consider the Senate's advice and consent record to be directly comparable to the Congress' record in statute-writing, according equivalent weight to both types of documents and analyzing them in a similar fashion. The other perspective would give significantly less weight to the Senate's work regarding a treaty than to the Congress' work regarding a statute, on the grounds that only the "drafter" of a law is entitled to extra deference, and the drafter of a statute is ordinarily the Congress, but the drafter of a treaty is the Executive. See Sofaer ABMT Reports, supra note 77, at S6673; OLC Memorandum, supra note 83, at 2; cf. Schwegmann Bros. v. Calvert Distillers Corp., 341 U.S. 384, 394-95 (1951) (concluding that a bill's legislative history, statements of the bill's sponsors are more important than those of its opponents).

${ }^{208}$ See, e.g., Emporium Capwell Co. v. Western Addition Community Org., 420 U.S. 50, 61 n.12 (1975) (referring to congressional reports to aid in construction of the National Labor Relations Act); Seacast Anti-Pollution League v. Costle, 572 F.2d 872, 877 \& n.7 (1st Cir.) (referring to legislative debate in interpreting the Administrative Procedure Act), cert. denied, 439 U.S. 824 (1978).

209 In regard to the interpretation of treaties, see United States v. Stuart, 57 U.S.L.W. 4263,4267 n. 7 (1989) ("[R]eliance on the Senate's preratification debates and reports [is not] improper."). For a discussion of the Court's use of legislative history more generally, see Johnson v. Transportation Agency, 480 U.S. 616, 629 n.7 (1987) (legislative inaction "may not always provide crystalline revelation" but "may be probative to varying degrees"); National Woodwork Mfg. Ass'n v. NLRB, 386 U.S. $612,639-40$ (1967) (cautioning against reliance upon views of legislative opponents who tend to overstate the reach of a disfavored provision). 
A particularly problematic treaty interpretation issue arises when the Senate derives its understanding of a particular clause in large measure from the Executive's initial interpretation, and the Senate then fails to articulate its acceptance of the Executive's view in the resolution of ratification or in any lesser legislative vehicle. Executive presentations regarding recently-concluded treaty negotiations ordinarily will be especially compelling to the Senate and likely to generate a shared, albeit perhaps inexplicit, understanding of what the text means. In these circumstances, persuasive executive testimony supportive of the Legislature's reading of the treaty's plain language influences the Senate's understanding yet passes unnoted.

The point here is not that the President or a successor should be "estopped" from later asserting a contrary interpretation. ${ }^{210}$ Rather, the President's representations, once accepted by the Senate, contribute to the development of a particular interpretation that, by law, has become affixed to the treaty text. It is the binding law, not an estoppel, that compels the outcome. Determining whether the Senate formed a coherent view of a particular clause, therefore, is the essential inquiry; the origin of any such interpretation is less important. ${ }^{211}$

Tacit forms of Senate understanding present substantial problems of proof. It is obviously easier to be confident about "what the Senate wanted" when the entire body has gone on record with an up-or-down vote on the question whether to include a particular provision in the resolution of ratification. Report language, floor colloquies, and the like, often are more ambiguous expressions of intent, and subsequent analysts may question the degree to which the Senate as a whole subscribed to the views of any few leaders. ${ }^{212}$

Despite these practical problems of establishing the existence and terms of an unwritten Senate understanding, once such an understanding has been shown to exist, there is no conceptual difficulty in assess-

210 But cf. OLC Memorandum, supra note 83, at 14 (arguing that "the President would, in effect, be estopped from taking a contrary position in his subsequent interpretation of the treaty" after the Senate relied upon a particular interpretation he had presented).

211 Executive statements, however, can be useful in providing evidence of what the Senate must have had in mind, based upon the materials before it at the relevant time. See Stuart, 57 U.S.L.W. at 4267-68 (referring to President's transmittal message to support an interpretation of the language of a treaty provision ratified by the Senate); infra text accompanying notes 249-53.

${ }_{212}$ See, e.g., SFRC SALT II REPORT, supra note 35, at 34 (citing the misunderstanding over the effect to ge given conditions attached to a treaty with Spain). But see Stuart, 57 U.S.L.W. at 4267 n.7 ("A treaty's negotiating history . . . would in fact be a worse indicator of a treaty's meaning [than preratification Senate materials] for that history is rarely a matter of public record available to the Senate when it decides to grant or withhold its consent."). 
ing its legal status. The Senate's understandings and conditions, however evidenced, are fully binding upon the President once the treaty is "made." The Senate's view of the treaty, whether explicit or implicit, is an integral part of the treaty, and the President cannot proceed to ratification on any other terms. ${ }^{213}$ The President may decline to ratify the treaty altogether, but he cannot selectively dispense with the Senate's input. ${ }^{214}$ In effect, the Senate gives its advice and consent to a particular treaty regime, not a blank check for any other type of arrangements that the President may desire. ${ }^{215}$

It is dangerous to construe congressional silence, and courts are often understandably reluctant to draw conclusions where there is scant

213 See Restatement, supra note $2, \S 314$. The President usually has included a verbatim recitation of any Senate reservation, declaration, or understanding, in the instrument of ratification. See id. comment b. As Professor Henkin has stated: "Of course, the President can only make the treaty to which the Senate has consented. He cannot make a treaty other than the one to which the Senate consented. . . . he cannot make a treaty with a meaning different from the one to which the Senate consented." Joint Hearings, supra note 1 , at 81 . But see id. at 130 (statement of Abraham D. Sofaer, State Department Legal Advisor) ("When [the Senate] gives its advice and consent to a treaty, it is to the treaty that was made, irrespective of the explanations it is provided.").

In Power Auth. of New York v. Federal Power Comm'n, 247 F.2d 538, 541 (D.C. Cir.), vacated and remanded with directions to dismiss as moot sub nom. American Pub. Power Ass'n v. Power Auth. of New York, 355 U.S. 64 (1957), the Second Circuit denied the status of "law of the land" to a Senate reservation to a treaty with Canada dividing the waters of the Niagara River. The reservation specified that the United States' share of the water would be allocated among domestic users only by an Act of Congress; the court ruled that this was not a proper reservation, since it was of domestic impact and importance only. See id. at 539. Therefore, the Second Court held, the reservation was not legitimately a part of the treaty, despite Canada's explicit acceptance of it, and United States waters could be allocated by actions of competent administrative agencies, as well as by Congress. This decision has been criticized, in a vigorous dissent as well as by others, as failing to recognize that the Senate, in considering a treaty, may condition its consent in almost any fashion, at least when there is a colorable connection to the content of the treaty. See id. at 548 (Bastian, J., dissenting); L. HeNkIN, supra note 151, at 134-36 \& n.28; Henkin, The Treaty Makers and the Law Makers: The Niagara Reservation, 56 Colum. L. Rev. 1151, 1176-79 (1956).

${ }^{214}$ But see New York Indians v. United States, 170 U.S. 1, 21-22 (1898). In this case the Senate had attached several provisions that would reduce the amount of money and land allocated to a group of tribes in a treaty. Most of these reservations were accepted by the Indians and included in the ratified treaty, but one was dropped somehow - the President did not include it in the proclamation, for reasons that do not appear in the Court's decision. See id. at 22-23. The Supreme Court gave effect to the treaty, and severed the unpublished reservation, denying the Senate enforcement of its condition. See id.

${ }^{215}$ Commentators generally agree that if the Senate explicitly insists upon an interpretation of a treaty and incorporates its position in the resolution of ratification, then it binds the President if the treaty is made. The difference of view, however, centers on the degree to which less formal, or unstated, Senate understandings - especially those that may have been generated tacitly by representations from executive branch spokespersons - are similarly entrenched. See Sofaer, ABMT Reports, supra note 77 , at $\mathbf{S 6 6 7 2 .}$ 
evidence of real congressional notice. ${ }^{216}$ But once the difficult questions of proof are overcome, there should be little debate about the legal status of congressional understandings of the treaty-making process. If Congress had a specific intention and a court can deduce from these secondary sources what that intent was, then that intent is binding and becomes part of the statute or treaty. The President cannot unilaterally ignore a congressional directive merely because it is obliquely or unartfully expressed. The President has a constitutional responsibility to enforce the entire law, including any portions of it that are revealed by indirect or tacit means. ${ }^{\mathbf{2 1 7}}$

\section{The critical moment for measuring the intentions of the Congress} and the Executive is the time at which the treaty is made.

The advice and consent period is the only time when the Senate has the authority to affect directly the content and meaning of a treaty. At this juncture the Senate can exercise the power to condition its consent and thereby entrench a particular interpretation as law. Once this moment has passed, however, and the treaty has been made, subsequent Senate expressions about its import or desirability no longer carry any special status. ${ }^{218}$ After ratification, the treaty that stands is the one that

${ }^{216}$ See, e.g., Johnson v. Transportation Agency, 480 U.S. 616, 629 n.7 (1987) (Court split on how to evaluate legislative inaction); Zuber v. Allen, 396 U.S. 168, 185 n.21 (1969) (rejecting argument that congressional inaction constituted endorsement of Department of Agriculture's interpretation of statute); Helvering v. Hallock, 309 U.S. $106,119-22$ (1940) (refusing to consider congressional inaction an endorsement of prior judicial interpretation). But see Bob Jones Univ. v. United States, 461 U.S. 574, 599 (1983) (congressional inaction constitutes endorsement of Internal Revenue Service's interpretation of tax exemption provisions); Dames \& Moore v. Regan, 453 U.S. 654, 678-799 (1981) (inference that legislative inaction reflects acquiescence in executive actions is even stronger in foreign affairs sector). See generally Easterbrook, Legal Interpretation and the Power of the Judiciary, 7 HARv. J.L. \& PUB. POL'y 87, 93-94 (1984) (concept of legislative intent is amorphous and judges have limited power to insert new meaning into ambiguous statutory language); Eskridge, Interpreting Legislative Inaction, 87 MICH. L. REV. 67, 70 (1988) (arguing that the legislative inaction decisions are "about presumed, rather than actual, legislative intent").

217 Of course, not every committee report or floor debate reflects legislative consensus or purports to be binding. Sometimes individuals or groups declare their own intentions or understandings, but there is no evidence that the legislature as a whole adopted their position as a part of the law. Furthermore, sometimes a committee report declares merely what should be done, as opposed to what shall be done. But these are problems of proof - albeit often insurmountable problems for the proponents of an effort to rely upon an incomplete legislative history as an expression of law. The legal principle, on the other hand, remains relatively straightforward: where there is an ascertainable congressional intent, it is binding, even if it is expressed via committee or floor action rather than in the text of a statute.

218 See RESTATEMENT, supra note 2 , § 326, reporters' note 1; see also Fourteen Diamond Rings v. United States, 183 U.S. 176, 180 (1901) ("The meaning of the treaty cannot be controlled by subsequent explanations of some of those who may have 
was made, and a subsequent congressional attempt (other than through the passage of new law) to state authoritatively what the document does or should mean is too late to be binding. ${ }^{218}$

By the same token, the President's ability to implant a binding understanding is similarly limited to the phase of treaty consideration prior to ratification. Once the Senate has given its advice and conditional consent, the President must either accept the Senate's terms or decline to make the treaty. A President cannot ignore Senate conditions or unilaterally alter them. A fortiori, if the President presents the treaty in one way, and the Senate accepts that understanding, it would render the advice and consent process futile if the Executive were later free to depart from those earlier representations.

These principles do not require that the meaning of a treaty must be permanently frozen until a subsequent law-making activity fulfilling the requirements of bicameralism and presentment explicitly supersedes it. ${ }^{220}$ Indeed, judicial interpretation of a treaty or statute, or of the Con-

voted to ratify it."); Jones v. Meehan, 175 U.S. 1, 32 (1899) ("The construction of treaties is the peculiar province of the judiciary; and, except in cases purely political, Congress has no constitutional power to settle the rights under a treaty, or to affect titles already granted by the treaty itself.").

218 Again, the comparison to statutes is revealing. Congress has wide powers to affect the meaning of pending legislation through eclectic means (via committee reports, floor debates, etc.), but these powers wane once the bill becomes law; a subsequent Congress ordinarily can change the original meaning of a law only through another enactment. See, e.g., Weinberger v. Rossi, 456 U.S. 25, 35 (1982) (noting that postenactment statements by congressional committees "are not entitled to much weight" in interpreting the intent of statute); Consumer Prod. Safety Comm'n v. GTE Sylvania, Inc., 447 U.S. 102, 118 (1980) (asserting that the intent of the enacting Congress, not a later Congress, is controlling); Oscar Mayer \& Co. v. Evans, 441 U.S. 750, 758 (1979) (stating that a Senate report written eleven years after passage of legislation does not control judicial interpretation); United Air Lines, Inc. v. McMann, 434 U.S. 192, 200 n.7 (1977) (intent of Congress after enacting Congress not controlling); International Bhd. of Teamsters v. United States, 431 U.S. 324, 354 n.39 (1977) (asserting that the intent of the enacting Congress, not a later Congress, is controlling). But see Seatrain Shipbuilding Corp. v. Shell Oil Co., 444 U.S. 572, 596 (1980) (arguing that the views of a subsequent Congress are entitled to significant weight, especially when the intent of the enacting Congress is obscure); Easterbrook, supra note 216, at 91 (rules of statutory construction are a total jumble; for every supposed rule there is a contrary rule).

${ }^{220}$ See Sofaer, ABMT Reports, supra note 77, at $\$ 6,672$. Judge Sofaer describes an illuminating example of treaty reinterpretation accomplished by joint action of the Executive and the Legislature concerning the 1901 Hay-Pauncefote Treaty with Great Britain. Treaty to Facilitate the Construction of a Ship Canal, Nov. 18, 1901, United States-United Kingdom, 32 Stat. 1903, T.S. No. 401. In 1911, President Taft had interpreted the Treaty to mean that certain American ships were exempt from paying Panama Canal tolls, and Congress had legislated its agreement, in the Panama Canal Act of 1912, Pub. L. No. 62-337, 37 Stat. 560, 562 (1912). President Wilson, however, considered that interpretation to be "in plain contravention of the Treaty," and he asked Congress to rescind it, which Congress did by statute in 1914. Act of June 15, 1914, Pub. L. No. 63-113, 38 Stat. 385, 386 (1914); 51 CoNG. Rec. 8944, 8944-45 (1914). 
stitution itself, may be adapted to evolving circumstances, importing new meanings to old law and legislative history. ${ }^{221}$ But the process of accretion and erosion has limits - there is a difference between a permissive reinterpretation of a law and the creation of a new law. The text and surrounding materials of a treaty can be stretched only so far. ${ }^{222}$

On some occasions, the Senate and the President may not have formulated any particular interpretation or understanding about a specific clause at the time the treaty was made. Under these circumstances, no legal standard is initially created, leaving greater scope for subsequent executive or judicial interstitial law-making. But where the Senate did impose conditions upon its consent, and the President ratified the treaty subject to those understandings, the entrenched treaty law should not be so malleable. ${ }^{223}$

\section{Strict mutuality of treaty obligations is unlikely and legally unnecessary.}

While it may seem anomalous to include a discussion of treaty mutuality under a heading of constitutional considerations, it is not uncommon for protagonists in the treaty interpretation debate implicitly to assume that the principle of mutuality has almost constitutional ramifications. It is sometimes asserted that strict "mutuality of obligations" is an inherent and vital aspect of international agreements, and that any asymmetry in parties' commitments is somehow indicative of impropriety or folly. ${ }^{224}$ In fact, however, this mirror-imaging of treaties may be

221 It has been argued that the Supreme Court is more willing to overrule precedents (that is, to change its own interpretation of the law) in constitutional cases than in statutory cases. The difference is attributed to the Court's realization that it is very difficult for the political process to reverse the Judiciary on constitutional matters (by amending the Constitution), but relatively easy for the Congress and President to take effective action to assert a different statutory preference (by passing new legislation). See Eskridge, Overruling Statutory Precedents, 76 Gro. L.J. 1361, 1362 (1988). Treaties might be an even more extreme case because the participation of another sovereign adds an element even more removed from the United States political process. One might expect, therefore, even greater willingness of the judiciary to play an active, revisionist role.

${ }^{222}$ See Gross, supra note 75, at 46-52 (disputes about treaty implementation should be resolved by renegotiation, not reinterpretation).

${ }^{223}$ Cf. Chevron U.S.A., Inc. v. Natural Resources Defense Council, 467 U.S. 837, 863-64 (1984) (finding that where a statute and legislative history are ambiguous, EPA has authority to interpret the statute flexibly, including the power to change its interpretation by implementing new regulations from time to time).

224 See, e.g., Joint Hearings, supra note 1, at 49 (statement of Senator Specter) ("The basic treaty principle, as a matter of contract, is that there has to be mutuality. So, if the Soviet Union is not bound, is the United States bound?"); id. at 124 (statement of Abraham D. Sofaer, State Department Legal Advisor) ("[T]he Senate is as 
the exception, rather than the rule, and it is, in any case, wholly unnecessary as a matter of law.

Reciprocity 225 and "equal security"226 may be important political aspects of most arms control accords, but there are several situations in which a desirable treaty regime may impose asymmetrical obligations upon its parties. First, the negotiated terms of the treaty itself may create differing requirements for the participants. Even parties that have equal bargaining power may, as in the case of the SALT I Interim Agreement, agree to retain stockpiles of armaments that are unequal in numbers but otherwise equivalent in power. ${ }^{227} \mathrm{Or}$, they may find it expedient to agree on unequal reductions in arms in order to reach lower, equal ceilings. ${ }^{228}$

responsible as the President for making sure that the contracts made in behalf of the United States are mutually enforceable and do not create unilateral duties."); President's Message to the Senate on the Soviet-United States Intermediate-Range Nuclear Force Treaty, supra note 188, at 780 ("As a practical matter, the Senate condition [to the INF Treaty] only can work against the interests of the United States by creating situations in which a treaty has one meaning under international law and another under domestic law. Unilateral restrictions on the United States should be avoided, especially in a treaty affecting vital national security interests.").

Oddly, in the debate regarding the Biden Condition to the resolution of ratification of the INF Treaty, see supra notes 90-112 and accompanying text, the Executive Branch's concern over possible non-mutuality of treaty obligations seemed self-defeating. In fact, the only way that non-mutuality could occur in this context was if the Executive Branch had not fully and accurately apprised the Senate of the complete picture of the treaty obligations that had been negotiated between the delegations of the United States and the Soviet Union. As long as the Executive presented a comprehensive disclosure of the obligations that the United States was entering, then the Senate and the Executive would share a "common understanding." The Senate's fear partially concerned this precise point - that the Executive might not have been punctilious in disclosure, such that the Soviets might have other understandings or interpretations not provided to the Senate. In a sense, the Reagan Administration was arguing: "Don't bind us to what we've told the Senate, because it's possible that we've cut a somewhat different deal with the Soviet Union, and although we may not tell you about it now, it's important that both the United States and the Soviet Union be bound only by the international deal."

${ }^{228}$ See Comm. on InT'l Arms Control and Security Affairs, Ass'n of the Bar of The City of New York, Achineving Effective Arms Control: RecomMENDATIONS, BACKGROUND, AND ANALYSIS 35-36 (1985); see also RESTATEMENT, supra note 2, pt. III, at 147 (discussing the resemblance between contract law and international law).

${ }^{226}$ See SALT II Treaty, supra note 51, 18 I.L.M. 1155 (preamble). One commentator has described the language "equal security," which the Soviets have frequently insisted be included in the preamble to arms control agreements, as "an Aesopian phrase which would entitle them to a force equal to the sum of all the other nuclear forces in the world." Rostow, Why Is It So Hard to Negotiate with the Russians?, 6 PACE L. REv. 1, 17 (1985).

${ }^{227}$ For example, in the Interim Agreement, supra note 13, the United States and the Soviet Union agreed, as a temporary measure, to "freeze" their respective stockpiles of ICBMs and SLBMs at levels which were quantitatively unequal, but qualitatively equivalent. See supra notes 32-33 and accompanying text.

${ }^{228}$ For example, the SALT II Treaty, supra note 51, required the Soviet Union 
Second, there may be ambiguities or gaps in the treaty's coverage that allow the parties lawfully to move unilaterally in different directions. Because parties will retain control over their own military forces, and will implement the treaty in their own interest, they may take different actions that are associated with the items covered by the treaty. ${ }^{229}$ For example, the INF Treaty eliminates intermediate-range and shorter-range missiles, but leaves each party free to retain aircraft and very-short- range missiles without restriction. ${ }^{230}$ The parties may well react differently to these opportunities, in ways that nonetheless have implications for the security relationship contemplated by the Treaty.

Third, the domestic processes leading to treaty ratification may impose different obligations on the various parties. Some Senate declarations or understandings, for example, are of internal legal effect only, but they may, nonetheless, create new law for this country governing areas close to the treaty and having an international importance. ${ }^{231}$ Subsequent enactments also can create dissimilar arrangements among treaty powers.

Finally, there is a sense in which treaties are inherently "nonmutual." An international obligation, even one that on its face is purely symmetrical, will take its place inside the network of domestic law that characterizes each of its parties. Since legal systems vary so much, and the domestic legal environments into which the treaty will move are so dissimilar, the effects of the treaty also may differ in noteworthy

to undertake greater reductions than the United States in order to reach a common level of weaponry. See J. Goldblatr, ARMs Control Agreements 35 (1983). Similarly, the INF Treaty, supra note 8 , required the Soviet Union to dismantle more weapons than the United States, to reduce both sides to zero within the covered categories. See Linden, INF Faces a Final Hurdle, TIME, Feb. 8, 1988, at 31.

${ }^{228}$ For example, the Interim Agreement, supra note 13, and the SALT II Treaty, supra note 51, both reserved for the United States and the Soviet Union considerable "freedom to mix," which is the ability of each country to configure its residual nuclear forces in any way each nation saw fit. The two countries have exercised this freedom asymmetrically, with the Soviet Union putting a far larger fraction of its strategic forces into ICBMs and the United States spreading more of its weaponry among SLBMs and aircraft. See, e.g., Stockholm International Peace Research Institute, 1987 SIPRI YEARBOOK 4-24 (1987) (detailing divergent American and Soviet force postures).

${ }^{230}$ The Treaty eliminates all ground-based missiles capable of ranges between approximately 300 and 3500 miles, but does not apply to shorter-range systems, to seabased systems or to aircraft. See INF Treaty, supra note 8, at 1459 .

${ }^{291}$ If they are not communicated to the other party, Senate understandings or interpretations formulated during the advice and consent period are not legally binding upon the other party. They may have some probative value in interpreting the treaty, as indicia of the parties' contemporaneous intent, but their main function will be to create domestic law for the country generating them. See Sofaer, ABMT Reports, supra note 77 , at $\mathbf{S} 6670$. 
ways. $^{232}$

The domestic legal environments in which a treaty between the United States and the Soviet Union is implemented, for example, are starkly different. In the United States, the Bill of Rights, environmental protection legislation, laws regarding occupational health and safety, and the Internal Revenue Code, for example, constitute major, unique parts of the legal milieu in which the treaty is implemented. The subtle influence of domestic jurisprudence may align government powers and privileges in the United States in ways that are inapplicable to the Soviet Union, because of the very different constraints of its own system.

For example, the INF treaty affords the parties identical rights to destroy excess missiles by explosive means. ${ }^{233}$ However, the environmental protection laws may effectively forbid such destruction inside the United States, creating an asymmetry where the negotiators contemplated none. Similarly, constitutional restrictions on government searches and seizures might restrict the ability to conduct on-site inspections inside the United States, even if no parallel Soviet limitations exist. ${ }^{234}$

These inherently non-mutual factors mean that whenever a United States-Soviet Union arms control treaty is concluded, it is quickly transformed into two treaties, one governing the United States and a similar, but subtly different one restricting the Soviet Union. ${ }^{235}$ The fundamental obligations under international law remain symmetric, but the governments' respective abilities to take advantage of the permissions and to implement the restrictions, under their differing domestic law, indicate that the interpretations of the treaty will quickly diverge. ${ }^{236}$

232 See Glennon, supra note 81, at 914 (disparity between domestic and international obligations of a treaty is "a contingency inherent in the nature of the relationship between the two legal systems"); see also 1987 SFRC REPORT, supra note 4, at 60 (in discussing the problem of disparity, the report states that "the problem . . . inheres in the very existence of two separate but interactive systems").

${ }^{233}$ See INF Treaty, supra note 8, Protocol on Procedures Governing the Elimination of The Missile Systems Subject to the Treaty Between the United States and the USSR on the Elimination of Their Intermediate-Range and Shorter-Range Missiles part II, at 1469-74.

${ }_{234}$ See Koplow, Arms Control Inspection: Constitutional Restrictions on Treaty Verification in the United States, 63 N.Y.U. L. REv. 229, 290-91 (1988).

23s See INFT REPORT, supra note 8, at 103 ("It is a truism that the Executive has different obligations under domestic and international law, and therefore it is possible to hypothesize situations in which those obligations could conflict. However, in practice this has not proven to be a serious problem and there is no basis for the Administration's assertion that the [Biden] Condition 'would substantially increase this risk." ").

${ }^{298}$ It might be even more appropriate to conceptualize a treaty as generating as many as three overlapping but independent bodies of law: one concerning solely the 
It may be poor politics, or poor international strategy, for the United States to tolerate any gross disjunction between the treaty-asdomestic-law that constrains the United States and the (corollary, but presumably less restrictive) treaty-as-domestic-law that constrains the Soviet Union. ${ }^{237}$ Such a disparity, however, may be an inevitable byproduct of the separate sovereignty of the two parties and the disparate domestic legal systems that inform and give meaning to the treaty as local law. As long as the United States Constitution retains its structure of a separation of powers and a two-step process for treaty-making, the Legislature will retain the opportunity to put its own stamp of approval and understanding upon any document negotiated by the Executive. Opportunities will always exist for subtle slippage between the moment of negotiation and the moment of ratification, thus shattering the illusion of mutuality. ${ }^{238}$

international obligations of the parties, as they have assumed responsibilities toward each other that, in theory, could be decisively ruled upon by an international tribunal; a second concerning the domestic import of the treaty as it is received inside the United States' legal structure; a third concerning the treaty's effect as domestic law of the Soviet Union.

The United States will have a political interest in the domestic implementation of the treaty inside the Soviet Union, and vice versa. But neither will have a lawful claim to intervene in the other's internal processes, and each will be free to alter its own domestic law as it sees fit, so long as the international obligations are met. One nation's domestic arrangements may well constrain it more than the other party's law constrains its actions, but this anomaly is a matter of domestic, not international, law and it is by no means necessarily indicative of any failure of the treaty regime. See RESTATEMENT, supra note $2, \S 301$, comment c, reporters' note 3 .

${ }^{237}$ See, e.g., Joint Hearings, supra note 1, at 372 (statement of Abraham D. Sofaer, State Department Legal Advisor) (if the Senate imposed greater restrictions upon the United States than the treaty itself imposed upon the other party, then the United States "would be put at a significant disadvantage"). Ironically, however, in the case of the ABM Treaty, it is the Executive Branch, not the Legislature that is attempting to create a double standard. That is, the Executive Branch posture - stating that the broad, permissive interpretation is "legally correct," but also declaring that the United States will voluntarily confine itself to the older, more restrictive interpretation, as a matter of policy - would give the Soviet Union license to proceed further with ABM systems development than the United States will.

238 The best way to minimize this area of discontinuity would be for the Executive to be accurate and effective in conveying to the Senate a full appreciation of the contents and implications of the negotiated treaty. If the text is comprehensively explained, the Senate's understanding of it should approximate the Executive's own understanding, and they will both be approving substantially identical notions of what the treaty entails. Conversely, if the Executive is incomplete in its presentation of the treaty that it has negotiated, then there is a greater danger that the document, as the Senate understands and consents to it, will be somewhat different - perhaps more restrictive than what the Executive contemplated and negotiated. See Biden and Ritch, supra note 83 , at 6 .

Another red herring associated with the argument for mutuality is the claim that if the ratification process is considered an effective device for making law, then treaty negotiators would suddenly be forced to assume a major new burden of monitoring each other's legislative process. In fact, the United States and the Soviet Union already mon- 


\section{APPLying the LAW to the FaCts}

This portion of the Article seeks to construct a workable model of treaty interpretation by applying the general framework of principles established above to various possible sets of facts. Four hypothetical situations involving executive reinterpretation of a treaty are presented in Part A. In light of the conclusions supported by the analysis of these hypotheticals in Part B, I present an alternative to the Sofaer Doctrine in Part C. This alternative provides a coherent model of treaty interpretation based on eight interdependent tests that indicate when an interpretation has become entrenched into law. This model is characterized by the necessary fidelity to both international and constitutional imperatives, and the requisite flexibility to meet the exigencies of international negotiations.

\section{A. Scenarios of Treaty Interpretation}

\section{Knowing Misrepresentation}

In the first scenario, the Executive presents a treaty to the Senate, and deliberately conceals (or misrepresents) one of the terms. Most plausibly, this would be a relatively confined, perhaps obscure, issue that escapes detailed legislative attention when the Executive Branch assures the Congress that the point is unproblematic because it has been resolved in a satisfactory manner in the text and classified negotiating history. Later, however, the matter emerges out of the shadows,

itor each other's domestic ratification processes with great interest, just as they study with care all other developments related to their security concerns. See Joint Hearings, supra note 1, at 59-60 (statement of Senator Nunn) (Soviets sent observer to the 1972 Senate Armed Services Committee hearings on the ABM Treaty ratification). Nevertheless, the Legal Adviser has asserted that if a state's domestic advice and consent phase has international significance, United States diplomats would be required to devote considerable additional energy to scrutinizing a treaty's progress through other nations' domestic ratification processes. Moreover, they would have to ensure that all other parties were being equally attentive in studying the events leading to ratification in the United States. See Sofaer, ABMT Reports, supra note 77, at S6671.

The short answer to this illusion is a return to the previous observation of the distinction between the international and the domestic law-making aspects of a treaty. See supra text accompanying note 231 . That is, one country's advice and consent process cannot impose legal burdens upon the other state - only a mutually-accepted negotiated agreement can accomplish that. So neither side has an obligation to monitor the other's domestic processes. On the other hand, each country will ordinarily have a profound political interest in discovering what its negotiating partner is contemplating, especially in areas that are intimately connected with an arms control treaty. So while the advice and consent process does make domestic law for the United States, if it varies from the obligations assumed by both parties in the negotiations, it is law that is binding only upon this country. The Soviet Union will, in all likelihood, continue to monitor these developments closely, but will not be constrained by them. 
and the Executive (whether the same or a successor President) advises the Congress that the constraints actually agreed to by the other party were not identical to the constraints that the Congress thought it was approving. ${ }^{239}$

\section{Subsequent Alteration}

The second case arises when the President who negotiated the treaty does a fair and accurate job of advising the Senate of its contents, but a subsequent President attempts to twist the treaty to a different meaning, by unilaterally "reinterpreting" it. In the "pure" case, the Executive would assert an unconditional ability to reinterpret the treaty on his own authority, at any time and to any extent. In a more complex variant, the Executive might argue that selected legal standards said to govern reinterpretation had been met, and that the factual record was sufficiently ambiguous to render the proffered change legitimate.

\section{3. "Glear Unclarity"}

In the third scenario, the negotiating parties agree that the treaty does not quite nail down a resolution of some possible future issue. They recognize that there is a gap or ambiguity in the treaty's coverage, but they are nonetheless willing to make the agreement promptly, and deal with the outstanding issue at a later time. There are many reasons why the text might be incomplete or unclear in this way, including either parties' desire to preserve some future flexibility, the parties' inability to fashion a mutually acceptable resolution for every point, and the hope that the lingering issues will not arise in acute form. A variant of this scenario might occur if there were a comparable type of ambiguity internal to the United States - an acknowledged inconsistency or unclarity between the respective executive and legislative understandings, intentions, or preferences regarding the treaty, which the participants acknowledge, yet agree to defer resolving.

\section{Unforeseen ambiguity}

The fourth scenario is similar to the third, except that the parties are not, at the time of making the treaty, fully conscious of the omission, imperfection, or ambiguity buried in their joint treaty text. Per-

${ }^{239}$ Compare this scenario with Joint Hearings, supra note 1, at 36 (statement of Senator Biden), describing a similar scenario of the Executive misleading the Senate to obtain advice and consent to a treaty when the secret negotiating record contains provisions that are substantially different from those disclosed in testimony. 
haps they are trying to work very quickly, perhaps they are insufficiently prescient about future technological developments, or perhaps they simply have not been able to imagine and anticipate each possible loophole and filigree.

\section{B. Analysis}

The general framework of principles derived from international and constitutional law established in Part II will help illuminate the obligations of the parties in these various scenarios.

\section{International Law}

The international law constraints on the other party (for example, the Soviet Union) will be only those established by the international agreement itself. ${ }^{240}$ In Scenarios 1 and 2, this means that the Soviets will be bound by the agreements in the treaty - nothing more (even if the United States accepts additional obligations as a matter of internal law), and nothing less (even if the United States drops its additional, self-imposed internal restrictions). The internal United States misrepresentations or contortions of Scenarios 1 and 2 are thus irrelevant to the text as binding upon the Soviet Union.

In Scenarios 3 and 4 there is no constraint on the Soviet Union regarding the omitted points - the lacuna is not filled until the parties concur on additional limitations. The United States may not like the measures that the Soviet Union exercises with its freedom, but has no valid objection in law. ${ }^{241}$

Regarding the United States' international obligations, international law mandates continuing observance of the treaty's terms by the United States, as well as by the Soviet Union, in all four scenarios. Whether the Executive has misled the Congress (as in Case 1) or is attempting to wrest the interpretation away from the agreed language (as in Case 2), the treaty nonetheless stands as binding under international law. ${ }^{242}$ Again, the United States is no more bound than is the

${ }^{240}$ See supra notes $118-24$ and accompanying text.

241 In the context of the ABM Treaty, one observer has stated: "The treaty does not define terms such as 'development' and 'component' that mark crucial dividing lines between activities that are consistent with the treaty and activities that are not. Thus, the Soviet signature on the ABM Treaty does not denote a given interpretation of these terms." Voas, supra note 76, at 1.

212 An argument could be made under these circumstances that the Senate's advice and consent was void because it was not "informed consent," and therefore, there should be no treaty at all, under either domestic or international law. But unless the other party was aware of (and participating in) the constitutional infirmity, the United 
Soviet Union in Scenarios 3 and 4: if the treaty did not establish a legal regime on point, then the international obligations of the parties do not extend to issues that might have been covered had the parties considered them.

\section{Constitutional Law}

The internal obligations of the United States, however, are more complex. ${ }^{243}$ For domestic law purposes, the treaty in Scenario 1 must include the Executive's misrepresentations. This is the version of the treaty to which the Senate has consented, and which has become the law of the land.

If the two sets of obligations are consistent - that is, if the misrepresentations establish constraints that are more restrictive than those of the international obligations, so that the United States could manage to comply with both sets of limitations - then that combination of restrictions is what the President has the responsibility to execute faithfully. The United States could, as a matter of domestic law, relax the additional restrictions, but until a domestic lawmaking step is taken, both sets of laws must be enforced.

This Scenario could give rise to a troubling possibility. If the United States acted on its view that the international law interpretation was less stringent than its domestic law version by modifying its domestic law to loosen the restriction, the Soviet Union might then attempt to argue that the more restrictive interpretation actually was not a "mistake." Rather, the Soviets could assert that the President's original presentations to the Senate were the more accurate reflection of the treaty text and negotiations. Accordingly, the same problem that marks Scenario 2 may arise: the Soviets could contend that it was the later executive statements that were the distortions. In either case the Soviets might urge that the more restrictive understanding of the treaty was required by international law, not merely by domestic United States law. If the United States persisted in its view and modified its domestic law to reflect the less stringent interpretation, the controversy could be presented as a straight international law question of treaty interpretation, in principle suitable for international adjudication.

A different sort of difficulty arises if the two sets of obligations in Scenario 1 are not consistent. For example, the Executive's misrepresentation may have created a domestic law that is less restrictive than

States would remain internationally bound. See Joint Hearings, supra note 1, at 550 (letter from Professor Richard B. Bilder).

24s See supra notes $150-223$ and accompanying text. 
the international law obligations under the treaty. Nevertheless, if the lax domestic law is merely permissive, then the President may have the option to refrain from taking advantage of it, and thereby keep the United States in conformity with the tighter international obligations of the treaty. If the domestic law is mandatory, however, then until that domestic law is changed, the President will be obligated to effectuate the domestic law, bringing the United States into breach of its international obligations and making it vulnerable to the remedies favoring the Soviet Union.

In Scenario 2, the domestic law of the United States will be the original treaty, the one that was made with Senate advice and consent. The "pure" or extreme reinterpretation case, where the Executive asserts an unconditional authority to change the treaty interpretation unilaterally, appears to be impermissible on its face; the President can no more single-handedly change this aspect of United States jurisprudence than he can change any other domestic law. If the treaty has become integrated into the law of the land, and the Senate's original interpretation is sufficiently entrenched, then unilateral reinterpretation cannot be effective.

If the facts of the controversy place it into the more complex variant of Scenario 2, however, the President may argue that there is no interpretation so well established as to be immutable, thus justifying a reinterpretation. The next section of this Article presents circumstances that justify or limit reinterpretations, and describes the factors that must be balanced to determine whether the attempt at subsequent alteration should be effectuated.

Where there is a known or latent ambiguity in the text at the time the treaty is made, as in Scenarios 3 and 4, neither domestic nor international law will bind the United States. If the President has not represented to the Senate that there is an agreement on a particular point, and if the Senate has not registered any relevant understanding, then the ratification, in effect, gives the President (as well as the Soviet Union) a blank check. This leeway has been granted knowingly in a Case 3 situation and unknowingly under Case 4. Any subsequent presidential assertions will not be "reinterpretations" - they will be "interpretations" - and, accordingly, they will not conflict with any previously expressed will of the Congress. Of course, the Congress may disagree with the import of the initial presidential interpretation and may act politically and legally to attempt to defeat it, but this will be strictly a contest of domestic lawmaking, within familiar parameters. 


\section{G. When Is a Treaty Interpretation "Entrenched" into Law?}

This section of the Article attempts to define "entrenchment" by proposing an eight-pronged test to describe the circumstances under which an interpretation of a treaty should be considered legally binding. Taken individually, no one of the eight factors ordinarily could be dispositive, but all of them may have a bearing in deciding a particular case. Whenever the Executive proffers a treaty reinterpretation, its legitimacy and its ability to oust a prior interpretation of the treaty can be analyzed under these eight conditions. The task of the analyst, therefore, is to collect the relevant data and balance these eight elements against each other.

As discussed in Part $\mathrm{I}$, most current assertions about reinterpretation powers are seriously wanting. At one extreme is the notion that the President may unilaterally reinterpret international obligations almost at will, regardless of previous assurances and understandings provided to the Senate. ${ }^{244}$ Surely this cannot be correct, for the process of Senate advice and consent must be constitutionally meaningful and cannot be circumvented willy-nilly by wholesale executive manipulations. Equally extreme would be a view that too drastically restricts the Executive's ability to deal with situations of ambiguity and incompleteness in the treaty text and negotiating record. The Executive must retain some flexibility, not being forever foreclosed by inadvertent statements or the Senate's partial or inchoate impressions.

The most recently asserted Executive Branch standard governing reinterpretations, the Sofaer Doctrine, is also unacceptable. ${ }^{245}$ No persuasive legal authority has been cited to support it. The "Doctrine" seems to have been fashioned on the spur of the moment to meet the needs of a particular controversy, with no particular basis in law. ${ }^{246}$ As a jurisprudential tool, it is incomplete, focusing on only three factors. Moreover, the nature of those tests calls into question the Doctrine's objectivity; the tests it proposes for entrenching a binding Senate understanding are so stiff that they may only rarely be met. ${ }^{247}$

244 See supra note 82 and accompanying text.

${ }^{245}$ See supra notes 83-85 (discussing the view that executive representation can be relied upon only if it has been "generally understood," "clearly intended" and "relied upon" by the Senate during the ratification process). See generally OLC Memorandum, supra note 83 .

${ }_{246}$ See INFT REPORT, supra note 8, at 90-91 (maintaining that the Sofaer Doctrine, though alleged to have been grounded in "settled principles," in fact does not rely upon any constitutional basis or precedent); Biden \& Ritch, supra note 83, at 5 (same).

247 If the legislative record in Rainbow Navigation v. Department of the Navy, 686 F. Supp. 354 (D.D.C. 1988), did not satisfy the government's criteria for a binding original interpretation, it would seem that few cases could. See supra notes 198-200 
Furthermore, the content of the Sofaer Doctrine's three factors is unclear - the Legal Adviser has not precisely indicated what is meant by each of the terms. ${ }^{248}$ How is one to know, for example, whether a particular Executive Branch statement was "clearly intended" to influence the Senate's consideration of a treaty? How does one measure whether an assertion was "generally understood" by the Legislature, especially if, in the ABM Treaty context, the Legal Adviser asserts that this test was not met by the 1972 discussions about future types of ABM systems? How extensively must the Senate "rely upon" an interpretation, especially when the votes of Senators in the ABM case do not seem to satisfy the Sofaer Doctrine?

In the absence of agreed-upon limitations, the Executive's asserted reinterpretation ability under the Sofaer Doctrine threatens both to disrupt political consideration of the merits of arms control policies and to undermine understanding of and support for the demands of international and constitutional law. There is accordingly a need to bring some order to the issue, to begin to apply to these difficult questions the general principles discussed in Part II. The discussion proceeds by considering each of the eight factors.

1. What did the Senate say about the particular issue when providing its advice and consent to the treaty?

The most reliable and accessible indication of the Senate's collective understanding and intention is usually given by the on-the-record explanations and debates. If key Senators (e.g., party leadership, committee chairs, floor managers $)^{249}$ paid careful attention to the specific matters contained in an original interpretation, and if the particular item seemed to be an important factor in senators' decisions about how to vote, then this understanding of the treaty should be more entrenched in the law and harder to alter subsequently.

It is not always easy to assess the degree of Senate notice based upon the Senate's words alone. Sometimes, of course, salient issues receive considerable overt attention, and relatively clear and formal expressions are placed directly into the resolution of ratification. At other times, however, important matters receive little explicit attention simply

and accompanying text.

${ }^{248}$ See The Doctrine or the Treaty?, N.Y. Times, May 5, 1988, at A30, col. 1 (discussing the three criteria of the Sofaer Doctrine). "Since it's hard to know what this mumbo-jumbo means, Presidents would be free to do with treaties as they wish." Id.

240 See Schwegmann Bros. v. Calvert Distillers Corp., 341 U.S. 384, 394 (1951) (in interpreting a statute, statements of legislative sponsors are more authoritative than the expressed fears of its opponents). 
because they are so very well accepted, and there is no controversy to incite debate. Often, the Senate registers its understandings relatively informally, with a comment in the Foreign Relations Committee hearings or markup, ${ }^{250}$ in the committee reports, ${ }^{251}$ or in floor debate, ${ }^{252}$ rather than in the resolution of ratification. Occasionally, it is even necessary to attempt to draw meaningful inferences from virtual silence. ${ }^{253}$ Whenever good faith analysis indicates that the Senate has formed a definite understanding on a point of interpretation, that understanding should be imported into the treaty as the law of the land.

On the other hand, if the point now in controversy was initially simply overlooked, attracting little attention, and no Senator seemed to care much about it, then it will be considered less entrenched. ${ }^{254}$ There can be no "magic number" defining how many Senate statements or votes are sufficient to establish a firm understanding, but given the limitations upon the Senate's ability to devote time and attention even to important matters, a very small number of explicit comments - particularly if they come from leading or expert Senators - should be pow-

250 Jurisdiction to review negotiated treaties is vested solely in the Foreign Relations Committee, but other committees, including the Armed Services Committee and the Intelligence Committee (as well as their counterparts in the House), also often assert an interest and the right to act in connection with a proposed agreement. See OLC Memorandum, supra note 83, at 5 n.9.

281 Compare United States v. Stuart, 57 U.S.L.W. 4263, 4267 n.7 (1989) (Brennan, J.) (it is "eminently reasonable" to consult committee reports in interpreting treaty language because "preratification reports [are not] kept under seal") with id. at 4269 (Scalia, J., concurring) (discussing the Senate's "unquestioned power" to attach conditions to the resolution of ratification: "[I]t is a far cry from all of this to say that the meaning of a treaty can be determined . . . by legislative history of the sort that we have become accustomed to using for the purpose of determining the meaning of domestic legislation.") and Hirschey v. Federal Energy Regulatory Comm'n, 777 F.2d 1, 6-8 (D.C. Gir. 1985) (Scalia, J., concurring) (improper to rely upon committee reports for details of legislative intention because reports are drafted by staff and are not voted upon by legislators).

${ }^{252}$ See Stuart, 57 U.S.L.W. at 4267 (referring to floor debate in discussing the meaning of a treaty provision); see also Chrysler Corp. v. Brown, 441 U.S. 281, 311 (1979) (scrutinizing sponsor's floor statements in colloquy with other legislators, and statements by several other Senators in order to ascertain intended interpretation).

${ }^{263}$ Under the Sofaer Doctrine, any implicit, unstated Senate understandings would be less reliable and more susceptible to subsequent reinterpretation since the Senate did not overtly declare its conditions. But if the Senate were silent on a point simply because a particular understanding was so widely shared and so generally accepted that no further comment was deemed necessary, then the Sofaer Doctrine would have the perverse effect of jeopardizing the most basic points of consensus. See Biden \& Ritch, supra note 83, at 5-6.

${ }_{284}$ See, e.g., Weinberger v. Rossi, 456 U.S. 25, 35 (1982) (one isolated remark by a single Senator is insufficient to establish congressional intent); Joint Hearings, supra note 1 , at 88 (statement of Professor Louis Henkin) ("We have to distinguish, however, between an understanding in some essential respect and matters which are of little significance. The Senate may not have any understanding about some matter which the Senate does not consider important."). 
erful evidence. ${ }^{255}$

2. What was said to the Senate, creating an understanding of the treaty, prior to ratification?

Statements by Executive Branch witnesses, representing the negotiating delegation and drawing upon the confidential record of exchanges with the other nation, can be especially compelling in generating a senatorial understanding or interpretation. Where these presentations are relatively clear, consistent, and voluminous, the interpretation they present will be more entrenched and more difficult for subsequent Presidents to dislodge. ${ }^{268}$

Similarly, the more high-ranking and knowledgeable the spokespersons, and the more well-considered their presentations, the more they could reasonably be deemed to have had a substantial impact upon the legislators' understanding, and the more durable this original interpretation will be. ${ }^{287}$ The official section-by-section analysis of the

${ }^{258}$ See Joint Hearings, supra note 1, at 87 (statement of Professor Louis Henkin). Professor Henkin noted:

The views of individual Senators have to be considered in the context of the whole deliberative process of the Senate. The question is what was the understanding of the Senate, as a whole, in giving its consent.

It is difficult to disentangle the views of a particular Senator from a general Senate understanding. Often it is not possible to determine the understanding with certainty and clarity. But where several statements are made and there is general acceptance of their tenor, that is the Senate understanding.

Id.; see also id. at 162 (statement of Senator Biden) (noting that only a few senators typically acquire expertise on a particular topic, and others will tend to defer to their statements and judgments); Finney, A Historical Perspective, in THE ABM TREaTy: To DEFEND OR NOT To DefEND?, supra note 62 , at 42 ("it is probably fair to say that only a half dozen senators fully understood the provisions of the [ABM] Treaty dealing with future development of ABM systems").

${ }^{268}$ See Sofaer, $A B M T$ Reports, supra note 77, at S6673; cf. O'Connor v. United States, 479 U.S. 27, 32-33 (1986) (citing consistency of Executive's interpretation of Panama Canal Treaty as a factor entitled to great weight); United States v. Vogel Fertilizer Co., 455 U.S. 16, 31 (1982) (in interpreting legislation, court attaches "great value" to agency representations to Congress when the agency administrators participated in drafting the legislation and made their views known to Congress during committee hearings). But see Austasia Intermodal Lines, Ltd. v. Federal Maritime Comm'n, 580 F.2d 642, 645-46 (D.C. Cir. 1978) (testimony at hearings should not be accorded undue weight in interpreting statutes, since the views of witnesses may not be the same as views of legislators).

${ }^{287}$ See, e.g., NATO Defense Hearings, supra note 76, vol. 1 at 28 (Senator Nunn questioning Secretary of Defense Frank Carlucci to ascertain that he is "an authoritative witness" and "speaking for the President of the United States and for the administration"); 133 CoNG. REC. S2978 (daily ed. Mar. 11, 1987) (statement of Senator Nunn) (noting that weight should be given to the 1972 John Foster testimony regarding the ABM Treaty, even though he was not a member of the negotiating delegation, because he was a presidential appointee in the Department of Defense, the highest- 
treaty, provided in the Secretary of State's Letter of Submittal, will be a most authoritative source, ${ }^{258}$ and special weight will be given to prepared statements, or to written responses to Senate questions, where the entire government is presumed to have collaborated on the reply. ${ }^{259}$

However, less formal statements may also have had an impact on the Senate. Testimony from experts outside the administration may contribute to the Senate's understandings, and non-testimonial statements by administration spokespersons (in public speeches, press conferences, and the like) may have an impact, as the public record helps mold Senate understanding.

In keeping with the notion that key Executive Branch influences cannot subsequently be denigrated, it will be more legitimate for a subsequent administration to rebut an original interpretation when conditions suggest that the earlier statements did not create a common Senate understanding: 1) if the issue was covered only sparingly and obliquely; 2) if administration witnesses were inconsistent on a particular point; or 3 ) if the original interpretation was sponsored only by relatively junior, or relatively uninformed authorities, especially when speaking "off the cuff" (as in impromptu oral responses to spontaneous questions), rather than pursuant to detailed, coordinated executive branch instructions. ${ }^{260}$

In the same vein, any "secret agreements" - understandings between the two negotiating delegations or between the two heads of state, which are not communicated to the Senate - will have no impact upon domestic United States law. The Senate cannot have any understanding of, and cannot express any consent for, the terms of a hidden deal that was never displayed for its cognizance.

ranking technical official there, and the third-ranking civilian).

${ }^{258}$ In its 1988 report on the INF Treaty, the Senate Foreign Relations Committee expressly noted that the Secretary's article-by-article analysis of the provisions of the Treaty "constitutes a formal Executive representation as to the meaning of the INF Treaty and the obligations to be assumed by the United States under the Treaty." INFT REPORT, supra note 8, at 109. In its 1979 report on the SALT II Treaty, the Senate Foreign Relations Committee determined that "Executive Branch comments, in general, adequately describe and explain the agreement provisions," and the committee's own explanatory comments were added only where further elaboration was desirable. SFRC SALT II RePORT, supra note 35, at 319.

${ }^{258}$ Cf. Joint Hearings, supra note 1, at 546 (letter from Professor Richard B. Bilder) (stating that in interpreting a negotiating record to clarify ambiguities in treaty text, a tribunal will accord more weight to the written or oral accords reached by the heads of the delegations than to the work of lower-ranking members).

${ }^{280}$ See Sofaer, ABMT Reports, supra note 77, at S6,673. 
3. What has been the attitude of the other party to the competing interpretations of the treaty?

Neither state party, of course, holds a veto over the domestic political processes in the other nation. Nonetheless, the views of the other party may not be ignored. Where the negotiating partner is ambivalent, or even agreeable, a reinterpretation will be more viable than when the other party insists on maintenance of the original understandings. ${ }^{261}$ In some instances, even the views of non-parties who are implicated in the treaty regime may also be relevant.

4. How much support is there in the treaty text and record for the two interpretations?

If the treaty text, the negotiating record, and the legislative history are all congruent, then a new interpretation will be harder to sustain. However, if the documentation is ambiguous, or a fortiori, if the original interpretation is now appreciated as an incorrect, aberrational reading of the treaty and its record, then a reinterpretation is more tolerable.

5. What is the record of "subsequent practice" of the treaty parties?

How - and for how long - have the parties operated under the original interpretation, and what did they say at the time about their legal obligations to do so? If the parties' behavior has been consistent, if they have acted out of a sense of legal commitment (rather than simple habit or comity), and if substantial "reliance" interests have built up, then the original interpretation is more entrenched. ${ }^{262}$ To the extent

${ }^{261}$ See, e.g., Joint Hearings, supra note 1, at 79 (statement of Professor Gordon Brewster Baldwin) (arguing that the line between an interpretation and an alteration of a treaty is not sharp; the party in the best position to make that judgment regarding the ABM Treaty would be the Soviet Union); Rhinelander, Reagan's "Exotic" Interpretation of the ABM Treaty, ARMS CoNTROL TODAY, Oct. 1985, at 3, 6 (arguing that if there were any legitimate doubt about the correct interpretation of the ABM Treaty, the best approach would be to ask the Soviet Union to reaffirm the traditional interpretation; if the Soviets were unwilling, then the reinterpretation would be more justified); see also O'Connor v. United States, 479 U.S. 27, 33 (1986) (citing Panama's failure to challenge the application of the United States' view as grounds to support the United States' interpretation of the tax provisions of the Panama Canal Treaty); Air France v. Saks, 470 U.S. 392, 404 (1985) (in interpreting the Warsaw Convention on air travel, the Court finds "the opinions of our sister signatories to be entitled to considerable weight" (quoting Benjamins v. British European Airways, 572 F.2d 913, 919 (2d Cir. 1978), cert. denied, 439 U.S. 1114 (1979))).

${ }^{262}$ See O'Connor, 479 U.S. at 33 ("The course of conduct of parties to an inter- 
that the Senate, the public, the other party, or other relevant actors have aligned their affairs in reliance upon the continuing viability of the original interpretation or understanding, it will be harder to alter. ${ }^{263}$ Conversely, where the patterns of implementation are ambivalent, and the costs of reinterpretation are lower, it will be more feasible to promote a change. ${ }^{284}$

\section{How different is the new interpretation from the old?}

In general, the more substantial the proferred change, the more appropriate it would be to implement it via treaty amendment or statute rather than via reinterpretation. ${ }^{265}$ Lesser, non-central modifications are more tolerable, as allowance is made for incremental growth in the treaty regime.

7. Does the new interpretation purport to create new obligations, or to release old ones?

Although the distinction between affirmative and negative obligations may be a slippery one, there is in international law a principle that limitations on the autonomy of a nation are not to be presumed. ${ }^{268}$ Therefore, in general, it will be harder to implement new constraints via a reinterpretation, and it may be somewhat easier to relax contested obligations by that device. ${ }^{287}$

national agreement, like the course of conduct of parties to any contract, is evidence of its meaning.").

${ }^{203}$ See Case Concerning the Temple of Preah Vihear, 1962 I.C.J. 6, 22 (holding that Thailand's acquiescence over many years regarding a borderline established by a map drawing is binding).

${ }^{264}$ See Chevron U.S.A. v. Natural Resources Defense Council, 467 U.S. 837, 863 (1984) (where statute and legislative history are ambiguous, EPA has authority to interpret statute flexibly, including power to change its interpretation by implementing regulations from time to time); Red Lion Broadcasting Co. v. FCC, 395 U.S. 367, 38082 (1969) (where agency has given consistent interpretation of statute, and Congress has ratified that interpretation with subsequent legislation, a court will give that view great weight); McCaughn y. Hershey Chocolate Co., 283 U.S. 488, 492 (1931) (administrative agency's consistent construction of a statute over many years will not be disturbed judicially except for reasons of great weight).

${ }^{265}$ See Joint Hearings, supra note 1, at 102-03 (statement of Professor Henkin). ${ }^{268}$ See Case of the S.S. "Lotus" (French Republic v. Turkish Republic), 1927 P.C.I.J. (Ser. A) No. 9, at 18 (Sept. 7).

${ }^{267}$ Cf. Factor v. Laubenheimer, 290 U.S. 276, 293 (1933) (rejecting a narrow reading of an extradition treaty that would have confined it to acts that are criminal in both countries, saying that, generally, a more liberal construction of a treaty, enlarging the rights which may be claimed under it, is preferred). 
8. Are there any changed circumstances that affect the treaty?

The doctrine of rebus sic stantibus ${ }^{268}$ suggests that a fundamental, unforeseen alteration in the relevant factual basis for a treaty may be a valid reason for non-application of its terms. Even short of complete negation of the treaty, circumstances may have changed in ways that arguably could help justify a new interpretation. ${ }^{\mathbf{2 6 \theta}}$

In sum, these eight factors define a method for assessing the legitimacy of a treaty reinterpretation whenever the Executive purports to deviate from an original understanding of the meaning of the agreement. If, on balance, one concludes that the original interpretation has - via the operation of these eight factors - become "entrenched" in domestic law, then the President may not unilaterally depart from it. On the other hand, if these factors do not suggest that the original understanding has risen to the level of "law of the land," then there was no established interpretation to begin with. The President may then proffer one (an act of original interpretation, not reinterpretation), and the other branches of government will proceed, as they deem fit, to accord it more or less deference.

\section{ReCommendations and Gonclusions}

\section{A. Unilateral Modifications in the Meaning of United States Treaty Obligations Should Not Be Undertaken Easily or Often}

This Article has argued that there is no such thing in American law as a power of treaty reinterpretation - that once the meaning of an international agreement is established, the President has no constitutional authority unilaterally to alter it. The underlying question is whether the "original interpretation" has become entrenched in law. The history of a particular treaty constitutes a complex factual record for applying and weighing these eight factors to answer that question. But at least the legal effect is straightforward: if at the time of making the treaty, the Senate did have a particular understanding of it, the

${ }^{268}$ This doctrine posits that the basic international law doctrine of "pacta sunt servanda" ("treaties should be honored") will apply only "rebus sic stantibus" ("so long as circumstances stay the same.").

268 See Vienna Convention, supra note 2, art. 62; REsTATEMENT, supra note 2, $\S 336$. The doctrine of rebus sic stantibus is an exceptional remedy, to be applied only when important changes have frustrated the operation of the treaty. See RestateMENT, supra note 2, §336, comment a; see also 1987 SFRC REPORT, supra note 4, at 102 (minority argues that fundamental circumstances have changed sufficiently - Soviet violations of arms control treaties, failure to conclude a treaty providing for deep cuts in strategic offensive arms, and the emergence of SDI technology - so as to warrant amending or terminating the ABM Treaty). 
President can make the treaty only subject to that understanding and it can be changed only by a subsequent lawmaking activity that is of equal stature under the Constitution.

On the other hand, if the Senate did not, at the moment of giving its advice and consent, have a crystallized particular understanding on point, then there is a gap in the law. Any subsequent executive action will be an "interpretation," not a "reinterpretation," and will be accorded the customary (that is, partial) deference by the other branches. Under these circumstances, the Executive's interpretation will not be binding law upon the United States or the other party, and it may be freely altered again in the future.

This conclusion does not require any loss of flexibility or adaptability of the treaty power. The eight factors for entrenching an understanding will not be easy to satisfy, and the meaning of a treaty, like the meaning of the Constitution or a statute, remains free to evolve over time as circumstances warrant. Even when the Executive has sponsored testimony that helps elucidate the meaning of the treaty during the advice and consent period - presentations that ordinarily carry great weight in entrenching a specific meaning for the treaty - there may still be scope for subsequent reversal if, for example, the Senate ignored or resisted the original interpretation, or if it was inconsistently or unpersuasively presented.

At the same time, it should be emphasized that any revised executive interpretations or other modifications in United States treaty obligations should be exceedingly rare. The shared legislative-executive role in creating treaties requires that the Senate's participation be meaningful, and that, in turn, requires that Executive Branch representations be reliable. ${ }^{270}$ The need for stability and predictability - both in internal political debates and for the conduct of United States foreign relations -argues that "entangling alliances" should be created with care, adhered to with precision, and, when the occasion demands, changed in an overt, direct fashion, with full participation of the Senate and the President (as well as the other party), rather than by a sudden

270 There is also an international dimension to the concern for the reliability of authoritative executive branch statements to the Senate. That is, it is strongly in the United States' interest for our senior spokespersons to be appreciated as important commentators on the meaning of treaties: this image will enhance the prestige of the United States, and the power of United States officials to sponsor definitive interpretations of a treaty, so they can be used to advantage in future interpretation disputes with other parties. See Joint Hearings, supra note 1, at 60 (statement of Senator Nunn); $c f$. HFCA ABM Hearings, supra note 56, at 53 (comments of Ambassador Ralph Earle) ("Any treaty can be reinterpreted to suit one's own desires, but it certainly makes your negotiating partner leery of negotiating any decent agreement with you in the future."). 
unilateral reinterpretation. ${ }^{271}$

The Sofaer Doctrine would empower the Executive to shed the effects of prior statements unless impossibly strict conditions were met. This simply gives the President too much leeway to frustrate the Senate's constitutional responsibility. Indeed, if neither the ABM Treaty ${ }^{272}$ nor the Rainbow Navigation ${ }^{273}$ case qualifies under the Sofaer Doctrine as having a sufficiently entrenched original interpretation, it is difficult to see how any realistic treaty-making record could withstand subsequent executive revisionism.

The bottom line is that the Constitution mandates that the Senate play a role in creating international obligations for the United States. Moreover, because the Executive negotiates the text of the treaty, the Senate must be able to depend upon authoritative executive representations in order to give meaningful advice and consent. To permit the President to avoid the consequences of interpretative assertions advanced on the government's behalf, and to field a new interpretation with so little regard for the record of Senate participation and reliance is tantamount to a classic "bait and switch."

\section{B. The Senate Has A Legitimate Stake in Reasserting Its Role in Creating Treaties}

To a large extent, the problem of reinterpretation, in the case of both the ABM Treaty and the INF Treaty, was thrust upon the Congress, not instigated by it. The Executive Branch precipitated the confrontation by propounding the Sofaer Doctrine to justify the attempted modification of the ABM Treaty, and by reasserting the Doctrine when the issue resurfaced in the context of the INF Treaty. ${ }^{274}$ Effective judicial review of the issue seemed unlikely because, even with the precedent set by Rainbow Navigation, ${ }^{275}$ the hurdles of standing, and the political question doctrine probably preclude a court from resolving the

${ }^{271}$ See Morrison, supra note 77, at 1752 (quoting Senator Kassebaum that if modification of the ABM Treaty is necessary, reinterpretation "is the wrong way to do it," and formal renegotiation should be undertaken).

272 See supra notes 53-72 and accompanying text.

${ }^{273}$ See supra notes 191-201 and accompanying text.

274 See INFT REPORT, supra note 8, at 87-89 (Senators considering the INF Treaty dealt with the reinterpretation question "by necessity, not by choice"). In the view of the Legal Adviser, it is the Senate that was at fault, for failing to be sufficiently clear in the resolution of ratification regarding the precise terms upon which it was consenting to the ABM Treaty. See Sofaer, ABMT Reports, supra note 77, at S6674. In the OLC Memorandum, supra note 83, at 2, the Department of Justice advised that the ratification record "cannot be ignored in the interpretation process," but proceeded to accord it very little weight.

${ }^{275}$ Rainbow Navigation, Inc. v. United States 686 F. Supp. 354 (D.D.C. 1988). 
merits of these sensitive national security matters. ${ }^{276}$ Accordingly, Congress was well within its mandate in tackling the reinterpretation problem and in seeking a method to resolve it. Congress's longstanding special interest in arms control matters - where vital issues of national security are at stake - made it especially important that the Legislature not cede undue authority to the Executive Branch.

Ordinary legislation probably could have provided a suitable battleground for resolving this question. ${ }^{277}$ Congress could have enacted a statute (including overriding a presidential veto) explicitly forbidding actions inconsistent with the Senate's interpretation of the ABM Treaty, the INF Treaty, or any other international agreement. ${ }^{278}$ The limitations on SDI activities that Congress implanted into the Department of Defense authorization legislation provide a partial illustration of this technique, effectively (though indirectly) prohibiting funds for any purposes that violate the original interpretation of the $A B M$ Treaty. ${ }^{278}$

From one perspective, the recourse to ordinary legislation might actually be the superior method for entrenching a congressional interpretation, because it does not complicate the treaty-making process or require the assent of other parties. In the context of the ABM Treaty, where the initial phase of the Treaty's lifespan has long since passed, it may be Congress's only remaining alternative.

In the case of the INF Treaty, however, direct work on the resolution of ratification was available and the Senate was fully justified in taking advantage of it. That strategy, however, has created a lingering anomaly yet to be resolved. That is, the terms of the Biden Condition reach only the INF Treaty, not any of its predecessors or successors. What, then, is the regime applicable to the ABM Treaty and to hundreds of other existing treaties for which no similar language was included in the appropriate resolution of ratification? Moreover, must the language of the Condition now become a standard part of the boiler-

${ }^{278}$ See supra notes $189-90$.

${ }^{277}$ See Cutler, Keeping the ABM Treaty Alive: What Congress Can Do, ARMS Control ToDAY, Apr. 1987, at 10, 11 (maintaining that it would be constitutional for Congress, by statute, to require the Executive not to engage in any actions that would violate a stated interpretation of a treaty).

278 The Senate considered the option of dealing with the ABM Treaty interpretation controversy by ordinary legislation. However, many felt that the issue was of constitutional scope, rather than being confined to the question of which particular SDI experiments would be authorized. See Joint Hearings, supra note 1, at 3 (statement of Senator Biden) ("One technique, that of legislating compliance with the treaty's correct interpretation, could be effective on a policy level, but would fail to meet the constitutional issue head-on.").

${ }^{279}$ See supra note 80 and accompanying text. 
plate used in the Senate's consent to all future agreements? If the view presented in this Article is correct, the solution to this problem lies in the fact that the Biden Condition simply states a truism of international and constitutional law. It is, therefore, legally redundant as a policy device, for even without its language in the resolution of ratification, the principles it espouses would be read into the treaty by the force of the Constitution. ${ }^{280}$ At the same time, however, the Biden Condition may have been politically necessary - a reassertion of enduring principles that had recently been called into question by the executive branch.

In addition to its utility in reaffirming the respective roles of Senate and Executive in treaty ratification, the process of attempting to identify and highlight "interpretation" questions may be salutary for the process of effectuating a treaty. Regarding the INF Treaty, for example, the Senate labored mightily to ensure that it understood and fully supported the Executive's work. This resulted in a high degree of probing of the interstices of the agreement, including an exceptionally thorough hearing process. Partly as a result of intensive Senate scrutiny, various latent ambiguities were identified and potential future problems were anticipated and satisfactorily resolved. For example, the question of the applicability of the agreement to "future types" of intermediate range weapons had not been explicitly resolved in the treaty text, but upon senatorial prompting, representatives of the United States and the Soviet Union were able to confirm their joint understanding that such systems were included within the scope of the Treaty. ${ }^{281}$

Finally, it is also important to note that the conclusions reached in this Article do not resolve the factual or substantive questions of $\mathrm{ABM}$ Treaty interpretation that opened this issue in the first place. That is, even if one agrees that the Sofaer Doctrine is overbroad and too permissive of reinterpretations, one could still advocate the broad interpretation of the ABM Treaty favored by the Reagan administration by

${ }^{280}$ The Foreign Relations Committee noted that in this respect its proviso may have been unnecessary, but members felt compelled to act in a fashion that would clearly signal nonacquiescence in the Sofaer Doctrine. See INFT REPORT, supra note 8, at 97; see also Smith, supra note 5, at A17, col. 6 (quoting Paul C. Warnke) ("It has always been the law that what the executive branch says to the Senate in presenting a treaty for advice and consent is legally binding. Now you can say it again, but that still won't change anything and it would not prevent some subsequent group of miscreants from violating the law.").

${ }^{281}$ See Oberdorfer, U.S.-Soviet Terms Set for Treaty, Wash. Post, May 13, 1988, at A1, col. 6; INF Treaty Resolution of Ratification, condition 2, 134 CoNG. REC. S6937 (daily ed. May 27, 1988) (requiring President to obtain official Soviet agreement that diplomatic notes exchanged on May 12, 1988 regarding "future technologies" weapons and other details shall have the same legal force and effect as the Treaty itself); see also supra notes 59-61 and accompanying text. 
using the eight factors identified above to examine the record. One could argue, for example, that the 1972 testimony supporting the original interpretation was too ambiguous or too contradictory to entrench any durable Senate understanding. ${ }^{282}$ As the Foreign Relations Committee noted in evaluating the Biden Condition, the principle that authoritative Executive Branch statements must be legally binding is logically separable from the application of that principle in evaluating any particular case. ${ }^{283}$

\section{G. The Process of Creating National Security Treaties Should Not Be Burdened Any More Than It Already Is}

The United States has experienced grave difficulties in bringing the national security treaties that it negotiates into force. ${ }^{284}$ The INF Treaty (which, despite overwhelming domestic support, required some six months between signature and ratification) was the first significant arms control agreement to win Senate advice and consent since the Biological Weapons Convention ${ }^{285}$ and the Geneva Protocol ${ }^{286}$ in 1975. In the interim, three major bilateral accords (the SALT II Treaty, ${ }^{287}$ the Threshold Test Ban Treaty, ${ }^{288}$ and the Peaceful Nuclear Explosions Treaty) ${ }^{289}$ were negotiated and signed by the United States and USSR, but have languished without a Senate vote.

This poor record of ratification calls into question the reliability of the United States as a negotiating partner and jeopardizes its ability to create future agreements. ${ }^{200}$ The success of the INF Treaty may be a

${ }^{282}$ See Joint Hearings, supra note 1, at 449 (statement of Sen. Hollings).

283 See INFT REPORT, supra note 8, at 90, 106; see also Joint Hearings, supra note 1 , at 55 (statement of Senator Nunn) (the debate over the reinterpretation of the ABM Treaty should not be cast in terms of whether one is for or against the Treaty itself).

284 The United States's unwillingness to ratify the Versailles Treaty and join the League of Nations after World War I has been cited often as a major cause of the failure of the interwar security structure. See, e.g., F. NoRTHEDge, The League of Nations: ITs Life AND Tmes, 1920-1946, at 283-92 (1986) (discussing the causes of the failure of the League).

${ }^{285}$ Biological Weapons Convention, supra note 21.

${ }^{288}$ Geneva Protocol, supra note 12.

${ }^{287}$ SALT II Treaty, supra note 51.

${ }^{288}$ Treaty on the Limitation of Underground Nuclear Weapon Tests, July 3, 1974, United States-USSR, 13 I.L.M. 906 [hereinafter TTBT] (signed but not ratified).

${ }^{289}$ Treaty on Underground Nuclear Explosions for Peaceful Purposes, May 28, 1976, United States-USSR, 15 I.L.M. 891 [hereinafter PNET] (signed but not ratified). Like the TTBT, the PNET has lingered on the calendar of the Senate Foreign Relations Committee, as Presidents have failed to push for ratification. See ACDA TREATY BoOK, supra note 14, at 171-72.

${ }^{290}$ See, e.g., R. EINHORN, Negotiating FROM Strength: LEVERAGE IN U.S.- 
harbinger of a more responsible future, but in the interim, pressing concerns about the process of domestic evaluation of negotiated treaties remain unaddressed, and several specific recommendations seem in order.

First, the Senate should not become accustomed to examining the details of the classified negotiating record leading to arms control agreements. These records are voluminous and cumbersome, and the benefits of exploring them are not usually as illuminating as the task is burdensome. More importantly, the contents of the negotiating record - reflecting exchanges between the United States Executive and the Soviet counterpart - do not affect the internal law of the United States. Any secret deals made or interpretations exchanged during the negotiations are not properly before the Senate, unless the Executive formally brings them forward. ${ }^{201}$

Moreover, exposure of the negotiating record carries an inherent cost of jeopardizing the confidentiality and frankness of the negotiating process. Delegation members' "memcons" are their official reports to their superiors, and those reports would probably become less direct, and less useful, if the authors had to write with one eye on a future congressional audience. ${ }^{282}$ The Foreign Relations Committee should therefore be applauded for its decision to distance itself from the bulk of the negotiating record in the INF Treaty case, and this decision should serve to reaffirm the privacy of the negotiating process. ${ }^{293}$

Second, the Senate and the Executive should not use the evaluation of one treaty as the occasion to refight the battles of another treaty.

Soviet ARMS Control Negotiations 71-75 (1985) (Soviet negotiating behavior is affected by their perceptions of United States resolve, coherence and consistency, as well as by the President's ability to muster domestic support).

281 See INFT REPORT, supra note 8, at 100-01 ("[B]y seeking possession of the myriad internal executive memoranda comprising the 'negotiating record,' the Senate would impose upon itself a considerable task with no clear purpose.").

202 See Joint Hearings, supra note 1, at 94 (statement of Professor Gordon Brewster Baldwin) (claiming that American and foreign diplomats would be inhibited if they knew that the negotiating record would later be made public); $i d$. at 98 (statement of Professor Louis Henkin) (stating that negotiating records of most treaties are made public, but usually only after 50 or 60 years, when damage to important interests is less likely).

This point, however, may already have been irretrievably lost. The ABM Treaty reinterpretation controversy has led to the premature declassification and public release of so much of the negotiating record that future negotiators will have to assume the high likelihood of similar future exposure. See, e.g., 133 CoNG. REc. S6809 (daily ed. May 20, 1987) (report by Senator Nunn) (examining Sofaer's analysis of the ABM Treaty negotiating record); Sofaer, $A B M T$ Reports, supra note 77, at S6640-63 (reprinting material from the negotiating record of the ABM Treaty).

${ }^{283}$ See INFT REPORT, supra note 8, at 100-01; see also Joint Hearings, supra note 1, at 33-34 (colloquy between Senators Biden and Wilson regarding the advisability of declassifying the negotiating record of the ABM Treaty). 
That is, the process of providing advice and consent to the INF Treaty during the spring of 1988 was inevitably complicated by its relationship to the reinterpretation question of the ABM Treaty. Although a temporary resolution was eventually reached, and the INF Treaty was ratified, it is distressing that a document of such great importance could not be evaluated solely on its own terms. The INF Treaty, like most arms control agreements, is so significant and so complex that it deserved the Senate's focussed attention. A new arms control agreement should not be held hostage while the Congress and the Executive spar on other matters. Political linkage of some sort is perhaps inevitable, but it should be minimized in favor of the prompt and thorough assessment of the pending treaty.

Third, internal United States interpretations of its domestic and international law obligations ordinarily ought not to be officially communicated to the other party to the treaty. Common executive-legislative interpretations, of course, will be of interest to the other state, ${ }^{284}$ but they are not part of the international law created by the treaty. It simply confuses matters to convey these interpretations officially, according the Soviet Union the occasion to protest, disagree, or otherwise complicate affairs. In the past, the Senate has acted soundly in this area, deciding during the INF Treaty process, for example, to treat the Biden Condition as a Category I proviso, thus not requiring notification of, or acceptance by, the Soviet Union. ${ }^{295}$

\section{In Establishing an Authoritative Interpretation of a Treaty for} Purposes of Domestic Law, the United States Should Not Overlook the Possibility of Authoritative International Adjudication

The final suggestion of this Article is a counterpoint to its main theme, and sounds a warning about the potential of a different form of danger latent in overly restrictive treaty interpretation. As noted, treaties have implications for both domestic and international law, and

294 The Soviet Union regularly monitors the progress of bilateral treaties through the process of Senate advice and consent by sending observers to committee hearings. See Joint Hearings, supra note 1, at 59-60 (statement of Senator Nunn) (Senators Goldwater and Jackson had noted on the record the presence of a Soviet official throughout the extensive discussion of the ABM Treaty during the Senate Armed Services Committee hearings in 1972). But see id. at 128 (statement of Abraham D. Sofaer, State Department Legal Adviser) (noting that the United States regards itself as having no duty to monitor other nations' ratification processes; it would be cumbersome to do so, and we could never ensure that other states were reciprocating); Sofaer,

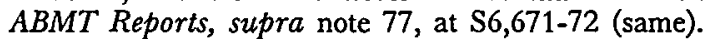

${ }^{205}$ See INFT REPORT, supra note 8, at 99-100; see also supra note 203 and accompanying text (discussing the typology of conditions outlined in the RESTATEMENT, supra note 2 , § 314). 
these implications may not be congruent. In Part II, we saw that for municipal purposes, the official United States interpretation is dispositive: any understandings or interpretations that are read into the treaty at the time of ratification will be law of the land, binding upon all three branches, and subject to change only through the law making process.

For international purposes, however, the United States does not have the last word. Although no arms control treaties currently provide for independent international adjudication, ${ }^{286}$ other types of important international agreements do commit the United States to binding arbitration $^{297}$ or to other neutral adjudication. ${ }^{288}$ In those instances, when presented with an issue of treaty interpretation, the international tribunal would weigh the competing views offered by the parties, and determine authoritatively what the treaty means in the international context.

If the ruling goes against the United States, this country will have the power (although not the "right") to decide whether to comply with the order of the international proceeding and take actions necessary to conform to the new authoritative position, or, conversely, to stand in violation of it. This choice may be a difficult one, and many factors will influence the decision. But it would not serve United States interests to be preemptively locked in to the position that the United States will never change its position or interpretation without amending the treaty.

The Biden Condition to the INF Treaty resolution of ratification is unclear on this point. It provides that "the United States shall not agree to or adopt an interpretation different from [the current executive-legislative understanding of the treaty] except pursuant to Senate advice and consent to a subsequent treaty or protocol, or the enactment of a statute."289 Under this language, could the United States reliably

${ }^{296}$ The INF Treaty, supra note 8 , art. XIII, at 1468 , creates a Special Verification Commission, and the ABM Treaty, supra note 7, art. XIII, at 3444, calls for the establishment of a Standing Consultative Commission, both of which are empowered to discuss compliance questions and other matters. But these institutions are not independent tribunals; they are essentially negotiating fora under the control of the parties to the treaty and are able to resolve matters only by consensus.

297 Recourse to binding arbitration has become increasingly important as a mechanism for resolving international disputes. For example, United States and Iranian claims arising from the seizure of American hostages in Teheran and the freezing of Iranian assets in the United States were submitted to a claims commission for settlement. See Dames \& Moore v. Regan, 453 U.S. 654, 665 (1981).

${ }^{208}$ Although the United States withdrew from participation in the "compulsory jurisdiction" of the International Court of Justice in 1985, the Reagan Administration recently indicated a greater interest in agreeing with the Soviet Union to utilize the International Court more frequently - at least in cases that do not involve security considerations. See Oberdorfer, U.S. Now Urges Greater Use of World Court, Wash. Post, Oct. 7, 1988, at A34, col. 1.

${ }_{299} 134$ CoNG. Rec. S6937 (daily ed. May 27, 1988); see also notes 97-106 and 
submit disputes to binding international adjudication? Does the language require that, whenever the United States's interpretation is rejected, this country will resist the authoritative international interpretation, unless the other party agrees to renegotiate the treaty (and give up in diplomacy a victory it just won in litigation) or new domestic United States law is created to effectuate the new ruling?

This type of unilateralism in foreign affairs is not a sound device for aiding the establishment of a viable network of international law and order. The Biden Condition, on its face, does not require this hostility toward international law, but neither does it seem to contemplate any expansion of the sphere within which international adjudication can be effective. Perhaps any such developments are a long way off, at least in the sphere of arms control and national security, but it seems appropriate to note that over-vigilance in entrenching a particular interpretation into United States law may not be fully consistent with a willingness to join the international community in enhancing the role of binding international dispute resolution.

\section{E. Summation}

We may end this discussion by restating the obvious point that the authority to reinterpret treaties would be a powerful tool in the hands of the Executive, allowing a President to revise settled treaty law unilaterally. Such authority is, however, alien to the Constitution, in which the separation of powers guaranties Senate participation in the establishment, as well as in the amendment, of treaty law.

It may not be easy to determine, in any particular case, whether the Senate has in fact formulated and "entrenched" an understanding or interpretation of a treaty, but the eight factors outlined above are designed to guide that inquiry. One of the more important points is that Executive Branch testimony should be treated as particularly compelling evidence of what was integral to creating an enduring legislative understanding. The negotiators of the treaty authoritatively offer interpretations which can inspire Senate reliance and thereby become binding, even if the Senate does not write them into the resolution of ratification, and even if the Senate's acceptance of the Executive's interpretation must be inferred from virtual silence.

What is fundamental is that the fact of the Senate's advice and conditional consent create the terms upon which the Constitution allows the treaty to be made. These understandings cannot be divorced 
from the text of the agreement - they establish the binding domestic law of the land. Respect for the constitutional scheme of separation of powers, and appreciation for the standards of international law, therefore, compel stark limitations upon Executive Branch treaty reinterpretations. 
